UNIVERSIDADE DE SÃO PAULO

FACULDADE DE ECONOMIA, ADMINISTRAÇÃO E CONTABILIDADE DE RIBEIRÃO PRETO

DEPARTAMENTO DE ADMINISTRAÇÃO

PROGRAMA DE PÓS-GRADUAÇÃO EM ADMINISTRAÇÃO DE ORGANIZAÇÕES

\title{
BEATRIZ WILLEMSENS
}

Competências socioemocionais: efeitos do contexto escolar da religiosidade e mediação sobre o desempenho acadêmico.

ORIENTADOR: PROF. DR. MÁRCIO MATTOS BORGES DE OLIVEIRA 
Prof. Dr. Marco Antonio Zago

Reitor da Universidade de São Paulo

Prof. Dr. Dante Pinheiro Martinelli

Diretor da Faculdade de Economia, Administração e Contabilidade de Ribeirão Preto

Profa. Dra. Sônia Valle Walter Borges de Oliveira Chefe do Departamento de Administração 


\section{BEATRIZ WILLEMSENS}

Competências socioemocionais: efeitos do contexto escolar da religiosidade e mediação sobre o desempenho acadêmico.

Tese apresentada ao Programa de Pós-Graduação em Administração de Organizações da Faculdade de Economia, Administração e Contabilidade de Ribeirão Preto da Universidade de São Paulo, para obtenção do título de Doutora em Ciências. Versão Corrigida. A original encontra-se disponível na FEA-RP/USP.

ORIENTADOR: PROF. DR. MÁRCIO MATTOS BORGES DE OLIVEIRA

\section{RIBEIRÃO PRETO}


Autorizo a reprodução e divulgação total ou parcial deste trabalho, por qualquer meio convencional ou eletrônico, para fim de estudo e pesquisa, desde que citada a fonte.

Willemsens, Beatriz

Competências socioemocionais: efeitos do contexto escolar da religiosidade e mediação sobre o desempenho acadêmico. Ribeirão Preto, 2016.

120 p: il; 30 com.

Tese de Doutorado apresentada à Faculdade de Economia, Administração e Contabilidade de Ribeirão Preto/USP.

Área de concentração: Administração de Organizações.

Orientador: Oliveira, Márcio Mattos Borges de

1. Habilidades socioemocionais 2. Desempenho acadêmico

3. Contexto escolar da religiosidade 4. Análise de mediação 
Nome: WILLEMSENS, Beatriz.

Título: Competências socioemocionais: efeitos do contexto escolar da religiosidade e mediação sobre o desempenho acadêmico.

Tese apresentada ao Programa de Pós-Graduação em Administração de Organizações da Faculdade de Economia, Administração e Contabilidade de Ribeirão Preto da Universidade de São Paulo, para obtenção do título de Doutora em Ciências. Versão Corrigida. A original encontra-se disponível na FEA-RP/USP.

Aprovada em: 20/05/2016

Banca Examinadora

Prof. Dr. Márcio Mattos Borges de Oliveira

Instituição: FEARP - USP

Assinatura:

Prof. Dr. Daniel Domingues dos Santos

Instituição: FEARP - USP

Assinatura:

Prof. Dr. Luiz Guilherme Dacar da Silva Scorzafave

Instituição: FEARP - USP

Assinatura:

Prof. Dr. Ricardo Primi

Instituição: USF

Assinatura:

Prof. Dr. Eduardo Luiz Gonçalves Rios-Neto

Instituição: UFMG

Assinatura: 

Aos meus pais, Sérgio e Maria Lúcia, e avós, Aos meus irmãos, Cláudia, Pedro e Deca, Ao muito querido Pedro Meurer Moreira, E a todos os professores do Brasil, a quem admiro. 



\section{AGRADECIMENTOS}

A história desta tese daria um filme de aventura e comédia. Sua evolução foi como diz o poema "nas pás de cada Moinho enxergo uma ideia perfeita, com engenho transporta a dita a força que mói o trigo", inspiração unida a muito esforço. Foi longo o trajeto até chegar nessa etapa conclusiva. Inicialmente pedi licença dos Correios e iniciei o doutorado com o intuito de me dedicar à proposição de uma ferramenta inovadora para os negócios de logística. O mundo deu voltas e resolvi me dedicar integralmente à vida acadêmica (uma das paixões da minha vida, apesar da ECT também ser). Então resolvi mudar o tema para uma das questões que mais me atraíram ao longo da vida, a pobreza. Mais especificamente, queria estudar soluções para a redução da pobreza. Com isso, acabei me voltando para a educação e, aprofundando, descobri o mundo das habilidades socioemocionais. Como o tema, ainda assim, é abrangente, cheguei a focar o estudo em questões bem diversificadas, desde instrumentos de mensuração (por onde comecei), indo para educação single-sex, peer effects, autoprodutividade, school tracking, rotatividade docente e tamanho de turma até chegar à religiosidade na escola. Gostei de todos e faria uma tese para cada um, mas gostei muito do resultado final ao qual chegamos. Conheci muita gente ao longo desse processo e não posso deixar de agradecer a todos, ainda que não tenha chegado a desenvolver o estudo no tema onde alguns me ajudaram. Enfim, são tantas as pessoas que eu gostaria de citar abaixo que terei que fazer um esforço, não pequeno, para nomear somente algumas.

Agradeço ao Prof. Márcio Mattos Borges de Oliveira, pelos muitos ensinamentos, compreensão, paciência e por ter apostado em mim desde o início.

Ao Prof. Daniel Santos, coorientador desta tese, sem palavras para agradecer, por sua maestria, comprometimento e por seu exemplo de ideal de vida, em querer melhorar o Brasil e o mundo, independente dos esforços que isso exija. Também por ter criado o Lepes, do qual sou fã incondicional.

À equipe do Lepes (Laboratório de Estudos e Pesquisas em Economia Social), não tenho palavras para agradecer a disponibilidade e apoio de todos (desde set more off perm e matpwcorr até trocar o pneu do carro rs), esta tese é de cada um de vocês também: Prof. Luiz Scorzafave, Prof $f^{a}$ Elaine Pazello, Gabriela Fonseca, Karen Granzotto, Victoria Martinez, Jaqueline Natal, Natalia Marchi, Lucas Lima, Matheus Mascioli, Elder Generozo, Felipe Polo, Tulio Dorigan, Mariana Boreli, Daniel Prado, Henrique Velasco, Reneide Campelo, João Lavinas, Miriam Wawrzyniak, Leonardo Assahide, Fabrício Alves, Marcelo Domingues, Jessica Miranda, Bruna Oliani, Gabriel Bechelli, Rogiene Batista, Fernando Lollo, André Luna, Natan Viola, Lucas Kava, Denis Moreira, Leandro Anazawa e todos os outros. 
Ao João Carlos de Carvalho e Jaqueline Natal pelo apoio no início e fim deste estudo.

Às amigas que me ajudaram desde o começo, Luciana Cezarino e Cintia Nogueira.

Aos professores, pelos ensinamentos e auxílio, de modo especial à Adriana Backx, Sônia V. B. de Oliveira, Geciane Porto, Alberto Matias, Dante Martinelli, Paulo Miranda, José Aparecido, João Passador, Irene Miura, José Dutra, Evandro Saidel, Alexandre Salgado, Erasmo Gomes, Rogério Calia, Lara Liboni, Adriana Caldana e Perla Rebehy.

Aos profissionais especiais que ajudaram ao longo do doutorado: Ricardo Primi, Monalisa Muniz, Tati Filgueiras, Tibor Braun, Oliver John, Filip de Fruyt, Angelo Varandas, Kai Lügger, Miriam Romano H. Porto, Wolfgang Glänzel, Pamela King, Beatrice Allain, Claudia Costin, Walkiria Chaina, Maria Augusta de Almeida, Benedicta Apparecida de Araújo, Koji Miyamoto, Hiroko Ikesako, Tae-Jun Kim, Fred Mael, Pedro López, Eduardo Rios-Neto, Valter Afonso Vieira, Ana Claudia Oliveira, Marcelo Perin, Mário Juruena, Eliane Andrade, Elizabeth Vierheller, Luzmilla Flores, Roxana Velarde, Gina Pancorbo e Ivana Casali Robalinho.

Aos colegas da pós, pela ajuda e amizade, Naya Ringer, Julia Tittoto, Elisa Marin, Gabriela Assis, Jessâmine Salvini, Thais Guelfi, Lilian Oliveira, Manuela Moreno, Luana Zanetti, Jonny Rodrigues, Marcelo Nogueira, Adriana Sicuto, Priscila Fassini, entre outros.

À equipe da Fearp, especialmente à Erika Veronezi, Matheus Carlos da Costa, Thiago Sasso, Silvio Bezerra de Noronha, Henrique Shuhama e Vânia Prudêncio.

A todos da Empresa Brasileira de Correios e Telégrafos, que me apoiaram na decisão de fazer este doutorado e em todos os trâmites necessários. Se fosse citar todo mundo, não caberia nesta página. Essa empresa vai sempre morar no meu coração, vocês são demais!

Ao Chris Martin, Guy Berryman, Jonny Buckland, Will Champion, Paula Toller, George Israel e Bruno Fortunato, pelas inspirações nas músicas.

À Capes, pela bolsa recebida durante esse período.

A todas as minhas amigas queridas, para falar de uma eu teria que falar de todas, vocês entendem não é?! Então coloco no genérico, além de quem já citei anteriormente.

E, at last but not least, à minha Família linda!! Não dá para colocar todo mundo, então cito Sérgio Willemsens, Maria Lucia Moreira Willemsens, Cláudia Willemsens, Pedro Willemsens, Andréa Willemsens, Antonio Paulo de A. Sodré, Mauricio Lamosa, João Francisco W. Kastrup, Joaquim Frederico W. Kastrup, Maria W. de A. Sodré, Tom Willemsens Lamosa, Elizabeth Richard, Maria Núbia dos Santos e Danielle Stern. A Vovó Wanda acompanhou de perto esta tese, mas não chegou a ver o resultado final, a ela agradeço especialmente por toda a vibração e alegria a cada passo. Entre família e amizades, a gente chega longe nessa vida! 
"No que diz respeito ao empenho, ao compromisso, ao esforço, à dedicação, não existe meio termo. Ou você faz bem feito ou não faz". "Se a gente quiser modificar alguma coisa, é pelas crianças que devemos começar. Devemos respeitar e educar nossas crianças para que o futuro das nações e do planeta seja digno". 



\section{RESUMO}

WILLEMSENS, B. Competências socioemocionais: efeitos do contexto escolar da religiosidade e mediação sobre o desempenho acadêmico. 2016. 120p. Tese (Doutorado) Faculdade de Economia, Administração e Contabilidade de Ribeirão Preto, 2016.

No mundo atual, é crescente a convicção de que a educação precisa ser reformulada de forma a priorizar, não somente o aprendizado acadêmico, mas também o desenvolvimento das competências socioemocionais. Tais competências são tão necessárias quanto as cognitivas para a promoção do bem estar individual e o progresso social: podem ampliar a capacidade de relacionamento interpessoal, a inteligência emocional e promover o atingimento de objetivos, entre outros, constituindo uma ferramenta importante a ser considerada pelos governos com vistas à diminuição das lacunas entre resultados educacionais, econômicos e sociais. $\mathrm{O}$ presente trabalho busca contribuir para a evolução do conhecimento científico sobre as competências não cognitivas e das práticas educacionais que contribuem para sua formação por meio da análise do contexto escolar da religiosidade, cuja influência positiva sobre o desenvolvimento juvenil tem atraído a atenção crescente de pesquisadores (YONKER et al., 2012). O estudo é dividido em duas partes: a primeira investiga as associações entre a religiosidade na escola e o desenvolvimento socioemocional, sobretudo de acordo com a vulnerabilidade de alunos em termos socioeconômicos e familiares, e a segunda verifica se os atributos socioemocionais exercem papel de mediação nos efeitos deste contexto escolar sobre o desempenho acadêmico. Foram utilizados dados de uma pesquisa com 23.133 alunos da rede pública do Rio de Janeiro, da Prova Brasil, Censo Escolar e SAERJINHO. Mediante estimações de mínimos quadrados ordinários, foram encontrados efeitos positivos da religiosidade, sobretudo sobre a conscienciosidade, lócus de controle interno, abertura a experiências, autoconfiança, autoestima e reflexão. Alunos com baixa escolaridade materna apresentam maiores benefícios. Por outro lado, análises realizadas por meio de equações estruturais apontam para uma mediação exercida por parte de algumas habilidades sobre as notas de português e matemática, concretamente a conscienciosidade, abertura a experiências e o lócus de controle.

Palavras-chave: competências socioemocionais, desempenho acadêmico, contexto escolar da religiosidade, análise de mediação. 



\begin{abstract}
WILLEMSENS, B. Socioemotional skills: effects of the school context of religiosity and mediation on academic performance. 2016. 120p. Tese (Doutorado) - Faculdade de Economia, Administração e Contabilidade de Ribeirão Preto, 2016.

There is a growing conviction today that education must be reformulated to prioritize not only academic learning but also the development of socioemotional skills. These competencies are as necessary as cognitive skills to promote individual well-being and social progress: they can intensify the ability to develop interpersonal relationships and emotional intelligence, and help people achieve their goals. These skills therefore represent a powerful tool to be considered by governments aiming to reduce the divide between educational, economic and social results. This study seeks to contribute to the advancement of scientific knowledge on non-cognitive skills and to educational practices that contribute to their development, based on an analysis of the school context of religiosity, whose positive influence on youth development has attracted increasing attention of researchers (YONKER et al., 2012). The study is divided into two parts: the first investigates the associations between religiosity in school and socioemotional development, above all from the standpoint of the vulnerability of students in socioeconomic and family terms, while the second part examines whether socioemotional attributes play a mediating role in the effects of this school context on academic performance. Data from a survey involving 23,133 students of the public school system in Rio de Janeiro were used, taken from the Prova Brasil, Censo Escolar and SAERJINHO. Based on ordinary least squares estimates, religiosity was found to have positive effects, particularly on the conscientiousness, internal locus of control, openness to experience, self-confidence, self-esteem and reflection. Students with low maternal education presented greater benefits. On the other hand, simultaneous structural equations analyses point to mediation exercised by some skills on academic grades in Portuguese and Mathematics, namely conscientiousness, openness to experience, and locus of control.
\end{abstract}

Keywords: socioemotional skills, academic performance, school context of religiosity, mediation analysis. 



\section{LISTA DE TABELAS}

Tabela 1. Descrição das variáveis da base de dados

Tabela 2. Estatísticas descritivas da amostra de alunos.

Tabela 3. Comparativo de características de escolas com e sem o contexto escolar da religiosidade

Tabela 4. Especificações dos modelos

Tabela 5. Estimativa dos efeitos do contexto de religiosidade nas habilidades socioemocionais

Tabela 6. Estimativa dos efeitos do contexto de religiosidade nas habilidades socioemocionais de alunos conforme a escolaridade da mãe.

Tabela 7. Estimativa dos efeitos do contexto de religiosidade nas habilidades socioemocionais de meninos e meninas com mães de baixa escolaridade.

Tabela 8. Estimativa dos efeitos do contexto de religiosidade nas habilidades socioemocionais de alunos divididos de acordo com a frequência de leitura dos pais

Tabela 9. Estimativa dos efeitos do contexto de religiosidade nas habilidades socioemocionais de alunos divididos de acordo com a presença ou ausência de incentivo de pais ao estudo.

Tabela 10. Estimativa dos efeitos do contexto de religiosidade nas habilidades socioemocionais de alunos com baixa escolaridade materna, pais sem frequência de leitura e sem incentivo de pais e dos pertencentes ao restante da amostra.

Tabela 11. Correlação entre socioemocionais e desempenho acadêmico

Tabela 12. Análise de mediação das habilidades socioemocionais nos efeitos do contexto escolar da religiosidade sobre o desempenho acadêmico

Tabela 13. Estimativa dos efeitos do contexto de religiosidade nas habilidades socioemocionais - amostra total de alunos

Tabela 14. Estimativa dos efeitos do contexto de religiosidade nas habilidades socioemocionais - alunos com baixa escolaridade materna 
Tabela 15. Estimativa dos efeitos do contexto de religiosidade nas habilidades socioemocionais - alunos com alta escolaridade materna....

Tabela 16. Estimativa dos efeitos do contexto de religiosidade nas habilidades socioemocionais - alunos com pais sem frequência de leitura

Tabela 17. Estimativa dos efeitos do contexto de religiosidade nas habilidades socioemocionais - alunos com pais com frequência de leitura

Tabela 18. Estimativa dos efeitos do contexto de religiosidade nas habilidades socioemocionais - alunos sem incentivo de pais

Tabela 19. Estimativa dos efeitos do contexto de religiosidade nas habilidades socioemocionais - alunos com incentivo de pais

Tabela 20. Estimativa dos efeitos do contexto de religiosidade nas habilidades socioemocionais - alunos com baixa escolaridade materna: meninos

Tabela 21. Estimativa dos efeitos do contexto de religiosidade nas habilidades socioemocionais - alunos com baixa escolaridade materna: meninas

Tabela 22. Estimativa dos efeitos do contexto de religiosidade nas habilidades socioemocionais de alunos com dummy de 3 vulnerabilidades $=1$ (baixa escolaridade materna, pais sem frequência de leitura e sem incentivo de pais)

Tabela 23. Estimativa dos efeitos do contexto de religiosidade nas habilidades socioemocionais de alunos com dummy de 3 vulnerabilidades $=0$ (baixa escolaridade materna, pais sem frequência de leitura e sem incentivo de pais) 


\section{LISTA DE GRÁFICOS}

Gráfico 1. Distribuição de brasileiros em cada religião por região

Gráfico 2. Distribuição de brasileiros em cada religião por escolaridade

Gráficos 3. Médias de habilidades socioemocionais de alunos de escolas sem religiosidade. 60

Gráfico 4. Médias de habilidades socioemocionais de alunos de escolas com religiosidade .. 60

Gráfico 5. Diferenças entre as médias de habilidades socioemocionais dos alunos na ausência

Gráfico 6. Habilidades socioemocionais por sexo: médias e efeitos da religiosidade na escola

Gráfico 7. Efeitos da religiosidade na escola sobre as habilidades socioemocionais de alunos de subgrupos menos favorecidos

Gráfico 8. Efeitos da religiosidade na escola sobre as habilidades socioemocionais de alunos de subgrupos mais favorecidos

Gráfico 9. Comparativo dos efeitos da religiosidade na escola sobre a conscienciosidade, abertura a experiências e lócus de controle de grupos menos e mais favorecidos

Gráfico 10. Comparativo dos efeitos da religiosidade na escola sobre os alunos mais vulneráveis entre os vulneráveis e dos pertencentes ao restante da amostra

Gráfico 11. Comparativo de médias de habilidades socioemocionais por desempenho acadêmico

Gráfico 12. Médias de habilidades socioemocionais por desempenho acadêmico crescente .. 90 



\section{LISTA DE FIGURAS}

Figura 1. Impacto da religiosidade/espiritualidade sobre habilidades socioemocionais e bem estar.

Figura 2. Mecanismos dos efeitos da religiosidade sobre o desenvolvimento do adolescente

Figura 3. Mudanças acumuladas no nível médio de personalidade ao longo do ciclo de vida

Figura 4. Modelo de mediação simples de habilidades socioemocionais nos efeitos do contexto escolar sobre o desempenho acadêmico

Figura 5. Mediação de habilidades socioemocionais nos efeitos do contexto escolar da religiosidade sobre o desempenho acadêmico 



\section{LISTA DE QUADROS}

Quadro 1. Panorama de competências para o séc. 21 segundo iniciativas globais

Quadro 2. Dimensões de vulnerabilidade familiar: realidades captadas e relações com habilidades e comportamentos dos filhos

Quadro 3. Dados empíricos sobre efeitos de habilidades socioemocionais sobre o desempenho acadêmico, sobre atitudes relacionadas ao aprendizado e questões relacionadas à neurociência 



\section{SUMÁRIO}

1 INTRODUÇÃO ................................................................................................................... 27

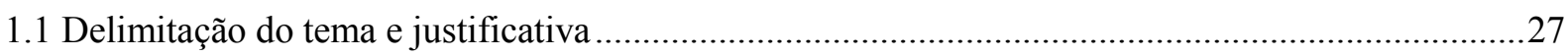

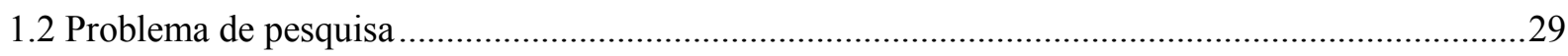

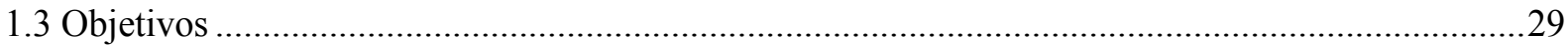

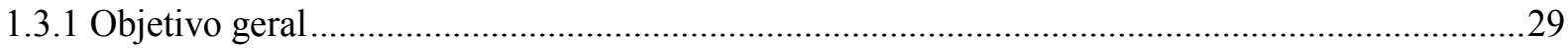

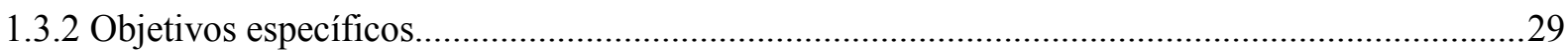

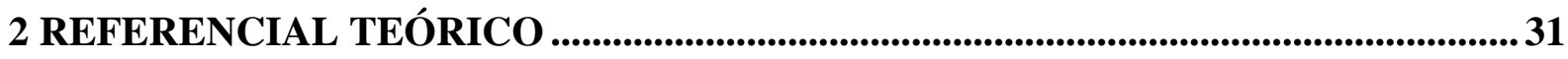

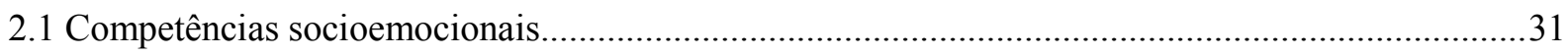

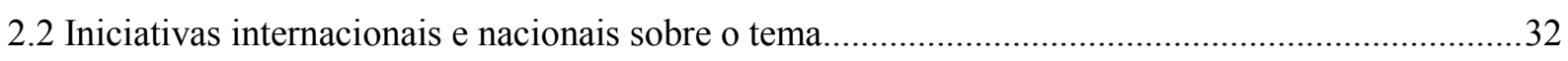

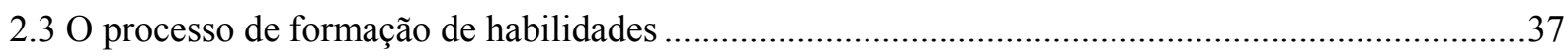

2.3.1 A influência dos contextos escolares sobre o desenvolvimento socioemocional...........................37

2.3.2 Os efeitos da religiosidade sobre o desenvolvimento socioemocional e seus mecanismos de

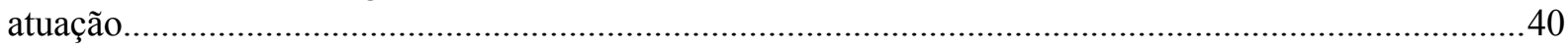

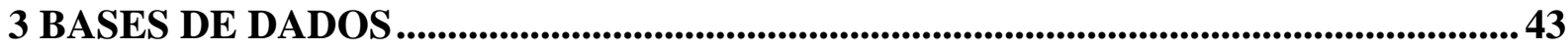

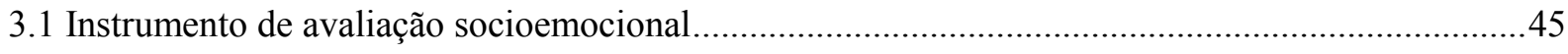

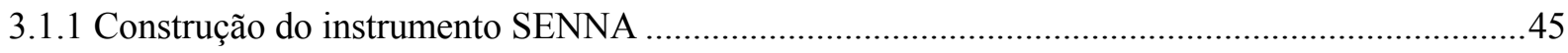

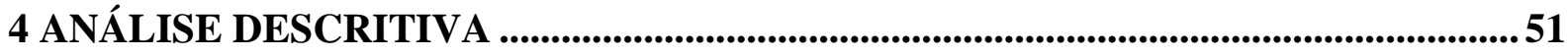

5 PRIMEIRO ESTUDO: EFEITOS DO CONTEXTO ESCOLAR DA RELIGIOSIDADE SOBRE AS HABILIDADES SOCIOEMOCIONAIS .....................55

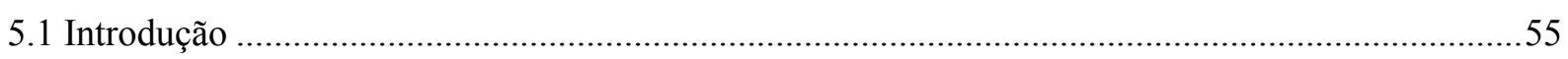

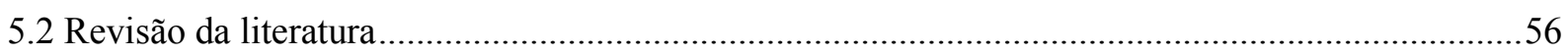

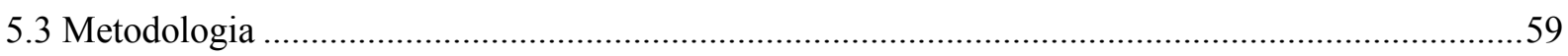

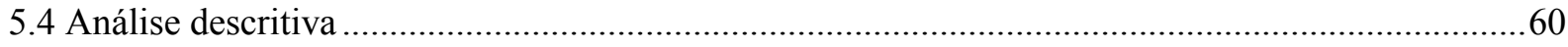

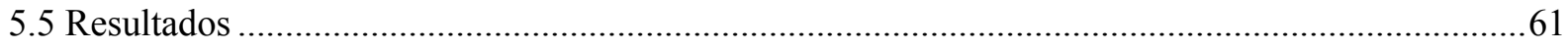

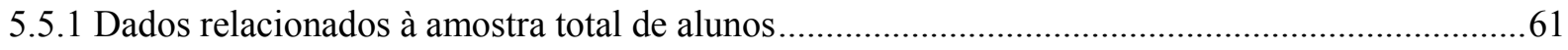

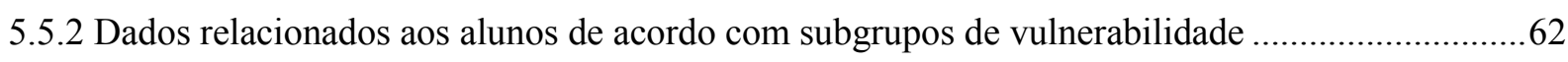

5.5.3 Comparativo dos efeitos significativos de alunos por subgrupos ...............................................66

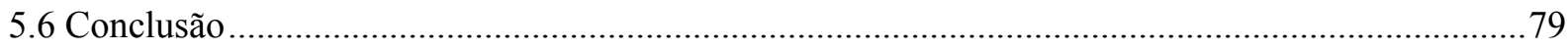


6 SEGUNDO ESTUDO: MEDIAÇÃO DAS HABILIDADES SOCIOEMOCIONAIS NOS EFEITOS DO CONTEXTO ESCOLAR DA RELIGIOSIDADE SOBRE O

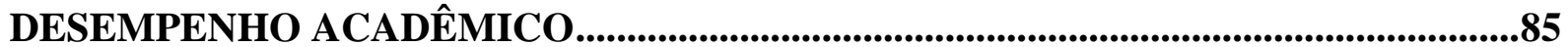

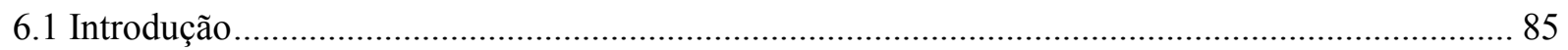

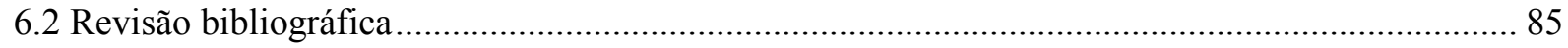

6.2.1 Diferenças entre os processos de formação de habilidades cognitivas e socioemocionais .......... 85

6.2.2 Os efeitos das habilidades socioemocionais sobre o desempenho acadêmico ............................. 86

6.2.3 Efeitos da religiosidade sobre o desempenho acadêmico ............................................................... 89

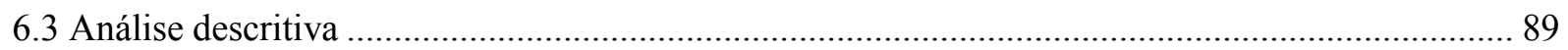

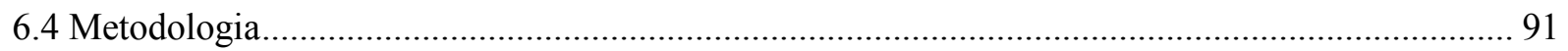

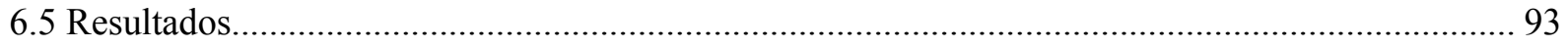

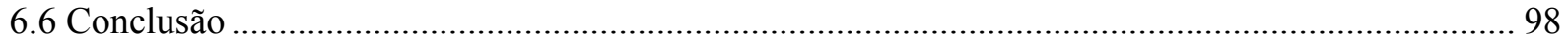

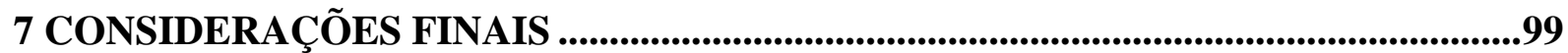

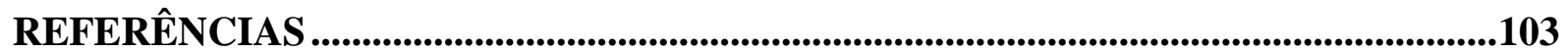

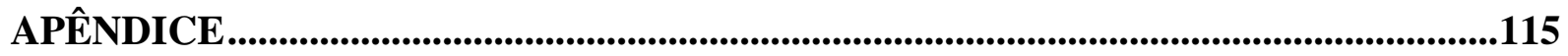

APÊNDICE A - Estimativas dos efeitos do contexto da religiosidade nas habilidades socioemocionais de alunos segundo o Modelo Longo .................................................................. 115 


\section{INTRODUÇÃO}

Esta tese investiga dois aspectos sobre as associações entre o desenvolvimento socioemocional e a religiosidade na escola: os efeitos deste contexto escolar sobre as habilidades não cognitivas, sobretudo para alunos menos favorecidos em termos familiares e econômicos, e o papel de mediação das competências socioemocionais nos efeitos deste contexto sobre o desempenho acadêmico.

Para isso, considerou-se oportuno dividir o trabalho da seguinte forma: primeiramente, expõem-se as principais questões referentes ao desenvolvimento socioemocional e ao contexto escolar da religiosidade, bem como outras questões em comum dos dois estudos, ou seja, as bases de dados e a análise descritiva das variáveis utilizadas e da religiosidade no Brasil. Após, procede-se à apresentação das questões específicas de cada estudo, ou seja, literatura, metodologia, análise descritiva dos dados, resultados e conclusão. Por fim, desenvolvem-se algumas considerações gerais sobre o trabalho realizado e seus resultados.

A seguir, são apresentados a delimitação do tema e a justificativa, o problema de pesquisa, bem como o objetivo geral e os específicos deste trabalho.

\subsection{Delimitação do tema e justificativa}

No mundo competitivo atual, a maior chance de obtenção e retenção de empregos recai sobre as pessoas mais bem preparadas em termos de conhecimentos e habilidades (STEELE-JOHNSON; NARAYAN; STEINKE, 2013). Entretanto, a partir de uma análise global, estima-se que 200 milhões de adolescentes, incluindo os que completaram o ensino médio, não possuem as habilidades necessárias para suas vidas e empregos (UNESCO, 2012).

Diante desse panorama, pode-se encontrar um amplo leque de estudos com foco nas competências cognitivas, abordando sua importância não somente no nível individual como também no social e econômico (MURNANE; WILLETT; LEVY, 1995; HANUSHEK; WOESSMANN, 2008; WELSH et al., 2010). Porém, se no passado exigia-se, sobretudo, uma elevada preparação acadêmica e tecnológica para o sucesso profissional, atualmente é crescente o reconhecimento da importância das competências sociais e emocionais para o êxito do indivíduo no âmbito pessoal, empresarial e social (HECKMAN; STIXRUD; URZUA, 2006; DI FABIO; KENNY, 2012). Desta forma, aumentam também as pesquisas a respeito do desenvolvimento dessas habilidades não cognitivas (HECKMAN; RUBINSTEIN, 2001; DURLAK et al., 2011). 
Como uma iniciativa de destaque nesse tema, pode-se mencionar o Fórum Internacional de Políticas Públicas "Educar para as competências do século 21”, realizado no Brasil em março de 2014. Entre as diversas exposições, Barbara Ischinger, Diretora de Educação da OCDE (Organização para a Cooperação e Desenvolvimento Econômico), ressaltou a importância da educação e das habilidades para o crescimento econômico-social sustentável, sinalizando que as pessoas precisam de uma combinação adequada de competências para se adaptarem às rápidas mudanças dos mercados e para atingirem os mais altos resultados sociais possíveis para si mesmas, famílias e comunidades (OCDE, 2014a). Como relata o sumário final (OCDE, 2014b), a apresentação de James Heckman e o discurso de abertura apontaram para a importância das competências socioemocionais em relação à obtenção de melhores resultados educacionais, sociais e econômicos, destacando que tais habilidades podem ampliar a capacidade dos indivíduos de trabalharem com outras pessoas, lidar com emoções e atingir objetivos. Dessa forma, ressaltou-se que competências socioemocionais são tão importantes quanto as cognitivas para promover o bem estar individual e o progresso social. Por outro lado, foi abordado o seu papel sobre a desigualdade social: a promoção das competências certas por meio da educação seria uma ferramenta importante que governos deveriam considerar para diminuir as lacunas na sociedade. Assim sendo, por meio destas e outras colocações, reforçou-se a necessidade de promover esforços educacionais em desenvolver tais competências.

Porém, Santos (2014) faz um diagnóstico preocupante sobre o cenário atual, descrito a seguir. Verifica-se uma relativa escassez de análises de impacto de políticas e programas que busquem promover o sucesso individual e coletivo por meio do desenvolvimento não cognitivo: por um lado, não há ainda suficiente interesse por parte dos psicólogos e, por outro, é recente o processo de valorização de aspectos socioemocionais do desenvolvimento humano por parte dos economistas (que normalmente realizam esse tipo de investigação), bem como sua tentativa de entender e dominar os instrumentos de medição elaborados predominantemente por psicólogos. A maioria dos estudos disponíveis abrange programas de pequena escala, que não permitem generalizar as conclusões e, portanto, contribuir de forma mais significativa no processo de formulação de políticas públicas. Assim sendo, o autor sugere a necessidade de investigar os mecanismos presentes no processo de desenvolvimento socioemocional, de forma a verificar como essas competências poderiam ser alavancadas e ter seu progresso acelerado. Por outro lado, ressalta a importância de avaliar a efetividade da escola em promovê-las, de modo a oferecer subsídios para o desenho de práticas pedagógicas mais justas e eficazes. 
O presente trabalho pretende contribuir para o aprimoramento de políticas públicas no que se refere ao sistema de educação, bem como favorecer a evolução da produção acadêmica na área de competências socioemocionais, por meio da investigação das associações entre a religiosidade na escola e competências socioemocionais, analisando, além disso, se tais habilidades são mediadoras do efeito deste contexto escolar sobre o desempenho acadêmico. Pretende, com isso, também fornecer material para futuras pesquisas voltadas para a promoção do desenvolvimento socioemocional de crianças e adolescentes.

\subsection{Problema de pesquisa}

Define-se o problema desta pesquisa da seguinte forma: o contexto escolar da religiosidade influencia o desenvolvimento socioemocional? Além disso, há efeitos deste contexto sobre o desempenho acadêmico que são mediados por habilidades socioemocionais?

\subsection{Objetivos}

São descritos, a seguir, os objetivos deste trabalho.

\subsubsection{Objetivo geral}

Verificar as associações entre a religiosidade na escola e as competências socioemocionais e se tais habilidades são mediadoras do efeito deste contexto escolar sobre o desempenho acadêmico.

\subsubsection{Objetivos específicos}

a) Verificar se a religiosidade na escola exerce efeitos sobre habilidades não cognitivas;

b) Analisar se esses efeitos variam de acordo com vulnerabilidades familiares dos alunos;

c) Investigar o papel de mediação de atributos socioemocionais nos efeitos da religiosidade na escola sobre o desempenho acadêmico. 
30 | Introdução 


\section{REFERENCIAL TEÓRICO}

A seguir, é apresentado um referencial teórico que abrange: o tema das competências socioemocionais e seu processo de formação, estudos realizados a respeito da influência dos contextos escolares sobre o desenvolvimento socioemocional, efeitos da religiosidade sobre esse desenvolvimento, bem como seus mecanismos de atuação.

\subsection{Competências socioemocionais}

São amplas e variadas as abordagens referentes às competências não cognitivas (ou socioemocionais), ainda que não qualificadas dentro dessa denominação. Entre os estudos que investigam esse tema, destacam-se profissionais da psicologia, educação e economia da educação, porém há também trabalhos de pesquisadores da saúde, em especial da neurociência, bem como da sociologia, administração, entre outros.

Um dos campos de pesquisas refere-se à psicologia positiva, focada no desenvolvimento de qualidades que ajudam os indivíduos e comunidades não apenas a resistir e sobreviver, mas a ir mais além e prosperar, abrangendo questões como otimismo, coragem, habilidades interpessoais, perseverança, responsabilidade e altruísmo (SELIGMAN; CSIKSZENTMIHALYI, 2000). Desta forma, direcionando esforços em elevar as forças humanas mais do que em eliminar fraquezas, foram sendo desenvolvidos trabalhos, por exemplo, sobre forças de caráter, tais como persistência, amabilidade, inteligência social, autorregulação e gratidão, entre outras, agrupadas em seis virtudes principais: sabedoria e conhecimento (forças cognitivas que implicam na aquisição e uso do conhecimento), coragem (forças emocionais que envolvem o exercício da vontade para atingir objetivos em face da oposição, externa ou interna), humanidade (forças interpessoais que envolvem cuidar e estabelecer amizade com os outros), justiça (forças ligadas à civilidade, que estão na base da vida comunitária saudável), temperança (forças que protegem contra o excesso) e transcendência (forças que forjam conexões com algo maior e fornecem significado) (PETERSON; SELIGMAN, 2004).

Dentro do campo dos "Estudos Organizacionais Positivos" (Positive Organizational Scholarship), surgiram análises no campo organizacional, procurando promover o melhor desempenho pessoal e organizacional por meio do desenvolvimento de virtudes, estimulando forças humanas, resiliência e vitalidade, entre outros (CAMERON; CAZA, 2004). Cabe destacar, ainda, os trabalhos desenvolvidos no âmbito do "Comportamento Organizacional 
Positivo" (Positive organizational behavior), no qual se destaca a exploração do conceito "Capital Psicológico" (Psychological Capital, também conhecido por PsyCap), constituído pelos recursos psicológicos positivos de autoeficácia, esperança, otimismo e resiliência (LUTHANS et al., 2007).

Entre outros atributos não cognitivos consagrados pela literatura, poder-se-ia citar o conceito de Autoestima de Rosenberg (1965); o Lócus de Controle de Rotter (1966), que reflete o quanto o indivíduo acredita ter controle ou não sobre os eventos que acontecem em sua vida; e a Inteligência Emocional, conceito desenvolvido por Peter Salovey, John Mayer e David Caruso (SALOVEY; MAYER, 1990; MAYER; CARUSO; SALOVEY, 1999) (para um melhor entendimento do conceito, pode-se recorrer ao artigo de Primi, 2003).

Nesse contexto, uma grande ênfase foi dada ao campo dos traços de personalidade, especialmente à teoria do Big Five (JOHN; SRIVASTAVA, 1999) que os agrupou em cinco grandes domínios: Conscienciosidade (tendência a ser organizado, esforçado e responsável), Estabilidade Emocional (previsibilidade e consistência de reações emocionais, sem mudanças bruscas de humor), Amabilidade (tendência a agir de modo cooperativo e não egoisticamente), Extroversão (orientação de interesses e energia em direção ao mundo externo e pessoas e coisas, ao invés do mundo interno da experiência subjetiva) e Abertura a Experiências (tendência a ser aberto a novas experiências estéticas, culturais e intelectuais) (conforme definições do dicionário da APA - Associação Americana de Psicologia). Nessa área dos conceitos no campo da personalidade, pode-se ainda mencionar a escala de avaliações autorreferentes (Core Self-Evaluations), que inclui quatro dimensões: Autoeficácia, Lócus de Controle, Estabilidade Emocional (ou Neuroticismo) e Autoestima (JUDGE, LOCKE E DURHAM, 1997).

\subsection{Iniciativas internacionais e nacionais sobre o tema}

O debate sobre as competências socioemocionais apresenta diversas linhas de enfoque, sendo algumas de suas principais vertentes resumidas no quadro apresentado por Lee (2013): 


\begin{tabular}{|c|c|c|c|}
\hline $\begin{array}{l}\text { P21 (Partnership for the } \\
\text { 21st Century Skills) }\end{array}$ & $\begin{array}{l}\text { ATC21s (Assessment } \\
\text { \& Teaching 21st Cent. } \\
\text { Skills) }\end{array}$ & OCDE & $\begin{array}{c}\text { European } \\
\text { Reference } \\
\text { Framework }\end{array}$ \\
\hline $\begin{array}{l}\text { Aprendizado e } \\
\text { Inventividade: } \\
\text { 1) Criatividade e Inovação } \\
\text { 2) Pensamento Crítico e } \\
\text { Resolução de Problemas }\end{array}$ & $\begin{array}{l}\text { Formas de Pensar: } \\
\text { 1) Criatividade e Inovação } \\
\text { 2) Pensamento Crítico, } \\
\text { Resolução de Problemas e } \\
\text { Tomada de Decisão } \\
\text { 3) Aprender a Aprender e } \\
\text { Metacognição }\end{array}$ & & $\begin{array}{l}\text { 1) Aprender a } \\
\text { Aprender }\end{array}$ \\
\hline $\begin{array}{l}\text { 3) Comunicação e } \\
\text { Colaboração }\end{array}$ & $\begin{array}{l}\text { Formas de Trabalhar: } \\
\text { 4) Comunicação } \\
\text { 5) Colaboração (trabalhar } \\
\text { em equipe) }\end{array}$ & $\begin{array}{l}\text { Interagir com Grupos } \\
\text { Heterogêneos: } \\
\text { 1) Relacionar com os } \\
\text { Outros } \\
\text { 2) Trabalho Cooperativo } \\
\text { em Equipe } \\
\text { 3) Arbitrar e Resolver } \\
\text { Conflitos }\end{array}$ & $\begin{array}{l}\text { 2) Comunicação na } \\
\text { Língua Nativa } \\
\text { 3) Comunicação em } \\
\text { Língua Estrangeira }\end{array}$ \\
\hline $\begin{array}{l}\text { Informação, Mídia e } \\
\text { Conhecimento Tecnológico: } \\
\text { 4) Alfabetização } \\
\text { Informacional } \\
\text { 5) Alfabetização em Mídia } \\
\text { 6) Alfabetização } \\
\text { Tecnológica (ICT) }\end{array}$ & $\begin{array}{l}\text { Ferramentas para o } \\
\text { Trabalho: } \\
\text { 6) Alfabetização } \\
\text { Informacional } \\
\text { 7) Alfabetização } \\
\text { Tecnológica (ICT) }\end{array}$ & $\begin{array}{l}\text { Usar Ferramentas } \\
\text { Interativamente: } \\
\text { 4) Usar Textos e Símbolos } \\
\text { de Linguagem } \\
\text { Interativamente } \\
\text { 5) Usar Conhecimento e } \\
\text { Informação } \\
\text { Interativamente } \\
\text { 6) Usar Tecnologia } \\
\text { Interativamente }\end{array}$ & $\begin{array}{l}\text { 4) Competência } \\
\text { Matemática e } \\
\text { Competências } \\
\text { Básicas em Ciência e } \\
\text { Tecnologia } \\
\text { 5) Competência } \\
\text { Digital }\end{array}$ \\
\hline $\begin{array}{l}\text { Talentos para a Carreira e } \\
\text { Vida: } \\
\text { 7) Flexibilidade e } \\
\text { Adaptabilidade } \\
\text { 8) Iniciativa e Auto- } \\
\text { Determinação } \\
\text { 9) Habilidade Social e } \\
\text { Multicultural } \\
\text { 10) Produtividade e Prestar } \\
\text { Satisfação } \\
\text { 11) Liderança e } \\
\text { Responsabilidade }\end{array}$ & $\begin{array}{l}\text { Viver no Mundo: } \\
\text { 8) Cidadania (Local e } \\
\text { Global) } \\
\text { 9) Vida e Carreira } \\
\text { 10) Responsabilidade } \\
\text { Pessoal e Social } \\
\text { (Incluindo Consciência, } \\
\text { Sensibilidade e } \\
\text { Compreensão de Aspectos } \\
\text { Culturais) }\end{array}$ & $\begin{array}{l}\text { Agir de Forma Autônoma: } \\
\text { 7) Agir Considerando o } \\
\text { Contexto Mais Amplo } \\
\text { 8) Formar e Conduzir os } \\
\text { Planos de Vida e Projetos } \\
\text { Pessoais } \\
\text { 9) Defender e Afirmar } \\
\text { Direitos, Interesses, } \\
\text { Limites e Necessidades }\end{array}$ & $\begin{array}{l}\text { 6) Competências } \\
\text { Cívicas e Sociais } \\
\text { 7) Senso de } \\
\text { Iniciativa e } \\
\text { Empreendedorismo } \\
\text { 8) Consciência, } \\
\text { Sensibilidade e } \\
\text { Expressões Culturais }\end{array}$ \\
\hline
\end{tabular}

Quadro 1: Panorama de competências para o séc. 21 segundo iniciativas globais

Fonte: Lee (2013)

Segundo Greenberg et al. (2003), o termo "Aprendizado Socioemocional", originalmente "Social and Emotional Learning" (SEL) foi introduzido pelo Fetzer Group como uma estrutura conceitual voltada para solucionar as necessidades nesse campo por parte de crianças e adolescentes, bem como a fragmentação de esforços nesse sentido tipicamente encontrada nas escolas (ELIAS et al., 1997). Eles acreditavam que, ao contrário de muitos programas "categóricos" de prevenção que visavam problemas específicos, o SEL poderia enfrentar as causas subjacentes dos problemas comportamentais, apoiando, ao mesmo tempo, o desempenho acadêmico dos alunos. 
Em 1994, foi criado o CASEL (Collaborative for Academic, Social and Emotional Learning), na Universidade de Illinois em Chicago, com vistas a fornecer recursos e evidências para a promoção do SEL, concretamente com o objetivo de alavancar a ciência nesse campo e expandir essa prática. Desde então, esse instituto busca reunir e promover pesquisas, influenciando as políticas educacionais e de saúde mental (HROMEK E ROFFEY, 2009). As principais metas dos programas SEL consistem em promover o desenvolvimento de cinco conjuntos inter-relacionados de competências cognitivas, afetivas e comportamentais: autoconhecimento, autogestão, percepção social, gestão de relacionamento e tomada de decisão responsável (CASEL, 2005).

Já em 2002, foi fundada a P21 - Partnership for the 21st Century Skills, uma organização americana que busca exercer um papel catalisador na promoção das competências necessárias para o século 21, construindo parcerias colaborativas entre os líderes educacionais, empresariais, comunitários e governamentais, de forma que todos os alunos possam adquirir os conhecimentos e habilidades que precisam para prosperar no mundo atual.

No Reino Unido, por sua vez, as práticas relacionadas ao aprendizado socioemocional têm aumentado progressivamente, chegando ao ponto de se demandar para todas as escolas que sigam o programa SEAL (Social and Emotional Aspects of Learning) (DEPARTMENT FOR EDUCATION AND SKILLS, 2005). Por outro lado, na Austrália, também são encontradas iniciativas neste sentido, motivadas pela preocupação em reduzir o bullying escolar e aumentar a resiliência dos alunos, juntamente como a preocupação em promover a conscientização de valores nas escolas (Values for Australian Schools) (HROMEK E ROFFEY, 2009).

No Brasil, reconhecendo a importância do assunto, um expressivo movimento fundado em 2006, o Todos pela Educação (TPE) incluiu, entre as 5 Atitudes propostas para promover o aprendizado de crianças e adultos, a Atitude $\mathrm{n}^{\circ}$ 2: "Promover as habilidades importantes para a vida e para a escola". Tal decisão não ocorreu de forma isolada, tendo sido decorrente de uma ampla ação para ouvir opiniões de pais de alunos e educadores a respeito de que ações e comportamentos proporcionariam a almejada parceria entre família, escola e comunidade virar realidade e que impactariam positivamente no aprendizado dos alunos. A Atitude $\mathrm{n}^{\mathrm{o}} 2$ refere-se à necessidade de promover o desenvolvimento de habilidades que, se estimuladas desde cedo têm maior probabilidade de serem absorvidas e praticadas no dia a dia, como responsabilidade, persistência, concentração, disciplina, comunicação e trabalho em equipe. 
Em outras palavras, as chamadas "soft skills" ou "non-cognitive skills", ou ainda, competências socioemocionais.

Entre as ações envolvendo diferentes países, pode ser mencionado o "VII Encontro Internacional de Educação" promovido pela Fundação Telefônica para debater a educação na era digital, em rede e eventos presenciais em cidades ibero-americanas: Buenos Aires, Santiago, Medellín, Lima, Cidade do México, Rio de Janeiro, Quito, Caracas e Madri. O evento durou 18 meses, de 2012 a 2013, e ofereceu uma série de conclusões em diferentes aspectos educacionais, como a de que é necessária a educação emocional para se chegar aos 2 últimos pilares da educação conforme o Relatório Delors, "aprender a viver juntos e aprender a ser". Ressaltou-se que as crianças que aprendem habilidades sociais e emocionais têm maior êxito, não somente na escola, como em todas as áreas da vida e que as competências socioemocionais podem ser aprendidas da mesma forma que se aprende a ler, destacando-se que educar o coração é tão importante como educar a mente. Entre os caminhos indicados para educar emocionalmente, podem ser citados a instrução explícita de maneira sistemática na sala de aula; a necessidade de criar um ambiente propício para o aprendizado, seguro, respeitoso, solidário e bem gerenciado; bem como a consideração de que o trabalho conjunto da escola, pais e sociedade tem um papel significativo no desenvolvimento e na gestão correta das emoções e relações.

Por outro lado, uma iniciativa global de destaque ocorreu com o Fórum Internacional de Políticas Públicas "Educar para as competências do século 21", organizado pelo Ministério da Educação do Brasil, Instituto Ayrton Senna e OCDE (Organização par a Cooperação e Desenvolvimento Econômico), em 2014, e que contou com representantes de 14 países: Argentina, Brasil, Colômbia, Coreia, Equador, Estados Unidos, Letônia, México, Noruega, Paraguai, Peru, Portugal, Suécia e Uruguai. Os focos desse evento eram: a) Compreender quais competências socioemocionais são importantes; b) Compreender seus mecanismos de formação e desenvolver melhores práticas para promovê-las; c) Medir competências socioemocionais e melhorar políticas públicas e contextos de aprendizagem; d) Desenvolver estratégias para garantir uma abordagem plena e coerente para o desenvolvimento de competências. Entre os resultados apresentados, expôs-se que, para evoluir o processo de promoção de tais competências em crianças e adolescentes, seria necessário o seu agrupamento em um conjunto único para, então, mensurá-las e, dessa forma, conseguir impulsionar e acompanhar o seu desenvolvimento nas escolas de forma sistemática ${ }^{1}$.

\footnotetext{
${ }^{1}$ http://www.educacaosec21.org.br/foruminternacional2014/
} 
Com esse objetivo, foi apresentado, no Fórum, um amplo estudo realizado por Santos e Primi (2014), visando à construção de um instrumento que mensurasse tais habilidades (processo descrito mais adiante neste trabalho). Tal projeto foi alavancado pelo Instituto Ayrton Senna, em parceria com a OCDE (por meio do seu Centro para Pesquisa e Inovação Educacional) e a Secretaria Estadual de Educação do Rio de Janeiro. Após um longo processo, obteve-se um resultado final de seis competências socioemocionais: conscienciosidade, extroversão, abertura a novas experiências, amabilidade, estabilidade emocional e lócus de controle, mensuradas pelo instrumento denominado SENNA (Social and Emotional or Non-cognitive Nationwide Assessment). Em continuidade, foi desenvolvida uma nova versão, a partir da entrada de novos pesquisadores no projeto, Oliver John (Universidade da Califórnia) e Filip de Fruyt (Universidade de Ghent).

Entre as ações nacionais que poderiam ser mencionadas ao redor do assunto, cabe citar, ainda, a criação do eduLab21, em maio de 2015, por parte do Instituto Ayrton Senna. Trata-se de um laboratório de inovação dedicado à produção e disseminação de conhecimento científico para a melhoria da educação pública no Brasil. Visando fazer uma ponte entre o conhecimento das ciências e o mundo da educação, o laboratório busca produzir e mapear conhecimentos sobre quais são, como se desenvolvem e como se avaliam as competências importantes para se viver no século 21; sistematizar esses conhecimentos em uma base de referência útil e acessível a gestores, professores e demais atores comprometidos com a melhoria da educação; e disseminar esses conhecimentos via iniciativas de difusão e de cooperação técnica para desenho de políticas públicas.

Importante, também, destacar outras organizações nacionais que promovem estudos a respeito do tema da educação, como a Fundação Lemann, Fundação Maria Cecilia Souto Vidigal, Instituto Unibanco, Fundação Itaú Social, Instituto Aliança, Instituto Alfa e Beto, entre outros. 


\subsection{O processo de formação de habilidades}

O aprendizado e desenvolvimento dos alunos não ocorrem isoladamente, mas com a colaboração dos professores, em companhia de seus colegas e com o encorajamento de suas famílias. Nesse processo, conforme exposto por Cunha et al. (2006), o principal papel corresponde à família, que contribui com dotes genéticos, com os ambientes pré (ventre materno) e pós-natal que proporcionam aos filhos (dentro e fora de casa), além dos estímulos que pode ou não oferecer ao desenvolvimento dos mesmos. Algumas cumprem essa tarefa de forma precária, com consequências negativas para seus filhos. Porém, a partir de variados estudos de intervenção, sabe-se que é possível compensar parcialmente a exposição a ambientes adversos caso intervenções de alta qualidade sejam feitas suficientemente cedo na vida das crianças. As habilidades são multidimensionais e, apesar de sofrerem influências por parte de questões genéticas e ambientais, podem ser adquiridas. Sua formação segue um processo dinâmico, onde as competências adquiridas em um estágio do ciclo de vida afetam a produtividade de aprendizagem de outras na próxima fase. Esse processo de formação é mais eficaz quando começa em uma idade jovem e continua ao longo da vida adulta (HECKMAN, 2000).

Além da família, os autores destacam o papel do ambiente e a importância das ações pessoais no desenvolvimento das próprias habilidades. Por outro lado, outro fator decisivo para a formação não cognitiva de crianças e adolescentes consiste no contexto escolar onde estão inseridos, assunto abordado mais detidamente na sequência.

\subsubsection{A influência dos contextos escolares sobre o desenvolvimento socioemocional}

Diversos autores têm verificado efeitos significativos da escola sobre o desenvolvimento de crianças e adolescentes. Heckman et al. (2006), por exemplo, realizaram um estudo com dados longitudinais a partir de um modelo estrutural e investigaram a influência do ensino formal (a partir do fundamental) sobre o desenvolvimento cognitivo e não cognitivo. Em relação a aspectos de cognição, foram encontrados impactos significativos da escola em testes multidimensionais de inteligência, sobretudo a partir do fim do ensino médio. No que se refere a atributos socioemocionais, constatou-se que há impacto sobre a autoestima, de modo especial no ensino básico, e sobre o lócus de controle interno, onde o impacto cresce conforme o nível educacional.

Greenberg et al. (2003) realizaram um levantamento sobre os programas escolares de prevenção e intervenção para promover o aprendizado socioemocional e acadêmico, 
identificando três principais focos: o ambiente escolar, a pessoa e algumas incluindo múltiplas abordagens e componentes. Exemplos de esforços em relação ao ambiente enfatizavam: (a) desenvolvimento e planejamento organizacional da escola; (b) criação de comunidades de apoio para alunos e melhoria do clima da escola e da sala de aula; (c) fortalecimento das práticas de ensino dos professores e aumento do envolvimento da família; entre outros. Entre as iniciativas com foco na pessoa, foram verificados programas de promoção das competências não cognitivas em sala de aula e de prevenção de problemas de comportamento específicos, como o uso de drogas e violência.

Mais adiante, Durlak et al. (2011) efetuaram uma meta-análise sobre 213 programas escolares implementados para a promoção do aprendizado socioemocional, envolvendo 270.034 alunos do jardim de infância ao ensino médio. Constatou-se que, dentro de contextos escolares, o aprendizado socioemocional incorpora dois conjuntos coordenados de estratégias educacionais. O primeiro envolve instruções em relação ao processamento, integração e aplicação seletiva das competências não cognitivas. $O$ segundo busca estimular o desenvolvimento socioemocional dos alunos por meio da promoção de ambientes seguros e propícios para a aprendizagem, envolvendo colegas e familiares, uma melhor gestão da sala de aula e das práticas de ensino. Tais componentes oferecem recursos pessoais e ambientais para que os alunos se sintam valorizados e tenham maior motivação intrínseca para desenvolver competências socioemocionais que sirvam de fatores mediadores para um melhor desempenho acadêmico, entre outras questões. Além disso, os autores categorizaram os resultados gerados pelas intervenções em 6 grupos: 1) competências socioemocionais; 2) atitudes em relação a si mesmo e aos outros; 3) comportamento social positivo; 4) problemas de conduta; 5) estresse emocional e 6) desempenho acadêmico.

A categoria das "competências socioemocionais" incluiu diferentes tipos de habilidades cognitivas, afetivas e sociais (uma vez que muitos estudos foram baseados em programas SEL, que contemplam esses atributos), relacionadas a questões como saber identificar emoções, definição de metas, solução de problemas interpessoais e tomada de decisão. A avaliação dessas competências poderia ser baseada em relatórios de alunos, professores, pais ou avaliadores independentes. No entanto, todos os resultados nesta categoria refletem aquisição ou desempenho da habilidade avaliada em situações de teste ou tarefas estruturadas (por exemplo, entrevistas, dramatizações ou questionários). No que se refere às avaliações de professores sobre os comportamentos dos alunos em situações do cotidiano (por exemplo, a capacidade do aluno em controlar a raiva ou saber trabalhar com os outros), estas foram alocadas na categoria de comportamento social positivo, abaixo. 
O conjunto "atitudes em relação a si mesmo e aos outros" combina atitudes positivas não somente sobre si mesmo, como também à escola e temas sociais. São incluídos autopercepção (por exemplo, autoestima, autoconceito e autoeficácia), ligação com a escola (por exemplo, atitudes em relação a ela e aos professores) e crenças convencionais (ou seja, prósociais) sobre a violência, ajudar os outros, justiça social e uso de drogas. Todos os resultados nesta categoria foram baseados em auto-relatos de estudantes.

Sobre o efeito "comportamento social positivo", engloba questões como conviver com os outros no que diz respeito a comportamentos diários, em vez de desempenho em situações hipotéticas (o qual foi tratado na categoria das habilidades socioemocionais). Por exemplo, as avaliações de professores sobre habilidades sociais extraídas da escala Social Skills Rating Scale (ELLIOTT et al., 1988) foram colocadas nesta categoria.

O grupo "problemas de conduta" incluiu medidas de diferentes tipos de problemas comportamentais, tais como o comportamento disruptivo em classe, agressão, intimidação, suspensões escolares e atos delinquentes. Estas medidas, como o Child Behavior Checklist (ACHENBACH, 1991), poderiam vir de auto-relatos de estudantes, avaliações dos professores, pais, observadores independentes ou, no caso de suspensões escolares, a partir de registros da escola.

A categoria sobre "estresse emocional" englobou medidas de problemas de saúde mental, incluindo relatos de depressão, ansiedade, stress ou retraimento social, fornecidos pelos alunos, professores ou pais em instrumentos como a Children's Manifest Anxiety Scale (KITANO, 1960).

Por fim, as consequências referentes a "desempenho acadêmico" incluíram escores sobre testes padronizados de leitura e matemática, como o Stanford Achievement Test ou o Iowa Test of Basic Skills, assim como notas escolares. Somente os dados retirados de registros escolares foram incluídos, não englobando, por exemplo, avaliações dos professores sobre a competência acadêmica de alunos, nem medidas de QI como o Stanford Binet.

Por outro lado, como ressaltado por De Raad e Schouwenburg (1996), as habilidades não cognitivas podem exercer um papel de mediação no processo geral de aprendizado, pois interagem ou mediam sucessivas etapas da sequência de processamento de informações. Variáveis motivacionais podem mediar o impacto de fatores de estímulo; variáveis relacionadas à persistência podem mediar a manutenção da atenção seletiva, bem como variáveis ligadas a questões de inteligência e estilo cognitivo podem mediar a eficácia da fase do processamento de informações e assim por diante. 


\subsubsection{Os efeitos da religiosidade sobre o desenvolvimento socioemocional e seus mecanismos de atuação}

Conforme afirmado por King e Boyatzis (2015), os estudos sobre religiosidade no âmbito escolar podem ser divididos em dois grupos: aqueles que investigam os efeitos diretos de tais escolas no desenvolvimento acadêmico dos alunos e os efeitos indiretos da composição religiosa dos alunos no que se refere às suas vidas religiosas. Não são citadas pesquisas sobre as associações desses colégios com o desenvolvimento socioemocional dos alunos. De fato, no que se refere aos aspectos cognitivos, há tempos são ressaltados os efeitos positivos que escolas religiosas exercem sobre o rendimento escolar, desde os trabalhos pioneiros de Coleman et al. (1982) e Coleman e Hoffer (1987). Há, também, estudos sobre as consequências da religiosidade em questões variadas de comportamento, saúde e relacionamento interpessoal, entre outros (EBSTYNE KING, FURROW, 2004) e, inclusive, sobre mecanismos pelos quais ela proporciona melhores resultados educacionais (GLANVILLE et al., 2008). No Brasil, por sua vez, poderia ser citado o estudo realizado por Cunha, Rios-Neto e de Oliveira (2014) sobre a influência da religiosidade no desempenho acadêmico. Porém, não foram encontrados trabalhos que investigam a relação entre os colégios que possuem práticas religiosas e os atributos não cognitivos dos alunos. Assim, foi necessário recorrer à produção científica referente ao impacto que a religiosidade/espiritualidade (o fato de uma pessoa ser religiosa/espiritualizada) exerce sobre esse aspecto do desenvolvimento humano (conforme exposto a seguir). Neste caso, entende-se que, ao se proporcionar contato com a religiosidade no âmbito escolar, aumenta-se a probabilidade de um indivíduo optar por uma vida mais religiosa/espiritualizada e, assim, ter acesso aos seus efeitos positivos.

Pesquisas mostram benefícios da religiosidade em relação a habilidades socioemocionais, de modo especial de adolescentes. A meta-análise realizada por Yonker et al. (2012) examina associações entre espiritualidade/religiosidade e resultados psicológicos em adolescentes e jovens se aproximando da idade adulta. Foram analisados 75 estudos, desenvolvidos entre 1990 e 2010 e abrangendo 66.273 indivíduos. Os resultados que se referem às habilidades socioemocionais e às medidas de bem estar são resumidos na figura 1 . 


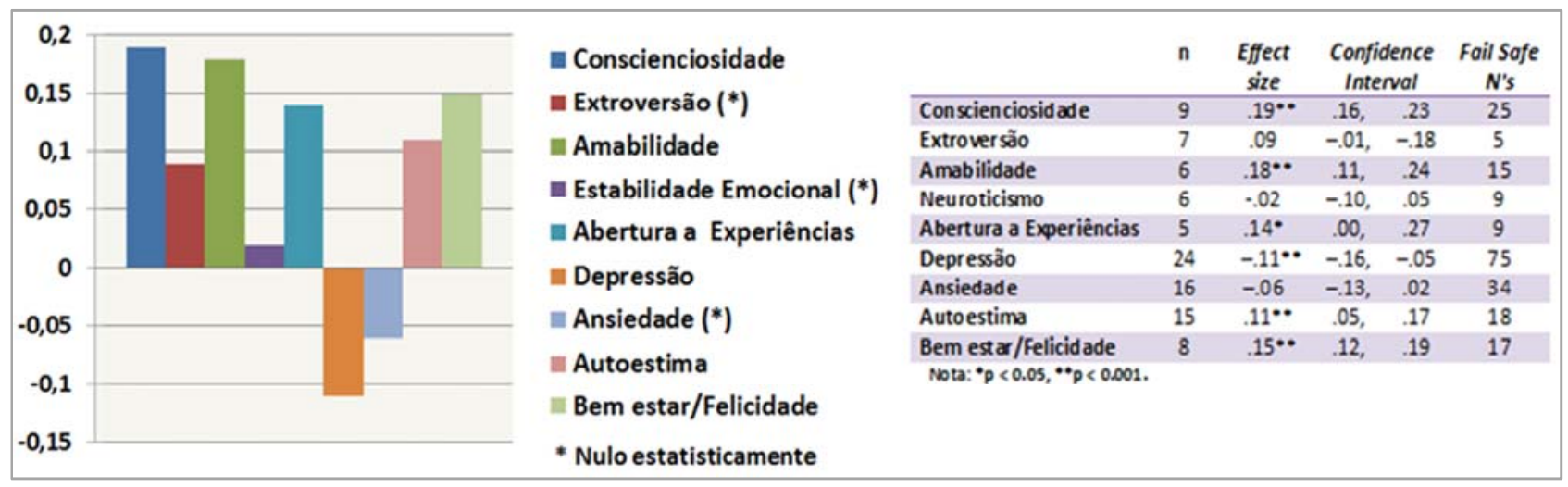

Figura 1. Impacto da religiosidade/espiritualidade sobre habilidades socioemocionais e bem estar

Fonte: Elaboração própria com base em Yonker et al. (2012)

Os estudos neste campo são abrangentes, englobando a investigação, ainda, de fatores como lócus de controle, autoconfiança, confiança nos outros, entre outros (MULLER, ELLISON, 2001; REGNERUS, 2003; BRAÑAS-GARZA, ESPÍN E NEUMAN, 2013), verificando-se efeitos maiores para os mais vulneráveis em termos de condições socioeconômicas, familiares e de saúde (NEAL, 1997; REGNERUS, ELDER, 2003, HUNMIER ET AL. 2002; WAITE, LEHRER, 2003), razão pela qual se investiga também as associações com a redução no envolvimento em criminalidade (EBSTYNE KING, FURROW, 2008; DONAHUE, BENSON, 1995).

No que tange aos estudos sobre mecanismos de influência da religiosidade sobre o desenvolvimento juvenil, expõe-se a seguir os trabalhos de Smith (2003) e King (2008).

Smith (2003) desenvolve um relato sistemático e integrado sobre os efeitos da religião em relação à juventude, propondo nove fatores distintos, porém conectados, que se reforçam mutuamente e que se agrupam em três dimensões: ordem moral, competências aprendidas e elos sociais e organizacionais. Antes de expor tais fatores, cabe sinalizar que o autor se refere às religiões existentes nos Estados Unidos não se restringindo, porém, às majoritárias (catolicismo e protestantismo), pois também cita aspectos de outras, como, por exemplo, do judaísmo.

No cluster de ordem moral, encontram-se: a) diretrizes morais, que, em termos gerais, dizem respeito a normas que incentivam a auto regulação e virtude pessoal, b) experiências espirituais, as quais, proporcionando questões como conforto espiritual e plenitude, solidificam as convicções, c) role models, ou seja, tem-se contato com exemplos positivos de vidas, não somente de líderes-referência, como também de pessoas com as quais os adolescentes convivem no dia a dia. No grupo de competências aprendidas, expõem-se: d) habilidades de grupo e de liderança, desenvolvidas pelo adolescente ao se deparar com a necessidade de, por exemplo, organizar iniciativas sociais, tomar parte de eventos onde se solicita sua participação ativa, interagir com pessoas diversas, etc. e) habilidades de coping, que são estimuladas por meio do oferecimento de crenças e práticas que ajudam a lidar com situações difíceis em termos sociais e psicológicos, a processar emoções e resolver conflitos interpessoais; f) capital cultural, que pode ser ampliado por 
oportunidades alternativas de aquisição de cultura geral (conhecimentos sobre história da religião, aprender a tocar instrumentos musicais, participar de coral, etc.). $\mathrm{Na}$ dimensão sobre elos sociais e organizacionais, são abordadas as estruturas de relações nas quais os adolescentes estão inseridos, dividindo em: g) capital social (por meio de interações individuais com pessoas de outras idades, o que enriquece o processo de desenvolvimento do jovem, entre outros); h) network closure: as religiões oferecem redes de relacionamento mais intensas, provendo os adolescentes de recursos adicionais e contatos com pessoas que incentivam boas práticas e desencorajam o inverso e assim por diante; i) elos extra-comunidade: oportunidades de conexão com pessoas de outras regiões, bem como experiências que vão além da própria comunidade.

Por sua vez, King aborda, em diferentes estudos (KING, 2003, KING, 2008 e KING, BOYATZIS, 2015), os mecanismos pelos quais a religião influencia o desenvolvimento juvenil, propondo três principais contextos: ideológico, social e transcendente. Sobre o ideológico, trata-se de que a espiritualidade favorece a concepção de um processo de formulação e encontro de significado para as próprias ações e decisões na vida, o que ajuda o adolescente a elaborar um próprio sentido de identidade, significado e propósito, questões que estão relacionadas à sua "construção pessoal" e socialização. O contexto social refere-se às oportunidades de distintas interações com pares e pessoas de outras gerações, bem como de participar de ambientes onde se proporcionam relacionamentos baseados na confiança e ajuda interpessoal. Por fim, o contexto transcendente baseia-se no conceito apresentado por The Fetzer Institute, onde se define a espiritualidade como algo relacionado ao transcendente, que aborda questões fundamentais a respeito do significado da vida, a partir da proposição de que há mais do que o que se pode ver ou entender totalmente. Aqui, a autora faz referência a religiões onde se enfatiza o valor único e inerente de cada pessoa e o quanto saber-se escolhido ou amado por um ser maior pode ter profundas implicações para a identidade pessoal (KING, 2003). A figura 2 apresenta um framework teórico sobre os mecanismos.
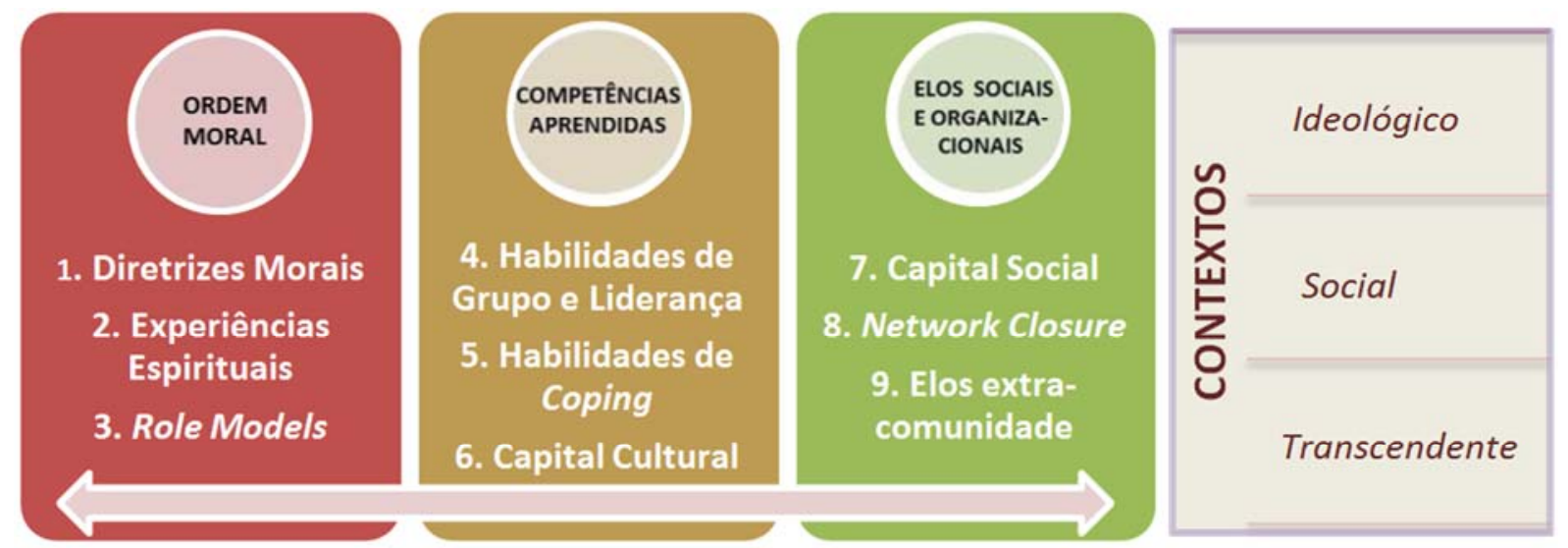

Figura 2. Mecanismos dos efeitos da religiosidade sobre o desenvolvimento do adolescente Fonte: Elaboração própria com base em Smith (2003) e King (2008) 


\section{BASES DE DADOS}

Para reunir os dados relevantes para este estudo, foi necessário compatibilizar, por meio do software estatístico STATA, a base de dados que contém os atributos não cognitivos e aspectos socioeconômicos com outros dois bancos que possuem informações sobre os contextos escolares nos quais os alunos estão inseridos. As bases são descritas abaixo.

Base de Dados das Habilidades Socioemocionais: base de microdados da pesquisa de campo realizada na rede estadual do Rio de Janeiro, em outubro de 2013, para validar o instrumento de medição socioemocional SENNA (Social and Emotional or Non-Cognitive Nationwide Assessment) (SANTOS; PRIMI, 2014). O projeto foi promovido pelo Instituto Ayrton Senna, em parceria com a OCDE - por meio do Centro para Pesquisa e Inovação Educacional - e a Secretaria Estadual de Educação do Rio de Janeiro (SEEDUC), tendo sido conduzido pelos pesquisadores Daniel Santos, da Universidade de São Paulo, e Ricardo Primi, da Universidade São Francisco. Além dos atributos socioemocionais, foram usados dados sobre as características individuais dos estudantes, seu ambiente familiar e comportamento dos pais. Este trabalho utiliza dados do $1^{\circ}$ e $3^{\circ}$ anos do ensino médio (23.133 alunos, 62,7\% do $1^{\circ}$ ano e $37,3 \%$ do $3^{\circ}$ ano).

Base de Dados sobre contextos escolares: Censo Escolar (proporção de professores com nível superior e proporção de professores de ensino religioso na escola), Prova Brasil (localização da escola e se há religiosidade na escola, em forma de práticas, objetos ou aula) e SAERJINHO (notas de português e matemática). 
Tabela 1. Descrição das variáveis da base de dados

\begin{tabular}{|c|c|c|}
\hline VARIÁVEL & & FONTE / DESCRIÇÃO \\
\hline $\begin{array}{l}\text { Habilidades } \\
\text { Socioemocionais }\end{array}$ & Tipo & Microdados da avaliação piloto no Rio de Janeiro \\
\hline $\begin{array}{l}\text { Conscienciosidade } \\
\text { Extroversão } \\
\text { Estabilidade Emocional } \\
\text { Amabilidade } \\
\text { Abertura a Experiências } \\
\text { Lócus de Controle }\end{array}$ & Contínua & $\begin{array}{l}\text { Análise fatorial (Teoria de Resposta ao Item) a partir de questionário } \\
\text { socioemocional (com } 92 \text { itens), conforme Santos e Primi (2014). } \\
\text { Os escores de cada habilidade socioemocional foram normalizados. }\end{array}$ \\
\hline Características individuais & Tipo & Microdados da avaliação piloto no Rio de Janeiro \\
\hline Sexo & Dummy & Dummy para menino \\
\hline Idade & Contínua & Idade \\
\hline Raça & Contínua & 4 categorias (branco, pardo, negro, asiático e indígena) \\
\hline Ambiente familiar & Tipo & Microdados da avaliação piloto no Rio de Janeiro \\
\hline Educação da mãe & Contínua & 5 níveis educacionais \\
\hline Alfabetização do pai & Dummy & Indica se pai sabe ler e escrever \\
\hline $\mathrm{N}^{o}$ de livros na residência & Contínua & 4 categorias (de nenhum a mais de 200 ) \\
\hline Mãe mora no domicílio & Dummy & Presença da mãe no domicílio \\
\hline Status socioeconômico & Contínua & Índice com 12 características de moradia e posse de bens duráveis \\
\hline Atitudes dos pais & Tipo & Microdados da avaliação piloto no Rio de Janeiro \\
\hline $\begin{array}{l}\text { Frequência de leitura dos pais } \\
\text { Incentivo dos pais }\end{array}$ & $\begin{array}{l}\text { Contínua } \\
\text { Dummy }\end{array}$ & $\begin{array}{l}4 \text { categorias (nunca a frequentemente) } \\
\text { Indica se os pais incentivam os filhos a estudar }\end{array}$ \\
\hline Ambiente escolar & & Censo Escolar e Prova Brasil \\
\hline Escolaridade docente & Contínua & Proporção de professores com nível superior (Censo Escolar) \\
\hline Localização da escola & Dummy & Dummy: 1 para área urbana e 0 para área rural (Prova Brasil) \\
\hline Biblioteca & Dummy & Indica se há biblioteca na escola (Prova Brasil) \\
\hline Desempenho acadêmico & Tipo & SAERJINHO \\
\hline Matemática & Contínua & Nota do aluno padronizada $(\mathrm{m}=0, \mathrm{v}=1)$ \\
\hline Português & Contínua & Nota do aluno padronizada $(\mathrm{m}=0, \mathrm{v}=1)$ \\
\hline Contexto escolar & Tipo & Censo Escolar e Prova Brasil \\
\hline Religiosidade na escola & Dummy & $\begin{array}{l}\text { Indica se há religiosidade na escola. Variável construída com a } \\
\text { combinação de dados do Censo Escolar (se há professores de ensino } \\
\text { religioso na escola) com os dados da Prova Brasil descritos abaixo: } \\
\text { Práticas: Diretor da escola respondeu: Sim. Na pergunta: "Nesta escola há } \\
\text { costume de se fazer oração ou cantar músicas religiosas (na entrada, antes } \\
\text { do lanche etc)". } \\
\text { Objetos: Diretor da escola respondeu: Sim Na pergunta: "Nesta escola há } \\
\text { objetos, imagens, frases ou símbolos de teor religioso". } \\
\text { Aula: Diretor da escola respondeu: Sim Na pergunta: "Nesta escola há } \\
\text { aula de ensino religioso". }\end{array}$ \\
\hline Facetas de socioemocionais & Tipo & Microdados da avaliação piloto no Rio de Janeiro \\
\hline $\begin{array}{l}\text { Autoconfiança } \\
\text { Autoestima } \\
\text { Curiosidade } \\
\text { Reflexão }\end{array}$ & Contínua & $\begin{array}{l}\text { Construtos formados a partir de correlação entre perguntas do } \\
\text { instrumento de mensuração socioemocional, verificando os agrupamentos } \\
\text { com os maiores coeficientes a um nível de significância de } 1 \% \text { e acima de } \\
\text { 0,3. Após, foi realizada uma normalização dos coeficientes das facetas. } \\
\text { As perguntas que compõem cada faceta são expostas abaixo: } \\
\text { Autoconfiança: "Acredito que posso mudar o que acontecerá comigo } \\
\text { amanhã pelo que faço hoje". } \\
\text { Autoestima: "Sinto que é inútil me esforçar na escola porque a maioria } \\
\text { dos alunos é mais inteligente do que eu". } \\
\text { "Costumo acreditar que sou um fracasso". } \\
\text { "Sinto que muitas vezes não vale a pena me esforçar porque, de qualquer } \\
\text { modo, as coisas nunca dão certo mesmo". } \\
\text { Curiosidade: "Vários assuntos despertam minha atenção". } \\
\text { "Gosto de conhecer algo novo". } \\
\text { Reflexão: "Gosto de refletir e brincar com minhas ideias". } \\
\text { "Gosto de pensar profundamente sobre as coisas". }\end{array}$ \\
\hline
\end{tabular}




\subsection{Instrumento de avaliação socioemocional}

Para avaliação das competências socioemocionais foi utilizado o instrumento SENNA (Social and Emotional or Non-cognitive Nationwide Assessment) elaborado e validado por Santos e Primi (2014). Como instrumento de mensuração, o SENNA possui atributos necessários e fundamentais para o estudo sobre as competências socioemocionais. São eles: ser simples e economicamente viável, podendo ser usado em ampla escala no sistema de educação; suficientemente preciso e interpretável, permitindo documentar o desenvolvimento socioemocional ao longo do ciclo de vida e como intervenções afetam essa trajetória e, principalmente, ser composto por itens internacionalmente reconhecidos, podendo ser facilmente adaptado para outra cultura.

\subsubsection{Construção do instrumento SENNA}

Para a construção de um novo instrumento com propriedades ótimas, primeiramente os autores identificaram e analisaram um amplo conjunto de instrumentos psicológicos na literatura internacional. Um requerimento importante para a seleção de cada instrumento foi a existência de evidência estatística que associasse o construto com alguma medida de bem estar. Desta seleção, 72 instrumentos foram avaliados em quatro dimensões consideradas importantes para seu uso. Foram elas: poder preditivo, factibilidade, maleabilidade e capacidade transformadora da escola e propriedades psicométricas. Após esta etapa, os instrumentos pré-selecionados foram agrupados em seis categorias, de acordo com os construtos que buscavam medir. Em quatro destas categorias foram encontrados instrumentos com características parecidas com aquelas que se buscavam. As categorias com os respectivos resultados desta análise foram:

Inventários de personalidade: questionários abrangentes com itens que, em princípio, deveriam cobrir todo o espectro de traços de personalidade. Nesta categoria, o instrumento Big Five Inventory (BFI) foi classificado como apropriado para a iniciativa.

Habilidades Sociais: questionários com mensuração de construtos relacionados a talentos interpessoais ou intrapessoais que tivessem consequências diretas sobre a capacidade de sociabilização. O instrumento Social Skills Improvement System (SSIS) foi eleito como o mais adequado aos propósitos da iniciativa. 
Características externalizantes, internalizantes e de temperamento: o instrumento Strengths \& Difficulties Questionnaire (SDQ) demonstrou ter propriedades desejáveis, predizendo, dentre outros, o desempenho individual em testes cognitivos.

Motivação e crenças: nesta categoria, estão escalas que buscam medir o lócus de controle, autoconceito, autoeficácia e autoestima. Para esta categoria, foram escolhidos os instrumentos de Lócus de Controle de Rotter e a escala de autoestima de Rosemberg.

Interesses profissionais e Miscelânea: nestas duas categorias, nenhum instrumento foi considerado satisfatório.

Os autores destacam uma limitação desta estratégia de seleção de instrumentos com base na revisão de literatura científica. Segundo eles, diversos instrumentos psicológicos competem em desigualdade de condições nos critérios que envolvem publicação de resultados em revistas científicas. Dois fatores podem afetar a seleção de instrumentos. Primeiro, os instrumentos mais antigos possuem uma maior probabilidade de terem sido utilizados em um maior número de estudos possuindo, portanto, maiores chances de estarem empiricamente associados com medidas de bem-estar e, em segundo lugar, instrumentos que foram incluídos em bases de dados públicas foram estudados com uma maior frequência tendo, também, maiores possibilidades de estarem correlacionados com medidas de bem-estar e maleabilidade em idades escolares.

Considerando a possibilidade de que instrumentos importantes pudessem ter ficado fora da seleção, consultaram-se especialistas com liderança internacional na produção acadêmica na área de Psicologia da Personalidade. Como resultado, para a categoria autopercepção, houve substituição do Lócus de Controle de Rotter pelo Lócus de Controle de Nowicki-Strickland, além da adição da escala de autoeficácia Self-Efficacy Questionnaire for Children (SEQ-C) e da escala de auto valoração Core Self Evaluations (CORE). Houve a inclusão da Grit Scale, que mede a capacidade individual de se propor um objetivo e perseverar até atingi-lo e a inclusão do Hierarquical Personality Inventory for Children (HiPIC). 
Após a consulta aos especialistas, a lista ficou composta por um conjunto de dez instrumentos candidatos à ferramenta final de mensuração das características socioemocionais:

- Core Self Evaluations

- Grit Scale

- Hierarquical Personality Inventory for Children (HiPIC)

- Nowicki-Strickland Locus of Control Scale

- Rosenberg Self-Esteem Scale

- Social Skills Improvement System (SSIS)

- Big Five for Children (BFC)

- Big Five Inventory (BFI)

- Self-Efficacy Questionnaire for Children

- Strengths and Difficulties Questionnaire (SDQ)

Depois da seleção dos instrumentos, efetivou-se uma nova etapa de estudos, visando:

1) Efetuar a tradução e a análise dos instrumentos para a identificação de aspectos sensíveis, como possíveis inadequações de linguagem e/ou conteúdo para o público-alvo;

2) Fazer a análise qualitativa da compreensão dos itens para detectar o grau de entendimento das questões por parte dos alunos, bem como a sua pertinência para a realidade sociocultural dos respondentes;

3) Verificar o tempo requerido para a realização dos testes por parte dos alunos;

4) Efetuar a análise psicométrica e a seleção de itens para o instrumento final.

O produto do primeiro objetivo foi uma versão traduzida e adaptada para uso no contexto escolar dos instrumentos listados. Após esses estudos, definiu-se uma bateria com oito testes a serem usados nos estudos subsequentes: Inventário dos Cinco Fatores (BFI), Inventário dos Cinco Fatores para Crianças (BFC), Questionário de Capacidades e Dificuldades (SDQ), Questionário de Autoeficácia para Crianças, Escala de Grit, Autoavaliações nucleares (Core), Escala de autoestima de Rosemberg, Escala de lócus de controle de Nowicki-Strickland. Ao fazer a análise qualitativa da compreensão dos itens, os autores concluíram que o teste para o $5^{\circ}$ ano deveria ter, no máximo, 60 itens e, para os alunos do $1^{\circ}$ e $3^{\circ}$ anos do ensino médio, poderia ter até 135 itens.

A nova lista, com oito instrumentos adaptados e traduzidos, possuía 21 subescalas com um total de 209 questões. Segundo alguns autores, os construtos podem ser entendidos como facetas dos cinco grandes domínios de personalidade. Então, Santos e Primi (2014) 
propuseram um entendimento das medidas abordadas nos instrumentos a partir das cinco variáveis latentes do Big Five: extroversão, conscienciosidade, abertura a novas experiências, amabilidade e estabilidade emocional. A partir do mapeamento das 21 escalas no modelo Big Five, tornou-se possível reduzir o seu número e, ainda, manter a representatividade dos construtos em um modelo unificador. Desta forma, por meio de uma análise fatorial, procurou-se estudar quantos agrupamentos seria possível resumir os itens e as escalas, além de verificar a possibilidade de usar o modelo Big Five. Para a análise fatorial, era necessário calcular a matriz de correlação "inter-itens", ou seja, a correlação de cada item com os todos os demais. Por ser na prática inviável, foi empregado um delineamento de Blocos Balanceados Incompletos. Ao final, a amostra ficou composta por 3.023 alunos de 16 escolas com desempenho médio em testes padronizados, das quais 86 classes participaram. O número de alunos respondentes por cadernos de prova variou de 93 a 252.

Depois do levantamento dos dados, foram realizadas uma análise fatorial exploratória das escalas e uma análise exploratória dos itens. Para a análise fatorial das escalas, verificouse que seis fatores poderiam ser considerados como diferentes de flutuação randômica. No entanto, por meio de análise das soluções de cinco e seis fatores, foi escolhida a solução mais parcimoniosa de cinco fatores. Em resumo, pôde-se observar que as dimensões poderiam ser interpretadas pelo modelo Big Five.

No primeiro encontro de especialistas em instrumentos para a avaliação de competências e habilidades do projeto Education and Social Progress - Longitudinal Study of Skill Dynamics, foi corroborada a proposta de que o modelo Big Five poderia ser usado como um modelo unificador para construção de instrumentos para avaliação dos construtos socioemocionais em larga escala.

No segundo momento, com intuito de compor um instrumento único e otimizado, a partir dos itens já existentes, e utilizando a análise fatorial exploratória dos itens, buscou-se identificar agrupamentos de itens que fossem consistentes com fatores descobertos na análise anterior, bem como selecionar itens que pudessem compor um novo instrumento com propriedades otimizadas. Nesta etapa, foram examinados 10 fatores em duas análises, uma com a amostra completa e outra apenas com alunos $5^{\circ}$ e $6^{\circ}$ anos. Os dez fatores encontrados foram: neuroticismo, conscienciosidade, abertura, amabilidade, extroversão, abertura a experiências, introversão, lócus de controle e problemas de conduta, autoestima com foco em sentimentos de tristeza e autoestima com foco em autoimagem negativa. A partir dessa análise, quatro pesquisadores revisaram independentemente a matriz de itens com suas cargas fatoriais item-fator e suas estatísticas descritivas e, cada um, a seleção de itens de acordo com 
critérios pré-definidos. Como resultado da seleção, chegou-se em uma versão consensual formada com 92 itens para os $1^{\circ}$ e $3^{\circ}$ anos do ensino médio e um subgrupo de 62 itens para o $5^{\circ}$ ano.

Uma vez desenvolvido um novo instrumento, realizou-se um estudo de medição em larga escala das habilidades socioemocionais na rede estadual do Rio de Janeiro com os seguintes objetivos: avaliar mais detidamente as propriedades psicométricas do instrumento; avaliar as habilidades socioemocionais dos alunos e descrever sua distribuição em razão de variáveis importantes relacionadas ao sistema educacional e investigar as associações das habilidades socioemocionais com o desempenho acadêmico em testes padronizados de desempenho.

Para a avaliação das propriedades psicométricas do novo instrumento, foram feitos três testes: uma análise fatorial confirmatória dos itens, verificando se era possível recuperar a estrutura de fatores definida no estudo anterior, uma análise fatorial com múltiplos grupos nas amostras, testando a invariância do modelo de medida, e empregou-se a Teoria de Resposta ao Item para calibrar os parâmetros dos itens e equalizar as pontuações dos alunos nas duas formas do teste. A conclusão, por meio dos resultados encontrados, foi que o instrumento possui elevado grau de consistência interna e é psicometricamente equivalente para os diferentes anos escolares amostrados. 


\section{ANÁLISE DESCRITIVA}

O Brasil caracteriza-se por ter um Estado laico no que diz respeito à sua Constituição, onde se prevê a liberdade religiosa, e, ao mesmo tempo, por ter uma população majoritariamente cristã (aproximadamente 87\%). O censo demográfico realizado em 2010, pelo IBGE, mostra uma distribuição por região (gráfico 1) onde se verifica uma predominância do catolicismo, seguido pelo protestantismo, tendo proporções mais abaixo de pessoas sem religião e uma parcela menor de outras religiões, onde se encontram o espiritismo, judaísmo, denominações afro-brasileiras e orientais, bem como pessoas que adotam o sincretismo religioso (múltiplas religiões), entre outros.

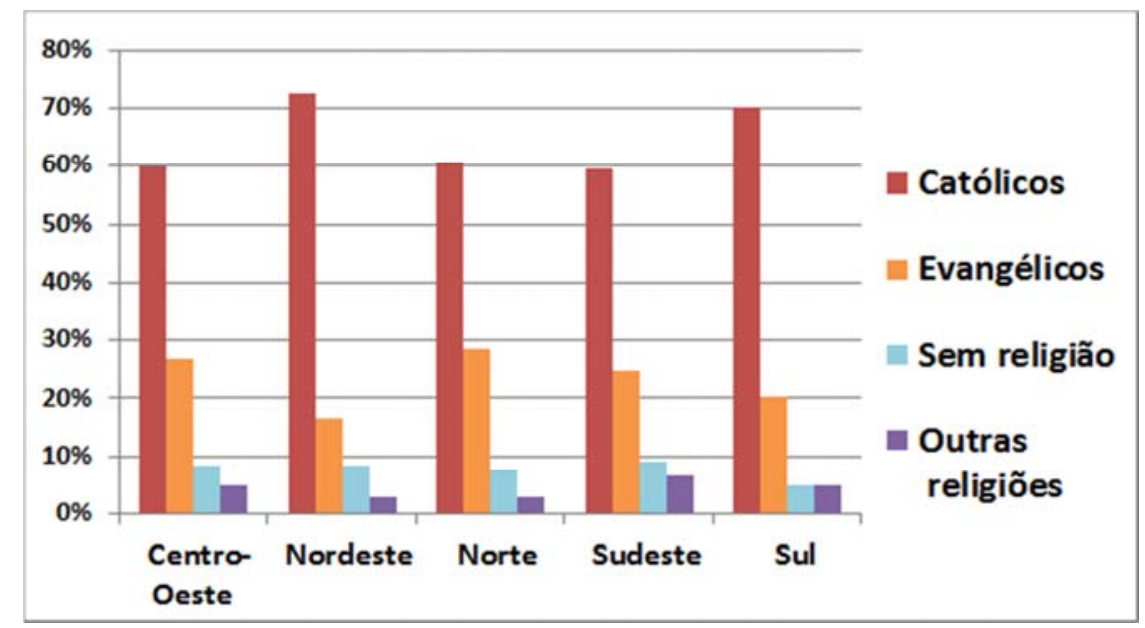

Gráfico 1. Distribuição de brasileiros em cada religião por região Fonte: Censo 2010

Quando se analisa a distribuição da religião em diferentes subgrupos, percebe-se que seguem um parâmetro similar, que acompanha o perfil geral do país, tendo algumas variações entre as religiões de menor frequência. No gráfico 2, apresenta-se a distribuição geral das denominações no país, comparando-a com os números de brasileiros por religião de acordo com seu grau de escolaridade.

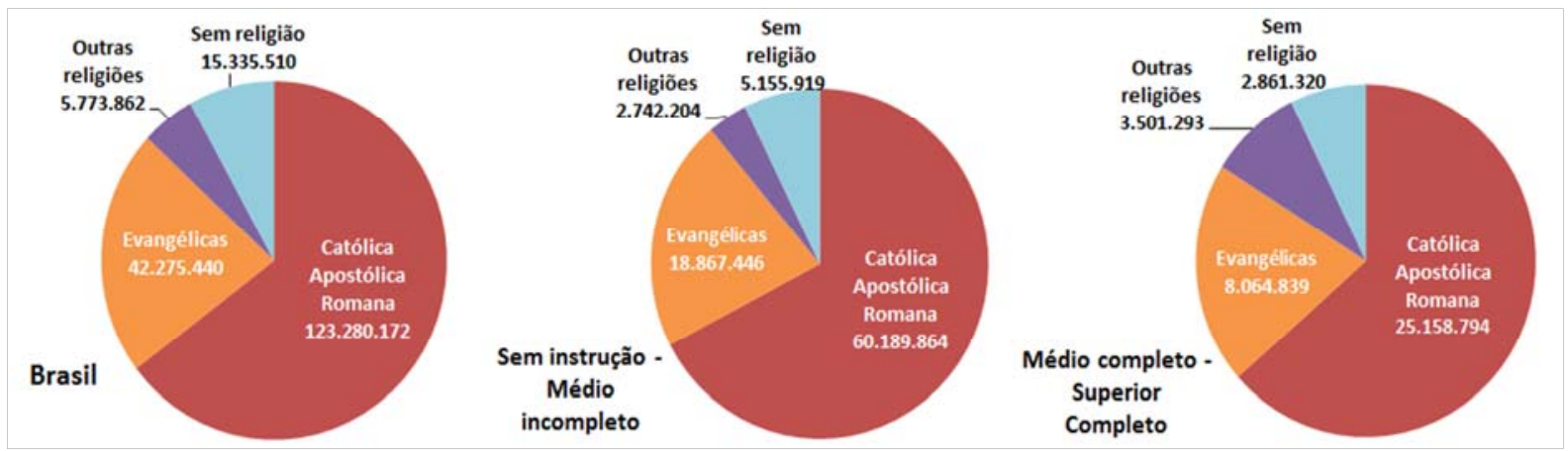

Gráfico 2. Distribuição de brasileiros em cada religião por escolaridade

Fonte: Censo 2010 
No que diz respeito à educação, a Constituição Federal brasileira prevê, em seu artigo 210, o oferecimento da disciplina de ensino religioso nas escolas públicas de ensino fundamental, dando, entretanto, ao aluno a opção de cursá-la ou não, pois a matrícula é facultativa.

Em relação a uma descrição do Brasil em termos de competências socioemocionais, ainda não existe uma pesquisa realizada em nível nacional que mostre essas características da população, apesar de haver estudos isolados que já começam a avaliar de forma mais quantitativa e sistemática essa dimensão para fins acadêmicos ou de elaboração de políticas públicas.

No que se refere às características da amostra de alunos pesquisados neste estudo, apresenta-se uma tabela com suas estatísticas descritivas.

Tabela 2. Estatísticas descritivas da amostra de alunos

\begin{tabular}{|c|c|c|c|c|c|}
\hline Variável & $\begin{array}{c}\mathrm{N}^{\mathbf{0}} \\
\text { Observações } \\
\end{array}$ & Média & $\begin{array}{l}\text { Desvio- } \\
\text { Padrão }\end{array}$ & Mínimo & Máximo \\
\hline \multicolumn{6}{|l|}{ Características individuais } \\
\hline Menino & 22.991 & $41 \%$ & 0,49 & 0 & 1 \\
\hline Idade & 22.697 & 17,07 & 1,31 & 15 & 23 \\
\hline Branco & 22.889 & $29 \%$ & 0,45 & 0 & 1 \\
\hline \multicolumn{6}{|l|}{ Ambiente familiar } \\
\hline Pai sabe ler e escrever & 22.397 & $91 \%$ & 0,28 & 0 & 1 \\
\hline $\begin{array}{l}\text { Mães com baixa escolaridade } \\
\text { (sem estudo até } 4^{\mathrm{a}} \text { série completo) }\end{array}$ & 22.662 & $28 \%$ & 0,45 & 0 & 1 \\
\hline $\begin{array}{l}\text { Mães com alta escolaridade } \\
\text { (ensino médio completo até } \\
\text { superior completo) }\end{array}$ & 22.662 & $41 \%$ & 0,49 & 0 & 1 \\
\hline Livros: nenhum a 1 prateleira & 22.390 & $72 \%$ & 0,45 & 0 & 1 \\
\hline Livros: mais de 1 estante & 22.390 & $6 \%$ & 0,24 & 0 & 1 \\
\hline Mãe mora no domicílio & 22.890 & $88 \%$ & 0,32 & 0 & 1 \\
\hline \multicolumn{6}{|l|}{ Atitudes dos pais } \\
\hline $\begin{array}{l}\text { Pais com frequência de leitura } \\
\text { (às vezes/sempre) }\end{array}$ & 22.385 & $79 \%$ & 0,41 & 0 & 1 \\
\hline Incentivo dos pais ao estudo & 22.283 & $82 \%$ & 0,39 & 0 & 1 \\
\hline \multicolumn{6}{|l|}{ Ambiente escolar } \\
\hline $\begin{array}{l}\text { Escolaridade docente (proporção } \\
\text { de professores com nível superior) }\end{array}$ & 23.113 & $97 \%$ & 0,04 & 0,75 & 1 \\
\hline Localização da escola (urbana) & 23.133 & $97 \%$ & 0,15 & 0 & 1 \\
\hline \multicolumn{6}{|l|}{ Contexto escolar } \\
\hline Religiosidade na escola & 13.795 & $44 \%$ & 0,49 & 0 & 1 \\
\hline
\end{tabular}

Fonte: Elaboração própria

A seguir, faz-se um comparativo entre as características de escolas sem e com o contexto da religiosidade, onde se pode constatar que não há diferenças significativas em questões relacionadas aos docentes e estrutura, entre outros. Nota-se, entretanto um percentual 
mais expressivo de bibliotecas em colégios com religiosidade do que nos que não possuem esse contexto escolar, motivo pelo qual julgou-se oportuno controlar essa variável no modelo de estimação que engloba características escolares, conforme mencionado na metodologia deste estudo.

Tabela 3. Comparativo de características de escolas com e sem o contexto escolar da religiosidade

\begin{tabular}{lcc}
\hline \multirow{2}{*}{ Características escolares (médias) } & \multicolumn{2}{c}{ ESCOLAS } \\
\cline { 2 - 3 } & $\begin{array}{c}\text { Sem } \\
\text { Religiosidade }\end{array}$ & $\begin{array}{c}\text { Com } \\
\text { Religiosidade }\end{array}$ \\
\hline Tamanho da Turma & 34,42 & 34,98 \\
Proporção de Docentes com nível & $95,63 \%$ & $97,15 \%$ \\
superior completo & $98,53 \%$ & $98,92 \%$ \\
Laboratório de Informática & 3,46 & 3,59 \\
IRD (Índice de Regularidade Docente) & $51,63 \%$ & $55,52 \%$ \\
Laboratório de Ciências & $81,28 \%$ & $93,18 \%$ \\
Biblioteca & $38,45 \%$ & $34,04 \%$ \\
Sala de Leitura & & \\
\hline
\end{tabular}

Fonte: Elaboração própria

A seguir, apresenta-se o primeiro estudo deste trabalho. 


\section{PRIMEIRO ESTUDO: EFEITOS DO CONTEXTO ESCOLAR DA RELIGIOSIDADE SOBRE AS HABILIDADES SOCIOEMOCIONAIS}

\subsection{Introdução}

Este trabalho investiga as relações entre a religiosidade na escola e o desenvolvimento socioemocional de alunos. Os efeitos benéficos da religiosidade sobre atributos não cognitivos têm atraído a atenção crescente de pesquisadores (YONKER et al., 2012), sendo que exercícios aprofundados mostram que os impactos são maiores entre os vulneráveis, o que sugere que o mecanismo pelo qual esta relação opera é por meio da compensação de oportunidades - incentivos - estímulos que essas famílias não têm condições de oferecer (processo de substitutibilidade).

Explicações para esse fenômeno são encontradas em estudos sobre os mecanismos da religiosidade (SMITH, 2003; KING, 2008), que esclarecem como os contextos ideológico, social e transcendente geram implicações para questões diversas, como significado, propósito de vida e relacionamento interpessoal, o que gera impactos na forma de viver e de se comportar em sociedade. Pessoas mais vulneráveis geralmente enfrentam carências de teor não somente material como em outras esferas, por exemplo, psicológica, social e afetiva. A religiosidade, por sua vez, oferece conforto espiritual, esperança e, sobretudo, a convicção de ser amado por um ser maior, o que pode ter profundas consequências para a identidade pessoal (KING, 2003). Em um segundo plano, há impactos sobre questões práticas, como acesso a role models (às vezes ausentes ou prejudiciais devido à condição familiar), que oferecem referências de comportamento e de objetivos, bem como de outros recursos, como capital social e cultural. Por esses e outros canais, tem-se verificado benefícios em populações menos favorecidas em termos socioeconômicos, especialmente, mas também com dificuldades em outros aspectos, como saúde (onde se encontram efeitos robustos, sobretudo sobre a depressão), problemas familiares, entre outros.

Foram analisados os efeitos deste contexto escolar para alunos de colégios públicos, além de se investigar especificamente se há vantagens no caso de algumas dimensões específicas de vulnerabilidade. Concretamente, o grau de escolaridade materna - indicador que capta um espectro mais amplo de condições desfavoráveis - e duas vertentes relacionadas ao ambiente familiar: incentivo dos pais ao estudo e hábito de leitura dos pais.

Optou-se por considerar a educação materna enquanto medida de vulnerabilidade do estudante por ser essa uma das variáveis usadas para se avaliar o status socioeconômico 
(BAKER, STEVENSON, 1986), sendo isso ainda mais adequado no caso do Brasil, país onde a escolaridade reflete mais expressivamente os rendimentos financeiros de uma pessoa (OCDE, 2015c). Outro motivo para essa escolha foi por se tratar de um indicador que capta, também, estilos de acompanhamento escolar dos filhos e ambiente familiar, além de outros fatores que influenciam o desenvolvimento cognitivo e socioemocional da criança e do adolescente (NEITZEL, DOPKINS STRIGHT, 2004). Por outro lado, julgou-se oportuno analisar, também, efeitos relacionados ao incentivo de pais para se captar aspectos não necessariamente refletidos pela escolaridade materna: a relação psicoafetiva entre pais e filhos e a motivação extrínseca ao estudo (POMERANTZ et al, 2007). A opção de incluir a dimensão familiar de frequência de leitura de pais foi motivada para captar questões relacionadas com capital cultural e, em consequência, motivação intrínseca para a aprendizagem (VILLIGER et al., 2012).

As características socioemocionais analisadas foram a conscienciosidade, estabilidade emocional, amabilidade, abertura a experiências, extroversão e lócus de controle interno. Após a realização de um levantamento na literatura sobre questões não cognitivas relacionadas a aspectos de vulnerabilidade, optou-se por incluir alguns construtos socioemocionais (facetas das variáveis citadas), mais especificamente: autoconfiança, autoestima e reflexão. A autoconfiança, por estar sendo indicada como necessária para a obtenção de melhores resultados acadêmicos, sobretudo dos mais desfavorecidos (OCDE, 2011a), a autoestima como fator que contribui para os rendimentos financeiros no longo prazo (DRAGO, 2008) e a reflexão como atributo necessário para a autonomia do aprendizado do aluno ao longo da vida, requisito para um bom desempenho profissional no futuro (ERTMER, NEWBY, 1996; FASTRÉ, 2013, PATERSON, CHAPMAN, 2013)

Este estudo é composto por sete seções: introdução, revisão bibliográfica, seguida pela metodologia, análise descritiva, resultados e conclusão.

\subsection{Revisão da literatura}

Esta breve revisão apresenta as dimensões de vulnerabilidade familiar abordadas neste trabalho.

É ampla a influência que a família exerce sobre o desenvolvimento do indivíduo, sendo preditora de grande parte de suas habilidades e resultados de longo prazo na vida (HECKMAN, 2008). Ela traz importantes insumos para a formação dos contextos ideológico, 
social e transcendente dos filhos, mediante ensinamentos, exemplos de vida e ambientes que lhes proporcionam dentro e fora de casa.

Entretanto, as famílias podem enfrentar vulnerabilidades em alguns sentidos, desde rendimentos financeiros até aspectos sociais, educacionais e culturais, entre outros, que acarretam lacunas nas contribuições necessárias para o crescimento adequado de seus filhos. As evidências são abrangentes. Autores expõem, por exemplo, que pais com menores níveis de educação contribuem de forma menos efetiva para a promoção do capital humano de seus filhos (FLOURI, 2006), dedicam menos tempo à sua formação (BIANCHI et al, 2006), proporcionam menos informações metacognitivas e dispõem de menos estratégias para suporte cognitivo, emocional e autônomo (NEITZEL, DOPKINS STRIGHT, 2004). Da mesma forma, estudos mostram que crianças que crescem na pobreza apresentam mais limitações de saúde, falta de suporte social e problemas de comportamento (CABRERA, 2011), bem como desempenhos inferiores em diversas esferas (MCLOYD, 1998). A falta de incentivo de pais aos filhos, por sua vez, implica em menos recursos motivacionais para crianças e adolescentes, deixando lacunas que vão além de desempenho escolar favorável, pois envolvem processos socioemocionais que abrangem questões como persistência, saber lidar com a ansiedade e percepções positivas em relação a si mesmo (POMERANTZ, 2007). Os autores sugerem, além disso, que a própria natureza afetiva desse envolvimento traz benefícios para o equilíbrio emocional dos filhos. As carências em âmbito cultural e intelectual, como falta de hábitos nesse sentido por parte dos pais (como o de leitura), também têm suas consequências negativas, especialmente associadas a aspectos do domínio da abertura a experiências, como curiosidade e intelecto, e na motivação intrínseca ao aprendizado, entre outros (VILLIGER et al., 2012).

Este estudo optou por investigar condições familiares que abarcam diferentes aspectos de vulnerabilidade, concretamente a escolaridade materna, o incentivo de pais ao estudo e a frequência de leitura de pais. Infelizmente, não foram encontradas meta-análises sobre os efeitos de cada uma dessas variáveis no desenvolvimento socioemocional (provavelmente porque ainda não existem muitos estudos sobre isso, como em outros campos, por exemplo, em relação ao desempenho acadêmico). Por isso, o quadro que se apresenta abaixo não pode ser considerado como algo semelhante a um framework teórico, é simplesmente um esforço em facilitar a visualização de algumas principais questões sobre cada dimensão, mais concretamente, um resumo sobre as realidades captadas por cada uma e suas relações com questões socioemocionais e comportamentais dos filhos, conforme verificado em alguns estudos mais abrangentes sobre o tema. 


\begin{tabular}{|c|c|c|}
\hline $\begin{array}{c}\text { Variáveis de } \\
\text { vulnerabilidade }\end{array}$ & Realidades que captam & $\begin{array}{l}\text { Relações com habilidades e } \\
\text { comportamentos dos filhos }\end{array}$ \\
\hline $\begin{array}{l}\text { Escolaridade da } \\
\text { mãe }\end{array}$ & $\begin{array}{l}\text { Status socioeconômico } \\
\text { Estilos de acompanhamento escolar dos } \\
\text { filhos } \\
\text { Ambiente familiar } \\
\text { Role models } \\
\text { Capital humano } \\
\text { Capital cultural } \\
\text { Suporte cognitivo } \\
\text { Vizinhança } \\
\text { Oportunidades aos filhos }\end{array}$ & $\begin{array}{l}\text { Abertura a experiências } \\
\text { Autoconfiança } \\
\text { Conscienciosidade } \\
\text { Delinquência juvenil } \\
\text { Estabilidade emocional } \\
\text { Habilidades cognitivas } \\
\text { Lócus de controle }\end{array}$ \\
\hline $\begin{array}{l}\text { Frequência de } \\
\text { leitura dos pais }\end{array}$ & $\begin{array}{l}\text { Pais com mais abertura a experiências } \\
\text { Ambiente familiar } \\
\text { Role models } \\
\text { Livros em casa } \\
\text { Capital cultural }\end{array}$ & $\begin{array}{l}\text { Abertura a experiências } \\
\text { Conscienciosidade } \\
\text { Curiosidade } \\
\text { Habilidades cognitivas } \\
\text { Motivação intrínseca para o } \\
\text { aprendizado }\end{array}$ \\
\hline Incentivo de pais & $\begin{array}{l}\text { Motivação extrínseca ao estudo } \\
\text { Estilos de acompanhamento escolar dos } \\
\text { filhos } \\
\text { Relação psicoafetiva entre pais e filhos } \\
\text { Ambiente familiar } \\
\text { Role models }\end{array}$ & $\begin{array}{l}\text { Autoconfiança } \\
\text { Autoestima } \\
\text { Conscienciosidade } \\
\text { Delinquência juvenil } \\
\text { Habilidades cognitivas } \\
\text { Motivação intrínseca para o estudo } \\
\text { Lócus de controle }\end{array}$ \\
\hline
\end{tabular}

Quadro 2. Dimensões de vulnerabilidade familiar: realidades captadas e relações com habilidades e comportamentos dos filhos

Fonte: Elaboração própria, com base em Baker e Stevenson (1986), Fox et al. (1995), Duncan e Brooks-Gunn (2000), Neitzel, Dopkins e Stright (2004), Kraaykamp, van Eijck (2005), Pomerantz et al. (2007) e Villiger et al. (2012).

A análise da tabela mostra que é amplo o panorama de deficiências que podem ser geradas por circunstâncias familiares desfavorecidas, sendo difícil encontrar recursos dentro das escolas que consigam abarcar todas as necessidades de alunos de diferentes procedências familiares, que podem apresentar carências em distintos sentidos. Por um lado, são documentados alguns programas e intervenções escolares de alta qualidade que obtiveram efeitos favoráveis na promoção cognitiva e socioemocional de alunos em casos que mostravam atrasos severos no desenvolvimento, como o Perry Preschool Project (CUNHA, HECKMAN, 2006). Porém, o alto custo de tais projetos compromete sua replicabilidade em termos de políticas educacionais mais abrangentes.

Um caminho para a solução do problema é apontado por dados empíricos que mostram que a religiosidade oferece maiores benefícios para públicos menos favorecidos, contribuindo na compensação de aspectos onde apresentam vulnerabilidades. Neste sentido, pela via da substitutibilidade, podem-se suprir carências em campos distintos de oportunidades, incentivos e estímulos que as famílias não conseguem ou não têm condições 
de oferecer aos seus filhos. As práticas religiosas no âmbito escolar, portanto, podem oferecer recursos para reparar lacunas no desenvolvimento de alunos de lares desfavorecidos.

\subsection{Metodologia}

Como só há dados socioemocionais de um período sobre a população a ser analisada, foi realizada uma estimação em cross section, regredindo as variáveis socioemocionais como dependentes e a do contexto escolar de religiosidade como explicativa. O método usado foi o de mínimos quadrados ordinários (MQO). Este método especifica uma equação linear em que os resultados socioemocionais (Y, chamado na equação de Socioemocionais) seriam explicados por estudar em colégio onde há religiosidade (Religiosidade), por um vetor de variáveis de controle (Controles) e por um escalar que sintetiza a influência de todos os determinantes não-observáveis de Y $(\varepsilon)$. A hipótese de seleção por observáveis é utilizada para garantir que não haja correlação entre esse termo não-observável e a variável de tratamento, o que aconteceria, por exemplo, no caso de termos omitido alguma variável que influencia a decisão das famílias de matricular os filhos em determinado colégio e pode afetar diretamente as variáveis de resultado.

As variáveis socioemocionais foram incluídas como dependentes uma de cada vez, tendo como variável explicativa o contexto de religiosidade, além de diversas variáveis de controle. A equação abaixo demonstra a estrutura de cada uma das equações estimadas, sendo $\beta$ nosso parâmetro de interesse (efeito do contexto escolar de religiosidade sobre as competências socioemocionais):

$$
\text { Socioemocional }=\varphi \text { Constante }+\beta \text { Religiosidade }+\theta \text { Controles }+\epsilon
$$

Visando obter estimativas mais robustas, foram testados quatro conjuntos diferentes de variáveis no vetor relacionado aos controles, conforme exposto na tabela abaixo.

\section{Tabela 4. Especificações dos modelos}

\begin{tabular}{ll}
\hline \multicolumn{1}{c}{ Modelos } & \multicolumn{1}{c}{ Variáveis de controle } \\
\hline Curto & Sexo, idade, raça. \\
Intermediário 1 & Modelo curto + educação mãe, alfabetização pai, se pais incentivam \\
& estudo, no livros na residência, frequência de leitura dos pais, se mãe \\
& mora no domicílio. \\
Intermediário 2 & Modelo intermediário 1 + status socioeconômico. \\
Longo & Modelo intermediário 2 + escolaridade do professor e localização da \\
& escola. \\
\hline
\end{tabular}




\subsection{Análise descritiva}

Em acréscimo aos dados já expostos na análise descritiva mais geral deste trabalho, considerou-se importante exibir, neste estudo, o perfil socioemocional (médias) de cada subgrupo por dimensão de vulnerabilidade. O gráfico 3 mostra as médias de habilidades não cognitivas de alunos de escolas sem religiosidade e o gráfico 4, por sua vez, esses índices relacionados aos estudantes que têm contato com esse contexto escolar.

Gráfico 3. Médias de habilidades socioemocionais de alunos de escolas sem religiosidade.

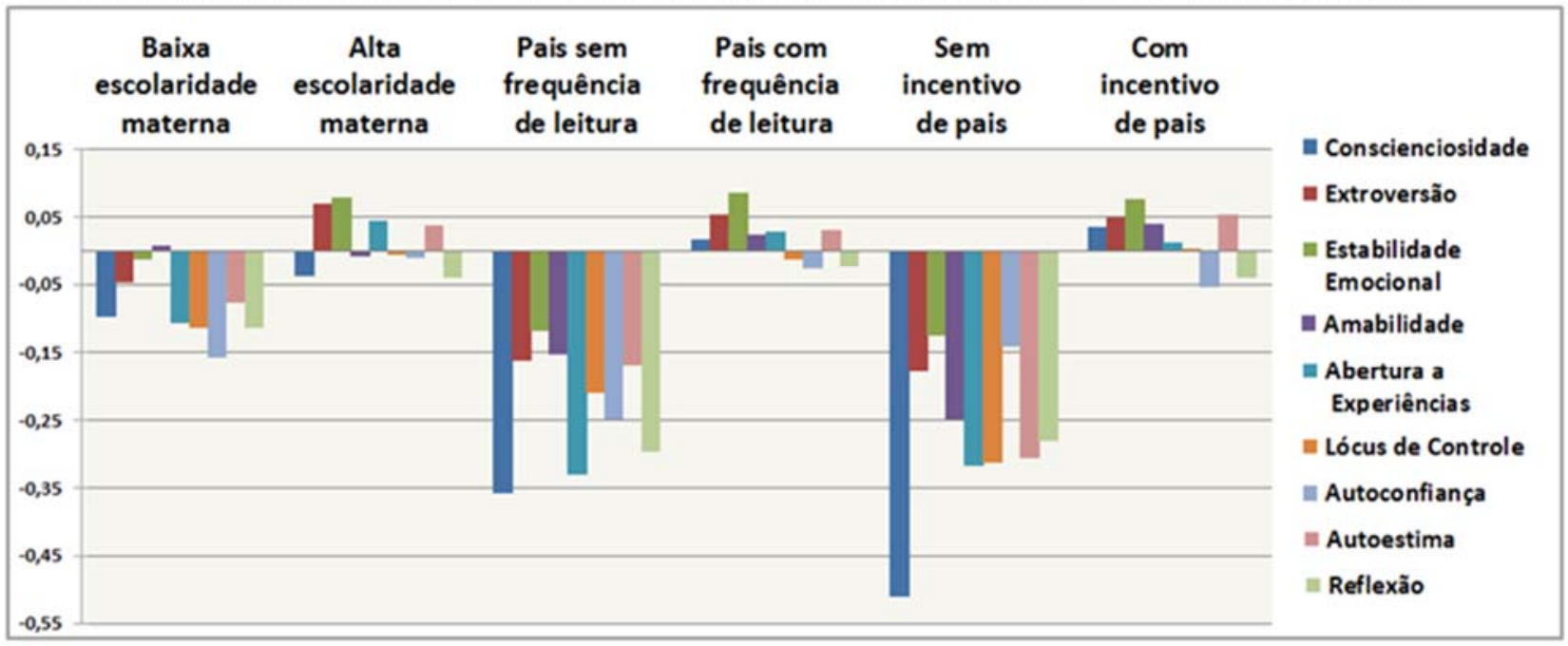

Gráfico 4. Médias de habilidades socioemocionais de alunos de escolas com religiosidade.

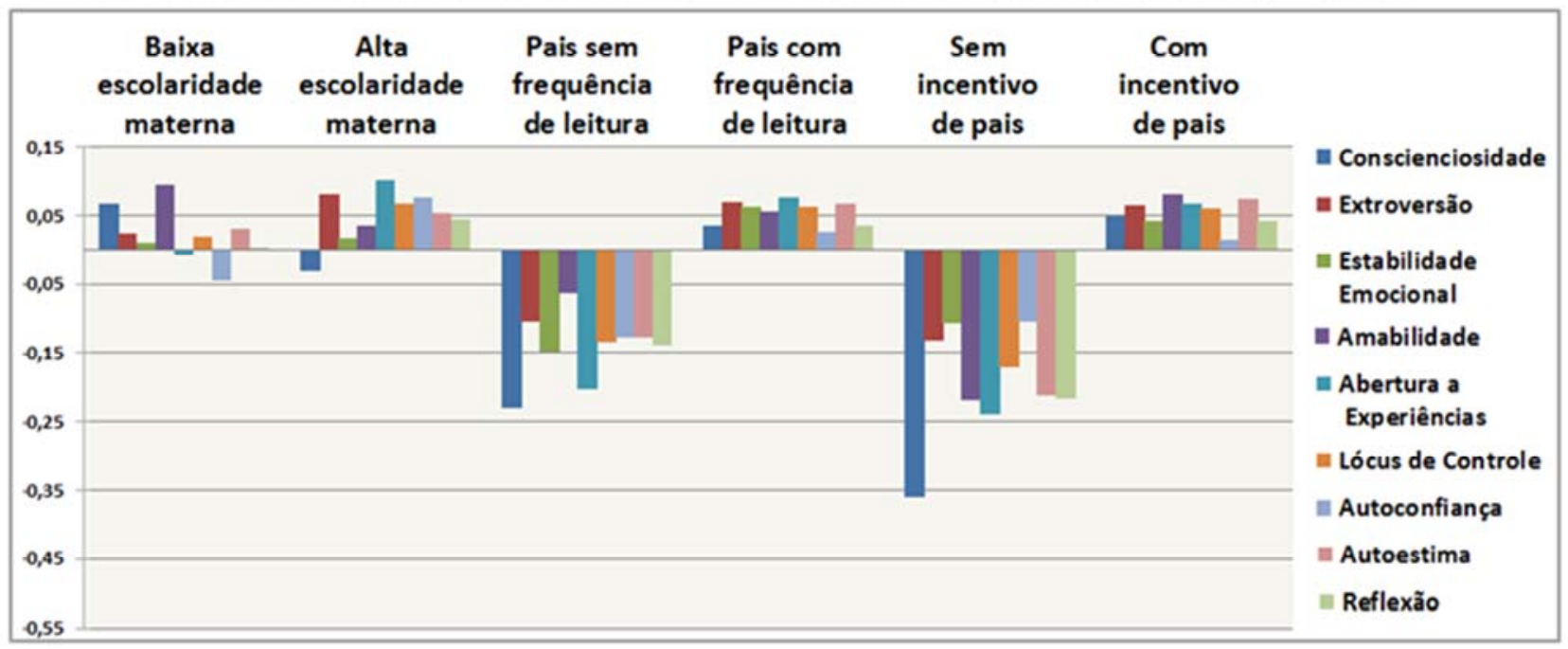

Fonte: Elaboração própria com uso de dados do Censo Escolar, Prova Brasil e microdados da pesquisa de campo realizada na rede estadual do Rio de Janeiro.

Olhando para os gráficos, percebe-se que as médias, de modo geral, são maiores para alunos de colégios com religiosidade, independente do subgrupo (mais ou menos favorecido). Por outro lado, é interessante verificar que alunos vulneráveis (em qualquer uma das 
dimensões) apresentam menores médias de atributos socioemocionais, sendo isso mais marcante no caso de falta de incentivo de pais. As discrepâncias entre as médias de cada grupo mais e menos vulnerável são menores, entretanto, na presença da religiosidade, o que sugere que esse contexto escolar favorece de forma mais expressiva alunos em condições desfavorecidas.

A seguir, prossegue-se à exposição dos resultados deste estudo.

\subsection{Resultados}

\subsubsection{Dados relacionados à amostra total de alunos}

Visando realizar uma análise preliminar dos dados referentes às habilidades socioemocionais da amostra total quando se considera o contexto escolar da religiosidade, efetivou-se um comparativo de diferenças de médias dos estudantes, mediante a aplicação do teste t de Student, para verificar as diferenças não cognitivas na ausência e presença desse contexto (gráfico 5).

Gráfico 5. Diferenças entre as médias de habilidades socioemocionais dos alunos na ausência e presença de religiosidade na escola

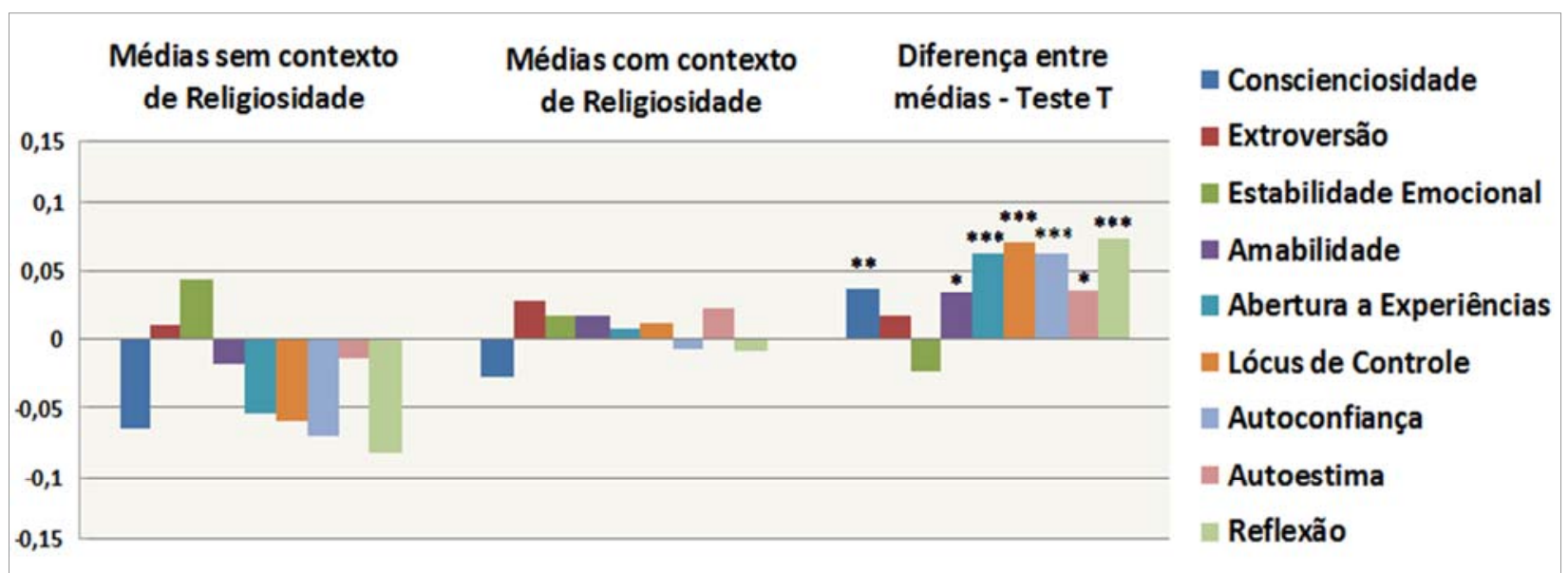

Fonte: Elaboração própria com uso de dados do Censo Escolar, Prova Brasil e microdados da pesquisa de campo realizada na rede estadual do Rio de Janeiro.

Nota: ${ }^{* * *}$ Significante a $1 \% ; *$ Significante a $5 \% ; *$ Significante a $10 \%$

Como se pode ver, há aumentos significativos nas médias de conscienciosidade, abertura a experiências, lócus de controle, autoconfiança e reflexão, sendo a 10\% significante na amabilidade e na autoestima. Os resultados em relação à extroversão e estabilidade emocional não apresentam significância estatística. 
Em continuidade, expõem-se os resultados da equação (1), usando os métodos de MQO para diferentes especificações, na tabela 5. As variáveis de controle utilizadas para cada modelo foram apresentadas na seção de metodologia e englobam características individuais dos estudantes, ambiente familiar, status socioeconômico e características da escola.

Tabela 5. Estimativa dos efeitos do contexto de religiosidade nas habilidades socioemocionais

\begin{tabular}{|c|c|c|c|c|}
\hline \multirow[b]{2}{*}{ Variáveis y } & \multicolumn{4}{|c|}{ Modelos } \\
\hline & $\begin{array}{l}\text { Variáveis } \\
\text { individuais }\end{array}$ & $\begin{array}{c}\text { Modelo } 1+ \\
\text { variáveis familiares }\end{array}$ & $\begin{array}{c}\text { Modelo } 2+ \\
\text { status } \\
\text { socioeconômico }\end{array}$ & $\begin{array}{c}\text { Modelo } 3+ \\
\text { variáveis } \\
\text { escolares }\end{array}$ \\
\hline Conscienciosidade & 0,021 & 0,030 & 0,022 & $0,038^{*}$ \\
\hline Extroversão & 0,021 & 0,025 & 0,032 & 0,019 \\
\hline Estabilidade Emocional & $-0,012$ & $-0,007$ & $-0,005$ & $-0,001$ \\
\hline Amabilidade & 0,0251 & $0,034^{*}$ & $0,034^{*}$ & $0,034^{*}$ \\
\hline Abertura a Experiências & $0,066^{\star * *}$ & $0,072^{\star \star *}$ & $0,072^{\star \star \star}$ & $0,062^{\star \star \star}$ \\
\hline Lócus Controle Interno & $0,055^{\star \star *}$ & $0,057^{* * *}$ & $0,054^{\star \star \star}$ & $0,055^{\star \star *}$ \\
\hline Autoconfiança & $0,061^{\star \star *}$ & $0,065^{\star * *}$ & $0,062^{\star * *}$ & $0,054^{* *}$ \\
\hline Autoestima & 0,031 & $0,036^{*}$ & $0,035^{*}$ & $0,044^{* *}$ \\
\hline Reflexão & $0,067^{\star \star \star}$ & $0,076^{\star \star \star}$ & $0,082^{\star \star *}$ & $0,076^{\star \star *}$ \\
\hline
\end{tabular}

Fonte: Elaboração própria. Nota: ***Significante a 1\%; ** Significante a 5\%; * Significante a 10\%.

Nesta tabela, poderiam ser ressaltados os aumentos em relação à abertura a experiências, lócus de controle, autoconfiança e reflexão, que mostram coeficientes positivos e com alto grau de significância em todos os modelos testados.

\subsubsection{Dados relacionados aos alunos de acordo com subgrupos de vulnerabilidade}

Antes de iniciar as análises dos resultados de acordo com diferentes vulnerabilidades dos alunos, convém ressaltar, de forma resumida, que os três grandes grupos se peculiarizam em algumas questões: a dimensão da escolaridade materna é a que capta um maior número de limitações, além de mais variadas, por refletir também o status socioeconômico dos estudantes; a frequência de leitura está associada especialmente a aspectos relacionados ao capital cultural da família e à abertura de experiências dos pais (o que exerce influências sobre os filhos); por fim, o incentivo de pais se diferencia dos outros grupos fundamentalmente pela motivação extrínseca ao estudo e por questões que evocam a relação psicoafetiva entre pais e filhos. 
Cabe informar, também, que serão realizados alguns apontamentos básicos após a exposição de cada tabela desta seção, reservando uma análise mais aprofundada para a seção posterior, onde se apresentam os resultados de forma gráfica para facilitar as análises.

A seguir, apresentam-se os resultados de alunos com mães de baixa e alta escolaridade.

Tabela 6. Estimativa dos efeitos do contexto de religiosidade nas habilidades socioemocionais de alunos conforme a escolaridade da mãe

\begin{tabular}{|c|c|c|c|c|c|c|c|c|}
\hline \multirow[b]{2}{*}{ Variáveis y } & \multicolumn{4}{|c|}{ Alunos com mães de baixa escolaridade } & \multicolumn{4}{|c|}{ Alunos com mães de alta escolaridade } \\
\hline & $\begin{array}{l}\text { Variáveis } \\
\text { individuais }\end{array}$ & $\begin{array}{l}\text { Modelo 1+ } \\
\text { Variáveis } \\
\text { familiares }\end{array}$ & $\begin{array}{l}\text { Modelo 2 + } \\
\text { Status } \\
\text { socioecon. }\end{array}$ & $\begin{array}{c}\text { Modelo 3+ } \\
\text { Variáveis } \\
\text { escolares }\end{array}$ & $\begin{array}{l}\text { Variáveis } \\
\text { individuais }\end{array}$ & $\begin{array}{l}\text { Modelo 1+ } \\
\text { Variáveis } \\
\text { familiares }\end{array}$ & $\begin{array}{l}\text { Modelo 2+ } \\
\text { Status } \\
\text { socioecon. }\end{array}$ & $\begin{array}{l}\text { Modelo 3+ } \\
\text { Variáveis } \\
\text { escolares }\end{array}$ \\
\hline Conscienciosidade & $0,148 * * *$ & $0,141^{\star * *}$ & $0,134^{\star * *}$ & $0,151^{\star \star *}$ & $-0,016$ & $-0,009$ & $-0,016$ & $-0,008$ \\
\hline Extroversão & $0,090^{* *}$ & $0,089 * *$ & $0,076^{\star *}$ & $0,067^{*}$ & $-0,010$ & 0,002 & 0,014 & 0,012 \\
\hline Estab. Emocional & 0,044 & 0,045 & 0,044 & 0,057 & $-0,038$ & $-0,031$ & $-0,024$ & $-0,022$ \\
\hline Amabilidade & $0,072^{*}$ & $0,074^{\star *}$ & 0,053 & 0,059 & 0,017 & 0,022 & 0,031 & 0,030 \\
\hline Abertura a Exp. & $0,109 * * *$ & $0,106^{\star * \star}$ & $0,103^{* * *}$ & $0,101^{* *}$ & $0,056^{*}$ & $0,074^{* *}$ & $0,075^{* *}$ & $0,065^{* *}$ \\
\hline Lócus de Controle & $0,109 * \star \star$ & $0,109 * * *$ & $0,104^{\star * *}$ & $0,110^{\star \star *}$ & $0,050^{*}$ & $0,053^{*}$ & 0,050 & 0,043 \\
\hline Autoconfiança & $0,105^{\star \star *}$ & $0,112^{\star \star *}$ & $0,119 * * *$ & $0,125^{\star \star *}$ & $0,080 * \star *$ & $0,079 * *$ & $0,071^{\star *}$ & $0,062^{*}$ \\
\hline Autoestima & $0,105^{\star * *}$ & $0,100 * * *$ & $0,088^{* *}$ & $0,102^{* *}$ & 0,006 & 0,015 & 0,015 & 0,016 \\
\hline Reflexão & $0,096^{\star *}$ & $0,097^{* *}$ & $0,104^{\star *}$ & $0,099 * *$ & $0,076^{\star *}$ & $0,090 * * *$ & $0,100 * \star *$ & $0,096^{\star * *}$ \\
\hline
\end{tabular}

Fonte: Elaboração própria. Nota: ***Significante a 1\%; ** Significante a 5\%; * Significante a 10\%.

Como se pode verificar, os alunos com baixa escolaridade materna apresentam maiores benefícios no seu desenvolvimento socioemocional do que os demais alunos, pois além de exibirem mais efeitos positivos significativos, suas magnitudes também se mostram maiores em todas as habilidades mensuradas.

Apoiando-se no fato dessa dimensão refletir também o status socioeconômico do aluno e de que tem sido feitos apelos por parte de organizações mundiais (OCDE, 2015) sobre como as disparidades de gênero são maiores (e, portanto, também suas consequências) entre os menos favorecidos economicamente, foram realizados os mesmos cálculos para meninos e meninas cujas mães possuem baixa escolaridade (tabela 7). 
Tabela 7. Estimativa dos efeitos do contexto de religiosidade nas habilidades socioemocionais de meninos e meninas com mães de baixa escolaridade

\begin{tabular}{|c|c|c|c|c|c|c|c|c|}
\hline \multirow[b]{2}{*}{ Variáveis y } & \multicolumn{4}{|c|}{ Meninos com mães de baixa escolaridade } & \multicolumn{4}{|c|}{ Meninas com mães de baixa escolaridade } \\
\hline & $\begin{array}{l}\text { Variáveis } \\
\text { individuais }\end{array}$ & $\begin{array}{c}\text { Modelo 1+ } \\
\text { Variáveis } \\
\text { familiares }\end{array}$ & $\begin{array}{l}\text { Modelo 2+ } \\
\text { Status } \\
\text { socioecon. }\end{array}$ & $\begin{array}{c}\text { Modelo 3+ } \\
\text { Variáveis } \\
\text { escolares }\end{array}$ & $\begin{array}{l}\text { Variáveis } \\
\text { individuais }\end{array}$ & $\begin{array}{c}\text { Modelo 1+ } \\
\text { Variáveis } \\
\text { familiares }\end{array}$ & $\begin{array}{l}\text { Modelo 2+ } \\
\text { Status } \\
\text { socioecon. }\end{array}$ & $\begin{array}{c}\text { Modelo 3+ } \\
\text { Variáveis } \\
\text { escolares }\end{array}$ \\
\hline Conscienciosidade & $0,165^{\star * *}$ & $0,163^{* * *}$ & $0,171^{* * *}$ & $0,195^{\star * *}$ & $0,145^{\star * *}$ & $0,140 * * *$ & $0,127^{* *}$ & $0,138^{\star * *}$ \\
\hline Extroversão & $0,179 * \star *$ & $0,179 * * *$ & $0,146 * *$ & $0,168^{* * *}$ & 0,0270 & 0,032 & 0,030 & 0,009 \\
\hline Estab. Emocional & $-0,014$ & $-0,030$ & $-0,018$ & $-0,014$ & $0,087^{*}$ & $0,103^{* *}$ & $0,097^{*}$ & $0,113^{* *}$ \\
\hline Amabilidade & $0,098^{*}$ & $0,102^{*}$ & 0,097 & 0,096 & 0,058 & 0,061 & 0,032 & 0,042 \\
\hline Abertura a Exp. & $0,140 * *$ & $0,128^{* *}$ & $0,128^{* *}$ & $0,151^{* *}$ & $0,091^{*}$ & $0,093^{* *}$ & $0,088^{*}$ & 0,068 \\
\hline Lócus de Controle & $0,108^{* *}$ & $0,106^{*}$ & $0,110^{*}$ & $0,108^{*}$ & $0,112^{\star \star}$ & $0,115^{\star *}$ & $0,107^{* *}$ & $0,120^{* *}$ \\
\hline Autoconfiança & 0,088 & 0,090 & 0,083 & 0,093 & $0,121^{* *}$ & $0,133^{* *}$ & $0,150 * * *$ & $0,157^{\star \star *}$ \\
\hline Autoestima & 0,084 & 0,081 & 0,085 & 0,094 & $0,122^{* *}$ & $0,122^{* *}$ & $0,102^{*}$ & $0,117^{* *}$ \\
\hline Reflexão & $0,143^{* *}$ & $0,152^{* *}$ & $0,169 * *$ & $0,189 * \star *$ & 0,070 & 0,061 & 0,060 & 0,037 \\
\hline
\end{tabular}

Fonte: Elaboração própria. Nota: ***Significante a $1 \%$; ** Significante a 5\%; * Significante a 10\%.

Interessante avaliar as diferenças nos efeitos por habilidade. Quando se analisam as características relacionadas aos pontos fracos de cada um, conforme apontado pela literatura, percebe-se que os benefícios se direcionam para algumas vulnerabilidades específicas de cada sexo. Uma consideração principal pode ser feita em relação ao tema do autoconceito feminino: tem-se constatado de forma recorrente fragilidades no público feminino quando se tratam de questões relacionadas a esse tema, mesmo que tenham muitas vezes desempenhos superiores aos dos homens, chegando-se a usar o termo "Gender Confidence Gap", pois homens normalmente manifestam níveis mais elevados neste quesito (The New York Times, 2015; BLAU, KAHN, 2016). Em troca, a tabela 8 exibe efeitos maiores e mais significantes para as meninas em termos de todas as medidas de autoconceito (lócus de controle, autoconfiança e autoestima).

Tabela 8. Estimativa dos efeitos do contexto de religiosidade nas habilidades socioemocionais de alunos divididos de acordo com a frequência de leitura dos pais

\begin{tabular}{|c|c|c|c|c|c|c|c|c|}
\hline & \multicolumn{4}{|c|}{ Pais sem frequência de leitura } & \multicolumn{4}{|c|}{ Pais com frequência de leitura } \\
\hline Variáveis y & $\begin{array}{l}\text { Variáveis } \\
\text { individuais }\end{array}$ & $\begin{array}{c}\text { Modelo 1 + } \\
\text { Variáveis } \\
\text { familiares } \\
\end{array}$ & $\begin{array}{c}\text { Modelo 2+ } \\
\text { Status } \\
\text { socioecon. }\end{array}$ & $\begin{array}{c}\text { Modelo 3+ } \\
\text { Variáveis } \\
\text { escolares } \\
\end{array}$ & $\begin{array}{l}\text { Variáveis } \\
\text { individuais }\end{array}$ & $\begin{array}{c}\text { Modelo 1+ } \\
\text { Variáveis } \\
\text { familiares } \\
\end{array}$ & $\begin{array}{c}\text { Modelo 2 + } \\
\text { Status } \\
\text { socioecon. }\end{array}$ & $\begin{array}{c}\text { Modelo 3+ } \\
\text { Variáveis } \\
\text { escolares } \\
\end{array}$ \\
\hline Conscienciosidade & $0,109^{* *}$ & $0,115^{\star \star *}$ & $0,107^{\star *}$ & $0,121^{* * *}$ & 0,007 & 0,008 & 0,001 & 0,018 \\
\hline Extroversão & 0,049 & 0,063 & 0,056 & 0,054 & 0,018 & 0,015 & 0,026 & 0,008 \\
\hline Estab. Emocional & $-0,024$ & $-0,016$ & $-0,013$ & $-0,002$ & $-0,008$ & $-0,004$ & $-0,002$ & 0,000 \\
\hline Amabilidade & 0,058 & 0,070 & 0,056 & 0,045 & 0,023 & 0,025 & 0,029 & 0,033 \\
\hline Abertura a Exp. & $0,136^{* * *}$ & $0,133^{\star \star *}$ & $0,131 * * \star$ & $0,121 * * *$ & $0,058^{\star * *}$ & $0,057^{\star *}$ & $0,058^{\star *}$ & $0,049^{* *}$ \\
\hline Lócus Controle & 0,058 & $0,071^{*}$ & 0,069 & 0,072 & $0,061 * * *$ & $0,056^{\star * *}$ & $0,052^{\star *}$ & $0,053^{* *}$ \\
\hline Autoconfiança & $0,111^{* *}$ & $0,123^{\star *}$ & $0,132^{\star * *}$ & $0,129 * *$ & $0,049^{* *}$ & $0,049 * *$ & $0,042^{*}$ & 0,033 \\
\hline Autoestima & 0,031 & 0,036 & 0,038 & 0,055 & 0,032 & $0,037^{*}$ & 0,034 & $0,041^{*}$ \\
\hline Reflexão & $0,164^{\star \star \star}$ & $0,160 * * *$ & $0,161^{\star \star \star}$ & $0,154^{\star \star *}$ & $0,050^{* *}$ & $0,054^{* *}$ & $0,062^{* * *}$ & $0,056^{* *}$ \\
\hline
\end{tabular}

Fonte: Elaboração própria. Nota: ***Significante a $1 \%$; * Significante a 5\%; * Significante a 10\%. 
Apesar das características que exibem efeitos significativos serem similares em quantidade nos dois subgrupos de acordo com a frequência de leitura de pais, é de se notar que o grupo menos favorecido apresenta, geralmente, magnitudes maiores nos coeficientes.

Tabela 9. Estimativa dos efeitos do contexto de religiosidade nas habilidades socioemocionais de alunos divididos de acordo com a presença ou ausência de incentivo de pais ao estudo

\begin{tabular}{|c|c|c|c|c|c|c|c|c|}
\hline & \multicolumn{4}{|c|}{ Sem incentivo de pais } & \multicolumn{4}{|c|}{ Com incentivo de pais } \\
\hline Variáveis y & $\begin{array}{l}\text { Variáveis } \\
\text { individuais }\end{array}$ & $\begin{array}{l}\text { Modelo 1+ } \\
\text { Variáveis } \\
\text { familiares }\end{array}$ & $\begin{array}{l}\text { Modelo 2+ } \\
\text { Status } \\
\text { socioecon. }\end{array}$ & $\begin{array}{l}\text { Modelo 3+ } \\
\text { Variáveis } \\
\text { escolares }\end{array}$ & $\begin{array}{l}\text { Variáveis } \\
\text { individuais }\end{array}$ & $\begin{array}{l}\text { Modelo 1+ } \\
\text { Variáveis } \\
\text { familiares }\end{array}$ & $\begin{array}{l}\text { Modelo 2+ } \\
\text { Status } \\
\text { socioecon. }\end{array}$ & $\begin{array}{l}\text { Modelo 3+ } \\
\text { Variáveis } \\
\text { escolares }\end{array}$ \\
\hline Conscienciosidade & $0,135^{\star \star \star}$ & $0,154^{\star \star \star}$ & $0,121^{\star *}$ & $0,118^{\star *}$ & 0,003 & 0,006 & 0,003 & 0,023 \\
\hline Extroversão & 0,038 & 0,051 & 0,054 & 0,045 & 0,019 & 0,021 & 0,030 & 0,016 \\
\hline Estab. Emocional & 0,005 & 0,020 & 0,028 & 0,012 & $-0,015$ & $-0,012$ & $-0,011$ & $-0,002$ \\
\hline Amabilidade & $-0,004$ & 0,008 & 0,002 & $-0,003$ & 0,032 & $0,042^{*}$ & $0,044^{\star *}$ & $0,045^{\star *}$ \\
\hline Abertura a Exp. & 0,071 & 0,071 & 0,054 & 0,049 & $0,071^{* \star *}$ & $0,072^{\star \star \star}$ & $0,076 * \star \star *$ & $0,066^{\star \star \star}$ \\
\hline Lócus Controle & $0,123^{* * *}$ & $0,143^{\star \star *}$ & $0,153^{* * *}$ & $0,140 * \star *$ & $0,044^{* *}$ & $0,040^{*}$ & 0,035 & $0,038^{*}$ \\
\hline Autoconfiança & 0,037 & 0,046 & 0,039 & 0,044 & $0,065^{\star \star \star}$ & $0,067^{\star \star \star}$ & $0,066^{* * *}$ & $0,056^{* *}$ \\
\hline Autoestima & 0,082 & $0,111^{\text {** }}$ & $0,120^{* *}$ & $0,114^{*}$ & 0,019 & 0,022 & 0,019 & 0,031 \\
\hline Reflexão & 0,051 & 0,049 & 0,052 & 0,062 & $0,078^{* \star *}$ & $0,080^{* * *}$ & $0,087^{\star \star *}$ & $0,077^{* \star *}$ \\
\hline
\end{tabular}

Fonte: Elaboração própria. Nota: ***Significante a $1 \%$; * Significante a 5\%; * Significante a 10\%.

Para analisar os dados da tabela 9, convém dizer que, de acordo com pesquisas, filhos de pais que demonstram interesse pelo seu estudo apresentam maiores índices de lócus de controle interno e autoestima do que os demais (FLOURI, 2006). Portanto, alunos que não recebem incentivos de seus pais teriam menos estímulos em relação a esses atributos socioemocionais. Quando se comparam os dois subgrupos, nota-se que o menos favorecido apresenta maiores incrementos concretamente nessas habilidades.

Por fim, considerando os resultados encontrados, os quais mostram efeitos maiores da religiosidade para grupos menos favorecidos, considerou-se oportuno realizar mais uma análise de dados para verificar se o efeito cresce com o aumento de vulnerabilidades do indivíduo. Criou-se uma variável para identificar os alunos mais vulneráveis entre os vulneráveis, o que equivale a um produto das condições "mães com baixa escolaridade", "pais sem frequência de leitura" e "sem incentivo de pais", todas variáveis dummy, assumindo, portanto, valor 1 para o caso do aluno reunir as três vulnerabilidades e 0 no caso de não se enquadrar nesse perfil.

Após realizar os cruzamentos e cálculos, verificou-se que, provavelmente por causa da redução expressiva de alunos encontrados no subgrupo com as três vulnerabilidades $(n=339)$, somente apresentaram significância estatística satisfatória os efeitos para três atributos 
socioemocionais (conscienciosidade, lócus de controle e autoconfiança). Por outro lado, é de se ressaltar os aumentos expressivos nos coeficientes destas habilidades. Além disso, em relação às demais competências, ainda que com efeitos não significativos, verifica-se um incremento em todos os coeficientes, quando se consideram as três vulnerabilidades em conjunto. Em outras palavras, quanto mais vulnerável o subgrupo, maior se apresenta o efeito do contexto escolar da religiosidade sobre as habilidades dos alunos.

Tabela 10. Estimativa dos efeitos do contexto de religiosidade nas habilidades socioemocionais de alunos com baixa escolaridade materna, pais sem frequência de leitura e sem incentivo de pais e dos pertencentes ao restante da amostra

\begin{tabular}{|c|c|c|c|c|c|c|c|c|}
\hline & \multicolumn{4}{|c|}{ Dummy com três vulnerabilidades $=1$} & \multicolumn{4}{|c|}{ Dummy com três vulnerabilidades $=0$} \\
\hline Variáveis y & $\begin{array}{l}\text { Variáveis } \\
\text { individuais }\end{array}$ & $\begin{array}{l}\text { Modelo } 1+ \\
\text { Variáveis } \\
\text { familiares }\end{array}$ & $\begin{array}{l}\text { Modelo 2+ } \\
\text { Status } \\
\text { socioecon. }\end{array}$ & $\begin{array}{c}\text { Modelo 3+ } \\
\text { Variáveis } \\
\text { escolares }\end{array}$ & $\begin{array}{l}\text { Variáveis } \\
\text { individuais }\end{array}$ & $\begin{array}{l}\text { Modelo 1+ } \\
\text { Variáveis } \\
\text { familiares }\end{array}$ & $\begin{array}{l}\text { Modelo 2+ } \\
\text { Status } \\
\text { socioecon. }\end{array}$ & $\begin{array}{c}\text { Modelo 3+ } \\
\text { Variáveis } \\
\text { escolares }\end{array}$ \\
\hline Conscienciosidade & $0,326^{* \star *}$ & $0,310^{* \star *}$ & $0,294^{\star \star *}$ & $0,280^{* *}$ & 0,024 & 0,031 & 0,026 & $0,040^{*}$ \\
\hline Extroversão & 0,070 & 0,072 & 0,060 & 0,081 & 0,014 & 0,017 & 0,020 & 0,008 \\
\hline Estab. Emocional & 0,157 & 0,164 & 0,134 & 0,154 & $-0,015$ & $-0,006$ & $-0,003$ & 0,002 \\
\hline Amabilidade & 0,100 & 0,131 & 0,078 & 0,062 & 0,028 & 0,033 & 0,033 & 0,035 \\
\hline Abertura a Exp. & 0,1825 & $0,201^{*}$ & 0,184 & 0,190 & 0,070 *** & $0,072^{\star \star *}$ & $0,072^{\star \star *}$ & $0,059 * \star *$ \\
\hline Lócus Controle & $0,350^{* * *}$ & $0,369 * \star *$ & $0,346^{* * *}$ & $0,336^{\star * *}$ & $0,042^{\star *}$ & $0,044^{* *}$ & $0,039^{*}$ & $0,039 *$ \\
\hline Autoconfiança & $0,223^{*}$ & $0,243^{*}$ & $0,281^{\text {** }}$ & $0,283^{* *}$ & $0,065^{\star \star *}$ & 0,069 *** & $0,068^{* * *}$ & $0,058^{* *}$ \\
\hline Autoestima & 0,191 & 0,194 & 0,154 & 0,156 & 0,028 & $0,037^{*}$ & 0,034 & $0,042^{*}$ \\
\hline Reflexão & 0,139 & 0,145 & 0,125 & 0,161 & $0,073^{\star \star \star}$ & $0,076^{\star \star *}$ & $0,085^{\star \star \star}$ & $0,074^{\star \star \star}$ \\
\hline
\end{tabular}

Fonte: Elaboração própria. Nota: ***Significante a 1\%; ** Significante a 5\%; * Significante a 10\%.

\subsubsection{Comparativo dos efeitos significativos de alunos por subgrupos}

A seguir, são resumidos, em forma de gráficos, os resultados das estimações MQO identificadas como estatisticamente significantes na amostra total e em cada subgrupo. $\mathrm{O}$ propósito é facilitar a comparação dos principais efeitos encontrados, ajudando a visualizar oportunidades de futuras pesquisas que se proponham a investigar os mecanismos pelos quais ocorrem essas variações. $\mathrm{Na}$ escolha dos coeficientes, foram adotados os resultantes do modelo longo. Abaixo, apresentam-se os principais efeitos em relação a alunos com mães de baixa escolaridade, de acordo com o sexo. 


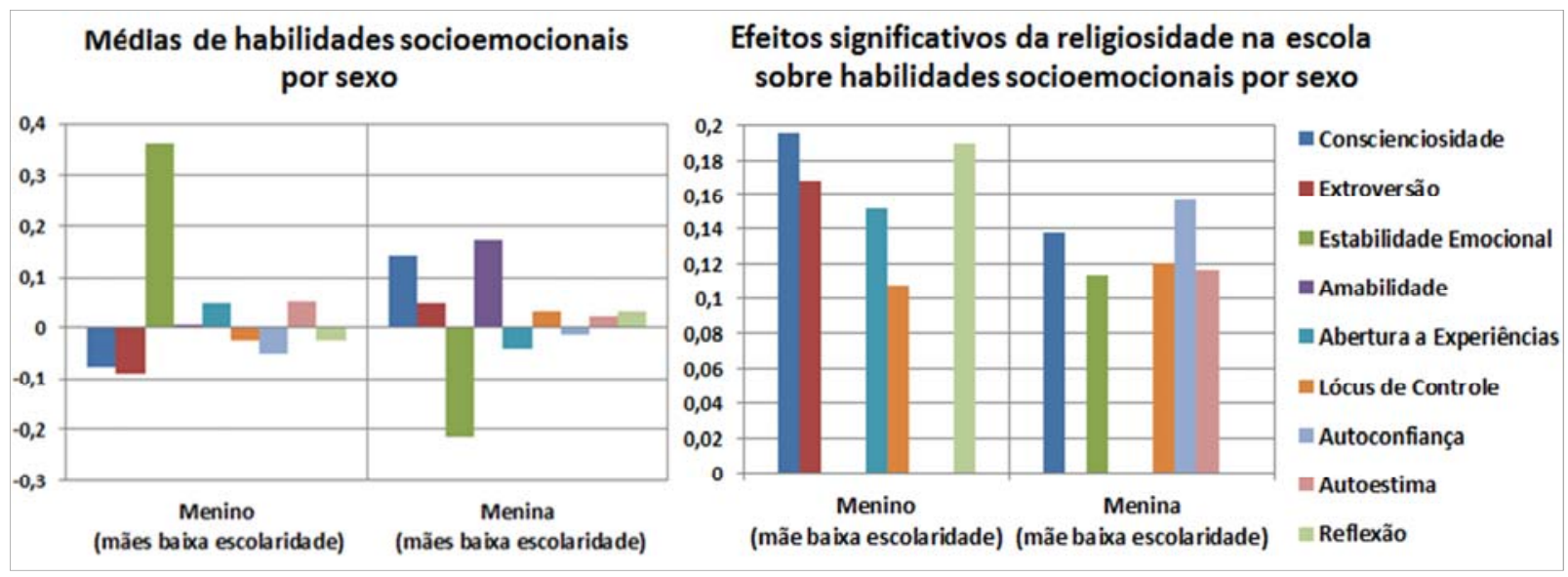

Gráfico 6. Habilidades socioemocionais por sexo: médias e efeitos da religiosidade na escola Fonte: Elaboração própria com uso de dados do Censo Escolar, Prova Brasil e microdados da pesquisa de campo realizada na rede estadual do Rio de Janeiro.

Primeiramente, são citados alguns achados da literatura que fundamentam a análise dos resultados. Estudos mostram que diferenças entre as características de personalidade entre os sexos são detectadas desde a primeira infância (ELSE-QUEST ET al, 2006; WILGENBUSCH, MERRELL, 1999) e permanecem relativamente constantes ao longo da vida adulta (FEINGOLD, 1994; MCCRAE, COSTA, 1984), além disso, há fatores familiares, educacionais e profissionais, entre outros, que podem favorecer ou prejudicar o funcionamento socioemocional de homens e mulheres.

Busca-se entender melhor o desenvolvimento masculino e feminino em aspectos neurológicos, psicológicos, sociológicos e assim por diante. Muitos pesquisadores visam compreender tais peculiaridades para atuar na diminuição de desigualdades como de renda (“gender wage gap"), desempenho educacional, autoconceito, etc. Um estudo de Schmitt et al. (2008), realizado com 17.637 pessoas de 55 países, verificou que mulheres reportam níveis mais altos de conscienciosidade, extroversão e amabilidade e mais baixos de estabilidade emocional. Por outro lado, outras pesquisas revelam maiores graus de lócus de controle, autoestima e autoconfiança por parte dos homens (BLAU, KAHN, 2016).

Neste sentido, são ressaltados alguns aspectos sobre os dados do gráfico 4, que apontam para um possível processo de substitutibilidade nos efeitos em meninos em meninas: a) as magnitudes dos efeitos são maiores para os meninos, público considerado mais deficiente em atributos socioemocionais, conforme citado; b) por outro lado, os dois principais campos onde elas apresentam deficiências em relação a eles (estabilidade emocional e autoestima/autoconfiança) exibem efeitos positivos e significativos somente para as meninas (apesar de também haver um efeito positivo na autoestima e autoconfiança dos 
meninos, não há significância estatística). Da mesma forma, a reflexão, normalmente mais relacionada ao público feminino, só mostra incrementos (significativos) para os meninos. Em suma, olhando-se detidamente para o gráfico, percebe-se que todos os gender gaps socioemocionais indicados pela literatura parecem diminuir na presença de práticas religiosas na escola.

Podem ser feitas algumas associações com os achados científicos, procurando entender os fatores que estão por trás de cada resultado.

No que tange aos aumentos nos níveis de conscienciosidade nos dois sexos, pode-se inferir que um dos canais por onde esse efeito esteja ocorrendo seja pelo aumento da conexão escolar (school connectedness) de meninos e meninas. Azagba et al (2014) investigaram a influência da religiosidade sobre essa variável em alunos de colégios públicos, por meio das perguntas "me sinto próximo das pessoas da minha escola", "estou feliz por estar na minha escola" e "me sinto seguro na minha escola" e verificaram que a importância da religião para a pessoa proporciona melhores conexões escolares tanto de homens como mulheres. Por outro lado, os dados sugerem uma influência mais abrangente da religiosidade em relação ao público feminino, uma vez que a outra variável independente avaliada, "frequência em serviços religiosos", só mostrou efeitos significativos para as meninas. Apesar disso, é interessante constatar que o gráfico exibe maiores aumentos na conscienciosidade de meninos do que de meninas. Isso pode estar ocorrendo porque normalmente elas já possuem maiores conexões escolares do que eles. A maior lacuna no público masculino pode estar contribuindo para um maior efeito nesse sentido.

Sobre os resultados em estabilidade emocional e lócus de controle, encontram-se pesquisas sobre a relação da religiosidade com habilidades de coping, que estão ligadas a atributos como estes. Um estudo de Krok (2015) identifica mecanismos referentes ao contexto ideológico mediando tais efeitos: é testada a mediação de duas variáveis relacionadas ao meaning-making (encontro de sentido) nos efeitos da religiosidade/espiritualidade $(\mathrm{R} / \mathrm{S})$ sobre características de coping de adolescentes e encontrados efeitos diretos e indiretos da R/S neste sentido, sendo que uma parcela de mediação é atribuída ao meaning-making, tanto global quanto situacional, para ambos os sexos. Esse pode ser um dos caminhos por onde esteja aumentando a estabilidade emocional das meninas, mais vulneráveis nesse aspecto e o lócus de controle de ambos os sexos.

Além disso, deduz-se que o processo descrito no parágrafo acima seja um dos mecanismos pelos quais a religiosidade diminui o número de suicídios no público feminino. Um estudo realizado por Donahue e Benson (1995) apresentou como principal fator preditor 
de suicídio o fato de ser menina. Em contrapartida, a religiosidade mostrou-se como o maior fator inibidor das duas dimensões do suicídio (idealização e concretização). Isso mostra que podem existir recursos específicos da religiosidade para compensar fragilidades femininas que se referem à depressão, que provavelmente vão além do contexto ideológico. Concretamente em relação ao aumento da estabilidade emocional e autoestima, atributos que se destacam como fatores de proteção em relação à depressão feminina, podem estar ocorrendo efeitos também pelos seguintes mecanismos da religiosidade (expostos na figura 2 deste trabalho): pelos fatores de "experiências espirituais" (que conferem conforto espiritual) e de "habilidades de coping" (que ajudam a lidar com o stress) e, ainda, pelos contextos social (relacionamentos que podem servir de apoio em momentos difíceis) e transcendente (que ajuda a adquirir perspectiva de distância em relação aos problemas, pela ponderação de que a vida não se reduz a isso, além de proporcionar um sentimento de saber-se escolhido ou amado por outro ser, o que confere forças psicoafetivas).

Outra consideração poderia ser feita sobre um campo que implica em carências para os dois sexos, mas que tem repercussões especiais para as mulheres quando o assunto é estabilidade emocional e medidas de autoconceito: as expectativas da sociedade. Conforme exposto por Bertrand (2011), psicólogos mostram que as pessoas esperam que as mulheres sejam dóceis e generosas e que os homens transpareçam segurança e assertividade. Além disso, há também exigências físicas, especialmente para meninas, que geram problemas para sua autoestima (CRIBB, HAASE, 2016). Uma das formas de investigar o quanto dessas exigências afeta o desenvolvimento é comparar caraterísticas de estudantes de colégios coeducacionais e single-sex (só de meninos ou meninas) onde, apesar de não se conseguir isolar totalmente o efeito da pressão de pares do sexo oposto (pois a convivência entre os sexos ocorre em outros ambientes, como atividades extraescolares, família etc.), verifica-se uma redução da mesma durante um período do dia (quando se está no colégio). Os resultados revelam diferenças cognitivas e socioemocionais entre os alunos dos dois tipos de escolas (MAEL, 1998, US DEPARTMENT OF EDUCATION, 2005, PARK, BEHRMAN, CHOI, 2013, ARTOLA, 2014), sendo que quando se avalia as causas para isso, expõem-se, sobretudo, questões referentes a peer effects (efeitos de pares) e code switching (socialização em contextos específicos, que se traduz em adaptação do comportamento ao ambiente) (US DEPARTMENT OF EDUCATION, 2008; CAMPS, 2015, AGUILÓ, 2015). Há mais de um mecanismo da religiosidade que pode atuar na compensação de pressões de pares, porém pode-se citar especialmente o contexto ideológico, que, pelo fortalecimento da identidade pessoal, age como fator de proteção em relação a demandas nocivas da sociedade. 
O próximo gráfico mostra os resultados comparando os subgrupos de acordo com as diferentes dimensões de vulnerabilidade.

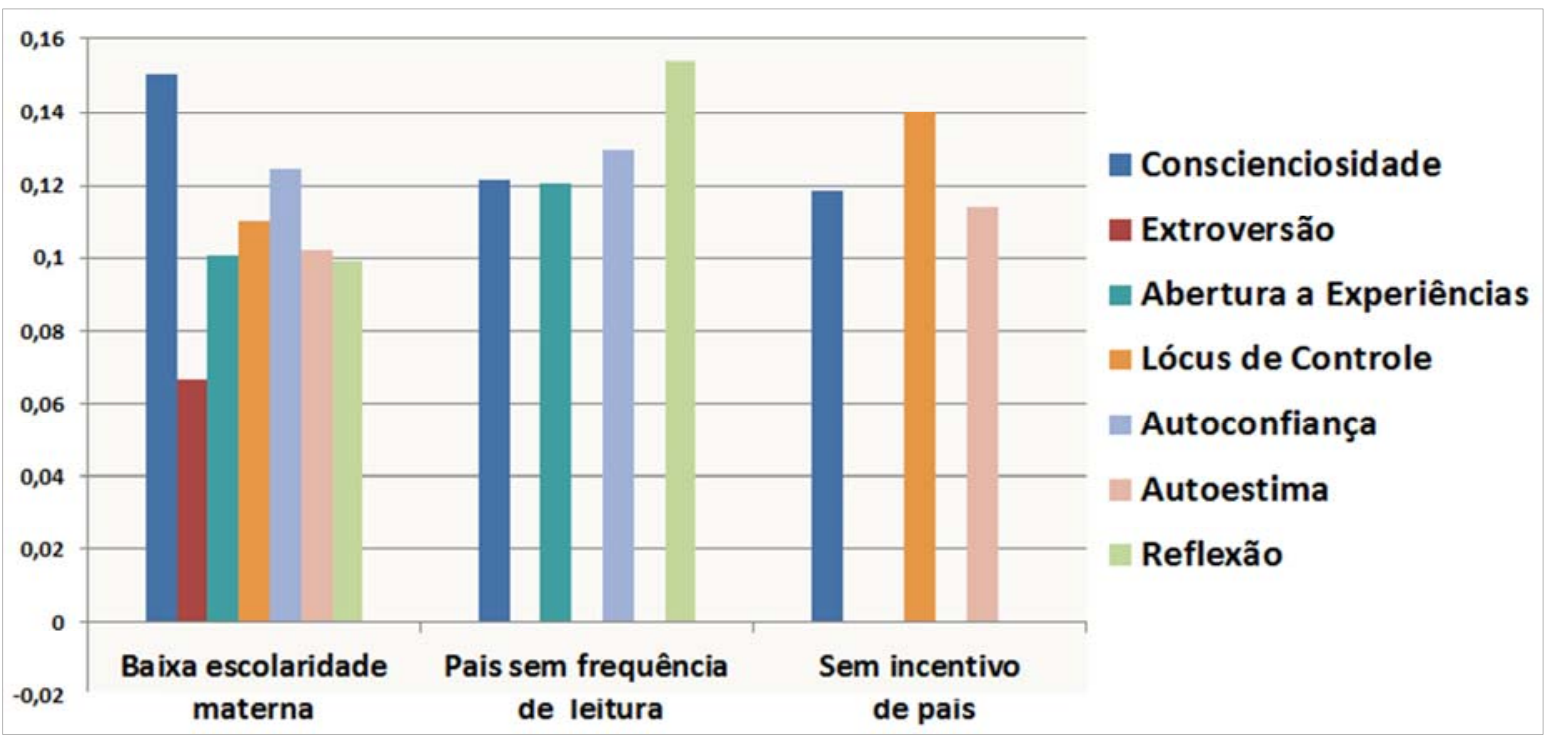

Gráfico 7. Efeitos da religiosidade na escola sobre as habilidades socioemocionais de alunos de subgrupos menos favorecidos

Fonte: Elaboração própria com uso de dados do Censo Escolar, Prova Brasil e microdados da pesquisa de campo realizada na rede estadual do Rio de Janeiro.

Uma consideração inicial que poderia ser feita é a de que os efeitos sobre as habilidades socioemocionais de grupos menos favorecidos são mais amplos no caso de alunos com baixa escolaridade materna. Uma possível explicação pode estar em que, como pode ser visto no comparativo entre essas três dimensões de vulnerabilidade (quadro 2), trata-se do subgrupo que, além de manifestar deficiências familiares, reflete também seu status socioeconômico, o que implica em uma série de limitações na vida do estudante (DUNCAN, BROOKS-GUNN, 2000), mais abrangentes do que as relacionadas somente ao âmbito familiar. Assim sendo, seriam mais áreas de carência onde a religiosidade poderia atuar pela via da substitutibilidade.

Há um dizer popular, encontrado em placas de caminhão, que expressa de forma coloquial um mecanismo pelo qual pode estar ocorrendo grande parte dos efeitos em alunos com poucos meios socioeconômicos: "não sou o dono do mundo, mas sou filho dele". Esse sentimento pode trazer consequências significativas para alguém que experimenta limitações na vida, conforme expresso a seguir.

Um primeiro aspecto diz respeito ao conforto na dor, o que pode ser proporcionado pelo canal de experiências espirituais (SMITH, 2003), que confere compensações como 
plenitude e paz. Juntamente, pode haver efeitos do contexto transcendente, pelo qual uma pessoa se sabe escolhida ou amada por um ser maior (no caso de religiões judaico-cristãs), o que, por sua vez, causa algo semelhante à presença de um pai ou mãe, que trazem consolo ao filho nas dificuldades.

Uma segunda questão reside no aumento da esperança, que gera ânimo e disposição para colocar os meios para procurar reverter a situação. Esse ponto de compensação pode estar atrelado a um fator e a dois contextos da religiosidade. Primeiramente ao contexto transcendente, pois quando se pondera que existe um ser superior com força e recursos onipotentes com o qual se pode contar, sente-se aumentada a própria capacidade de alcançar as metas na vida. A segunda fonte de esperança vem do contexto social e do fator de network closure, conceitos que se referem aos diferentes tipos de recursos proporcionados ao indivíduo pelo incremento de relações sociais e pela qualidade das mesmas, pois proporcionam relacionamentos baseados na confiança e ajuda interpessoal. O saber-se integrante de um grupo (pessoas que compartilham a mesma denominação religiosa) disposto a prestar apoio nas dificuldades também pode proporcionar uma maior segurança em relação às dificuldades do presente e do futuro.

O contexto ideológico confere um sentido maior para os acontecimentos da própria vida, ainda que pareçam adversos em algumas circunstâncias, ajudando a enfrentá-los em vez de retrair-se e deixar-se dominar por sentimentos de impotência e tristeza (aqui entra um dos campos mais pesquisados em relação à religiosidade, pois pesquisas mostram que diminui os índices de suicídio e depressão aguda). Esse aspecto está relacionado com aumentos no lócus de controle e na estabilidade emocional (apesar de que, neste trabalho, apesar dos efeitos sobre esta última habilidade exibirem coeficientes positivos para esse subgrupo, não se mostraram significantes).

Ainda poderiam ser citadas outras questões, como a relacionada à ampliação do capital cultural, especialmente de públicos desfavorecidos em termos socioeconômicos, por oportunidades proporcionadas no meio religioso de expandir sua cultura geral (conforme mecanismo proposto por Smith, exposto na figura 2). Como exemplo recente transmitido na mídia brasileira, está o caso de um trabalhador da lavoura de uma cidade do Ceará que ingressou no mundo da música a partir da oportunidade de tocar teclado na igreja e, posteriormente, interessou-se também por outros instrumentos. Após, começou a dar aulas de música e migrou para essa nova profissão, sendo atualmente maestro em um projeto social artístico da região (JORNAL NACIONAL, 2016). 
Em relação ao segundo subgrupo, de alunos cujos pais não têm frequência de leitura, destacam-se os maiores aumentos em abertura a experiências e reflexão quando comparados aos demais. Para aprofundar no que significa a vulnerabilidade de não se ter hábitos de leitura em casa e como pode estar ocorrendo o processo de substitutibilidade por parte da religiosidade, convém recordar alguns achados científicos e, então, fazer alguns apontamentos:

a) Pesquisas mostram que hábitos de leitura estão associados à abertura a experiências (KRAAYKAMP, VAN EIJCK, 2005). Sendo provável que pais com frequência de leitura tenham maiores níveis dessa habilidade, deduz-se que isso terá repercussões para os filhos, uma vez que as características não cognitivas dos pais exercem influência sobre o seu desenvolvimento (OLIVER et al, 2009).

b) Além disso, maiores níveis de abertura a experiências geram efeitos positivos sobre participação em atividades culturais, o que sugere que pais mais dotados dessa habilidade proporcionam um maior capital cultural aos seus filhos.

c) A presença de um role model em relação ao hábito de leitura pode ser benéfica para a criança ou adolescente na medida em que apresenta esse costume como algo bom, pertencente à rotina do dia a dia, podendo estimular, assim, um comportamento de emulação. Segundo Villiger et al. (2012), com base em uma teoria cognitivopsicológica, "ler" pode ser entendido como um processo ativo, onde a pessoa procura combinar a informação do texto com os conhecimentos prévios que possui (VAN DIJK, KINTSCH, 1983), sendo o processo de leitura algo altamente complexo, que envolve interagir subprocessos na palavra, sentença e texto. Portanto, estimular, ainda que indiretamente, a leitura no filho pode melhorar processos relacionados a pensamento crítico, reflexão, raciocínio abstrato e lógico, entre outros.

d) Por outro lado, intervenções voltadas para promover a motivação intrínseca para a leitura mostraram efeitos positivos e significativos em aspectos como curiosidade e autoeficácia dos alunos (GUTHRIE et al, 2005; GUTHRIE et al., 2007).

e) Esse panorama sugere que filhos de pais que não possuem hábitos de leitura podem ser menos favorecidos em termos de habilidades como abertura a experiências, curiosidade, reflexão, raciocínio abstrato, entre outros, além de um menor capital cultural, por terem menos estímulos neste sentido.

f) Em contrapartida, o gráfico 7 sugere claramente uma influência por parte da religiosidade na escola por meio da via de substitutibilidade, uma vez que proporciona aumentos significativos especificamente na abertura a experiências e na 
reflexão de alunos cujos pais não têm frequência de leitura. $\mathrm{O}$ mais interessante talvez seja que são os maiores aumentos nesses dois atributos, quando se olha para os alunos com outros tipos de vulnerabilidades.

g) Para compreender o canal por onde esse efeito acontece, pode-se mencionar um dos mecanismos de influência da religiosidade proposta por Smith (2003), exposto na figura 2: o incremento do capital cultural, ao proporcionar ao aluno oportunidades alternativas de aquisição de cultura geral e conhecimentos sobre questões diversas, além do conteúdo normalmente proporcionado em âmbito escolar. Além disso, pode estar havendo compensações por meio do fator role model, mediante figuras ou pessoas que estimulem a motivação ao aprendizado.

Em relação aos efeitos sobre alunos sem incentivos de pais, pode-se considerar que:

a) A principal peculiaridade dessa dimensão remete à figura dos pais na vida de uma pessoa, pois captura o envolvimento e interesse deles pelos filhos, o que evoca uma série de questões, como role models, relações psicoafetivas, ajustamento social e emocional.

b) As duas características socioemocionais mais mencionadas por pesquisas como relacionadas ao envolvimento de pais no estudo dos filhos são a conscienciosidade e o lócus de controle (GROLNICK, SLOWIACZEK, 1994; POMERANTZ et al, 2007). Por outro lado, a autoestima também tem sido apontada como associada a essa variável familiar (FLOURI, 2006). Portanto, estudantes sem incentivo de pais estão mais sujeitos a terem essas habilidades menos desenvolvidas. Interessante verificar que o gráfico mostra aumentos significativos nesses três aspectos quando há religiosidade na escola.

c) O processo de substitutibilidade apresenta-se de forma bastante "previsível" no aumento da conscienciosidade, pois a principal consequência do incentivo ao estudo por parte dos pais é, justamente, o maior esforço e comprometimento acadêmico dos filhos (aspectos relacionados à conscienciosidade). Entende-se, portanto, que a principal carência desses estudantes está na falta de uma motivação extrínseca ao estudo, que estimule a conscienciosidade e demais questões relacionadas ao âmbito acadêmico.

d) O crescimento na autoestima pode estar relacionado ao contexto transcendente proposto por King (2008), onde se menciona que, por meio da religiosidade/espiritualidade, a pessoa se sente amada e valorizada por outro, o que 
está diretamente relacionado à autoestima individual (BLASCOVICH, TOMAKA, 1991). Filhos de pais que não se interessam por seus estudos podem ser mais propensos à percepção de serem pouco queridos ou de terem menos valor (POMERANTZ, 2007), o que seria amenizado por este mecanismo.

e) É provável que pelo mesmo contexto (transcendente) esteja ocorrendo o incremento do lócus de controle, porém por outro canal: uma vez que filhos de pais ausentes exibem menos sentimentos de controle sobre suas vidas (pois não se veem amparados pelo apoio de alguém com mais recursos), ter a convicção de que um ser mais poderoso está, não somente interessado, mas ativamente empenhado em ajudá-lo pode conferir uma maior segurança em relação às próprias conquistas futuras, pois se tem a esperança desse apoio nas incertezas e eventuais dificuldades da vida. No caso de religiões cristãs, a compensação da figura paterna chega a ser verbalizada por meio de expressões comumente usadas, como "filiação divina" e a oração do "Pai nosso".

f) Além disso, o lócus de controle pode também estar sendo estimulado por meio de uma compensação causada pela religiosidade em termos de motivação intrínseca. Trata-se de uma faceta desse atributo socioemocional que está associada ao envolvimento de pais na vida acadêmica dos filhos: alunos sem incentivos de pais apresentam menores motivações intrínsecas ao estudo (e, assim, menores índices de lócus de controle). Pesquisas mostram que um maior envolvimento em atividades religiosas aumenta a motivação ao estudo de alunos de colégios públicos (REGNERUS, 2000). Procurando entender por onde ocorrem os efeitos da religiosidade neste caso, pode-se remeter ao contexto ideológico, que implica em questões empregadas na teoria motivacional: favorecendo o processo de formulação e encontro de significado e propósito, ajuda-se o aluno a elaborar um sentido para as ações de sua vida (nessa circunstância, o estudo), de forma a querer se comprometer com as mesmas por enxergar algo maior por trás. 
Na sequência, faz-se um comparativo dos efeitos entre os subgrupos mais favorecidos em termos de escolaridade da mãe, ambiente familiar de leitura e envolvimento de pais.

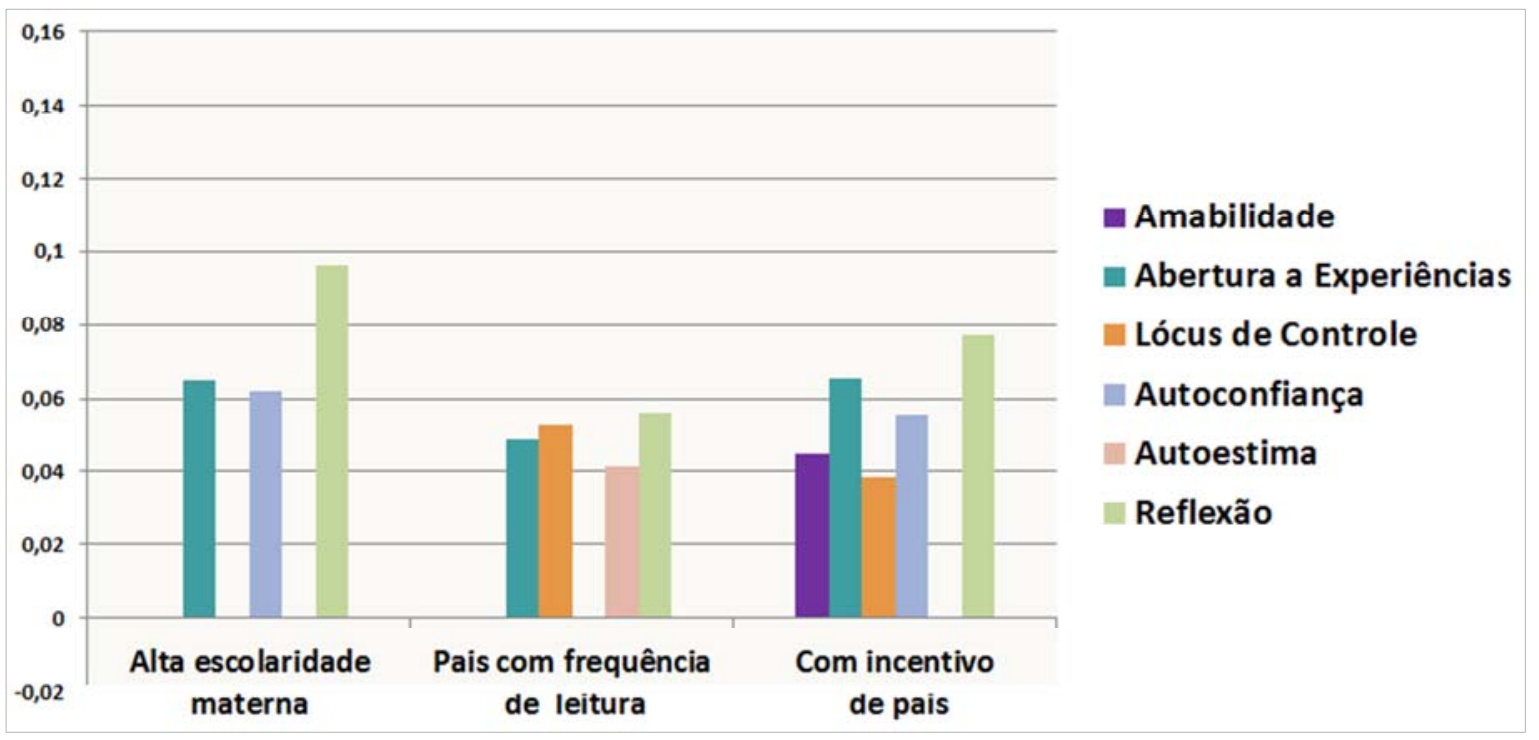

Gráfico 8. Efeitos da religiosidade na escola sobre as habilidades socioemocionais de alunos de subgrupos mais favorecidos

Fonte: Elaboração própria com uso de dados do Censo Escolar, Prova Brasil e microdados da pesquisa de campo realizada na rede estadual do Rio de Janeiro.

Uma consideração que se poderia fazer é a de que as magnitudes de praticamente todos os efeitos significativos são menores do que os efeitos encontrados nos subgrupos mais vulneráveis (a única exceção ocorre para o coeficiente da reflexão, que supera em dois casos o menor do outro subgrupo, a extroversão). Esse fato está em consonância com resultados de pesquisas que mostram que indivíduos com menos estruturas de suporte em casa ou na escola apresentam maiores impactos por parte da religiosidade, o que pode estar ligado a uma melhora nos recursos sociais e psicológicos que esta proporciona (COOLEY FRUEHWIRTH et al, 2016).

Interessante, também, constatar que nenhum dos subgrupos apresenta aumento significativo na conscienciosidade, como ocorre nos desfavorecidos, e que as variáveis que apresentam crescimentos em todos os casos são a abertura a experiências e a reflexão.

O gráfico a seguir tem por objetivo facilitar a análise de como as habilidades que se mostraram mais associadas à religiosidade neste estudo (conscienciosidade, abertura a experiências e lócus de controle) exibem efeitos significativos em cada subgrupo mais e menos favorecido de cada dimensão de vulnerabilidade. Neste caso, optou-se por não incluir as facetas que se destacaram (autoconfiança, autoestima e reflexão) porque o intuito é avaliar o resultado com base na literatura, que oferece mais subsídios em relação às três primeiras, além disso, podem-se visualizar os efeitos sobre as facetas nos gráficos já expostos. 


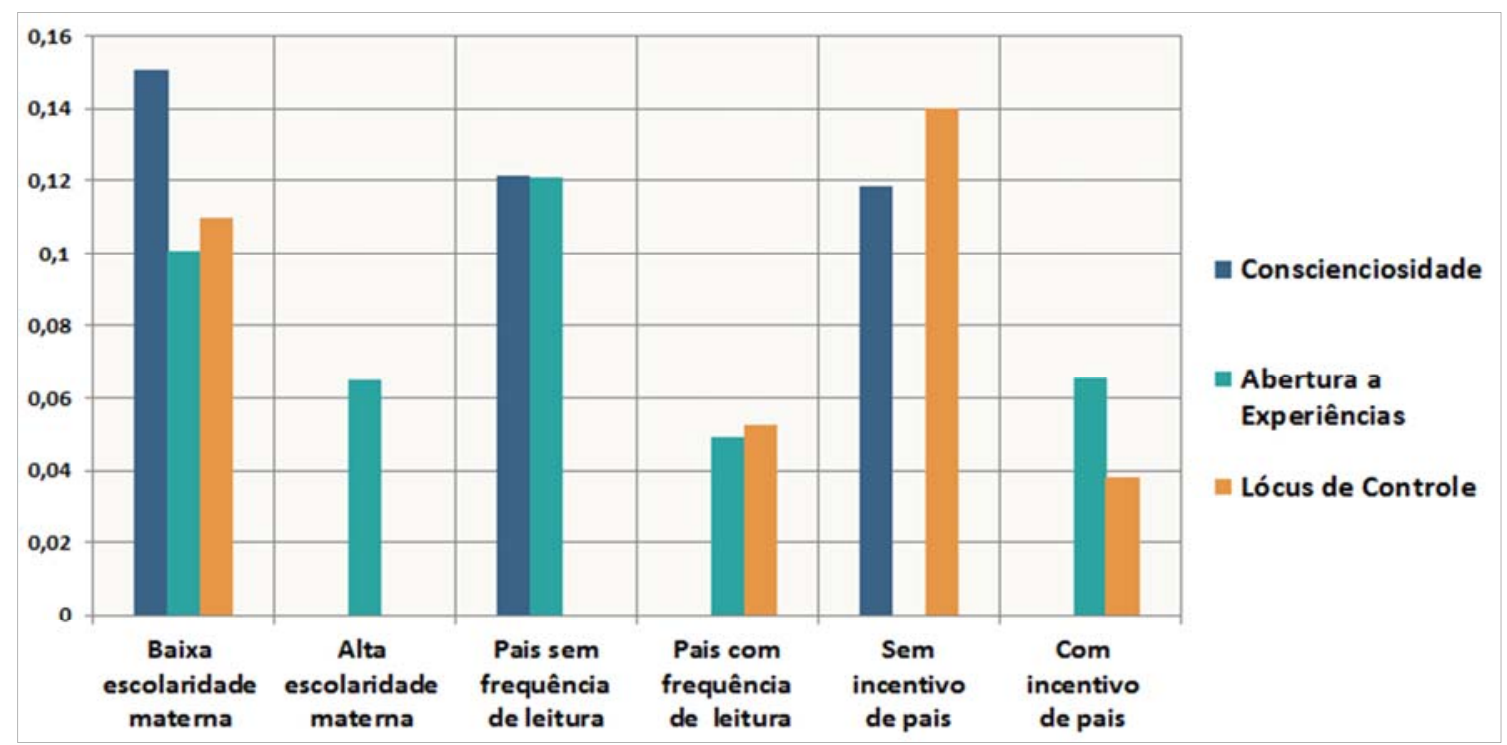

Gráfico 9. Comparativo dos efeitos da religiosidade na escola sobre a conscienciosidade, abertura a experiências e lócus de controle de grupos menos e mais favorecidos.

Fonte: Elaboração própria com uso de dados do Censo Escolar, Prova Brasil e microdados da pesquisa de campo realizada na rede estadual do Rio de Janeiro.

Interessante ver que em todos os subgrupos menos favorecidos repete-se um aumento na conscienciosidade (o que não ocorre para os mais favorecidos), sendo que esta é a característica que mais tem sido relacionada com o desempenho acadêmico. Talvez esse seja um dos motivos para a identificação de efeitos positivos da religiosidade no rendimento escolar de alunos mais vulneráveis.

Por outro lado, verificam-se incrementos na abertura a experiências de todos os subgrupos, mais e menos favorecidos, com exceção somente do subgrupo sem incentivo de pais. Isso remete a duas considerações principais: a) observar que se trata da habilidade socioemocional onde a religiosidade exerce efeitos de forma mais abrangente, uma vez que gera benefícios em praticamente todos os perfis de alunos; b) um segundo apontamento diz respeito à maleabilidade dos atributos não cognitivos ao longo do ciclo de vida, conforme exposto a seguir.

De acordo com os dados expostos por Roberts e Vietchbauer (conforme figura 3), a idade de 10 a 20 anos compreende o período de maior crescimento em abertura a experiências na vida de uma pessoa, ao passo que o inverso acontece com a conscienciosidade, pois é quando menos se evolui neste atributo. Com isso, compreende-se melhor porque, mediante um estímulo favorável (neste caso, a religiosidade na escola), praticamente todos os subgrupos apresentem aumentos na abertura a experiências. Em relação à conscienciosidade, por mostrar menos maleabilidade de desenvolvimento neste período, entende-se que seja mais difícil de ser desenvolvida, ainda na presença de um estímulo. Fica, portanto, mais evidente o 
maior efeito desse contexto escolar sobre grupos desfavorecidos, porque apresentam incrementos nesse atributo e, ainda, com magnitudes maiores do que as exibidas por alunos de grupos favorecidos no que diz respeito à sua abertura a experiências.
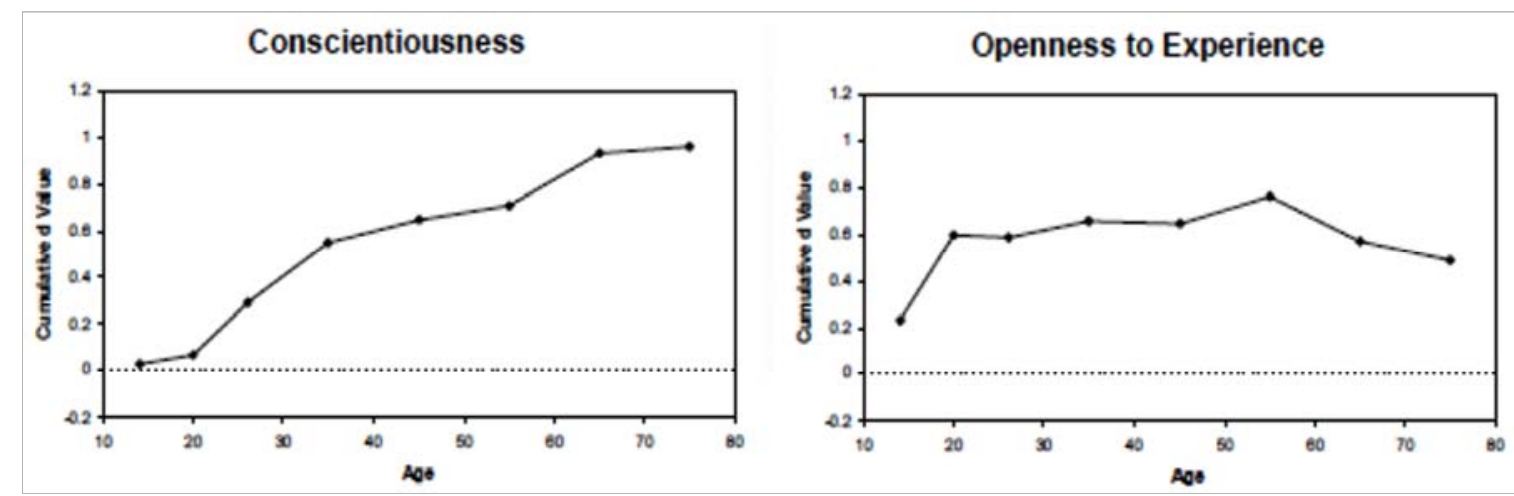

Figura 3. Mudanças acumuladas no nível médio de personalidade ao longo do ciclo de vida Fonte: Roberts, Walton e Vietchbauer (2006), citado em Duckworth et al (2011).

Permanece a dúvida, porém, de porque alunos sem incentivo de pais não crescem em abertura a experiências, ao contrário dos demais. Uma possível explicação para isso pode estar fundamentada na teoria sobre a tecnologia de formação de habilidades cognitivas e não cognitivas, proposta por Cunha e Heckman (2007). Os autores demonstram que habilidades produzidas em um estágio aumentam o grau das alcançadas em etapas posteriores. Este efeito é chamado de autoprodutividade, segundo o qual as habilidades adquiridas em um período persistem em períodos futuros e produzem um auto reforço (um maior estoque de habilidades em um período aumenta o estoque de habilidades no próximo período), além de beneficiar o desenvolvimento de outras competências. Denomina-se de complementaridade dinâmica o fenômeno de que habilidades produzidas em um estágio elevam a produtividade do investimento em estágios posteriores (pois facilitam a assimilação de outras no futuro). Nos gráficos 3 e 4 deste trabalho, verifica-se que alunos sem incentivo de pais exibem as piores médias em todas as habilidades socioemocionais e as maiores discrepâncias em relação ao grupo favorecido no mesmo quesito. Por outro lado, quando verificados os efeitos significativos da religiosidade, percebe-se que, dos subgrupos vulneráveis, é o que apresenta a menor quantidade de atributos afetados, além de ser o único entre todos os subgrupos que não exibe crescimento na abertura a experiências. Uma hipótese para esse resultado seria a de que este subgrupo pode carecer de alguma competência (ou algumas) mais básica, que está no "início" do processo de acumulação de habilidades, o que dificulta ou atrasa o desenvolvimento de outras mais complexas. 
Por fim, procurando verificar por meio de mais uma forma se o efeito do contexto escolar da religiosidade é maior de acordo com o aumento das vulnerabilidades do aluno, apresenta-se um gráfico com os resultados encontrados para a variável que une as três dimensões de vulnerabilidade examinadas (dummy que assume valor 1 para o caso do aluno reunir todas as vulnerabilidades e 0 no caso dessa situação não acontecer).

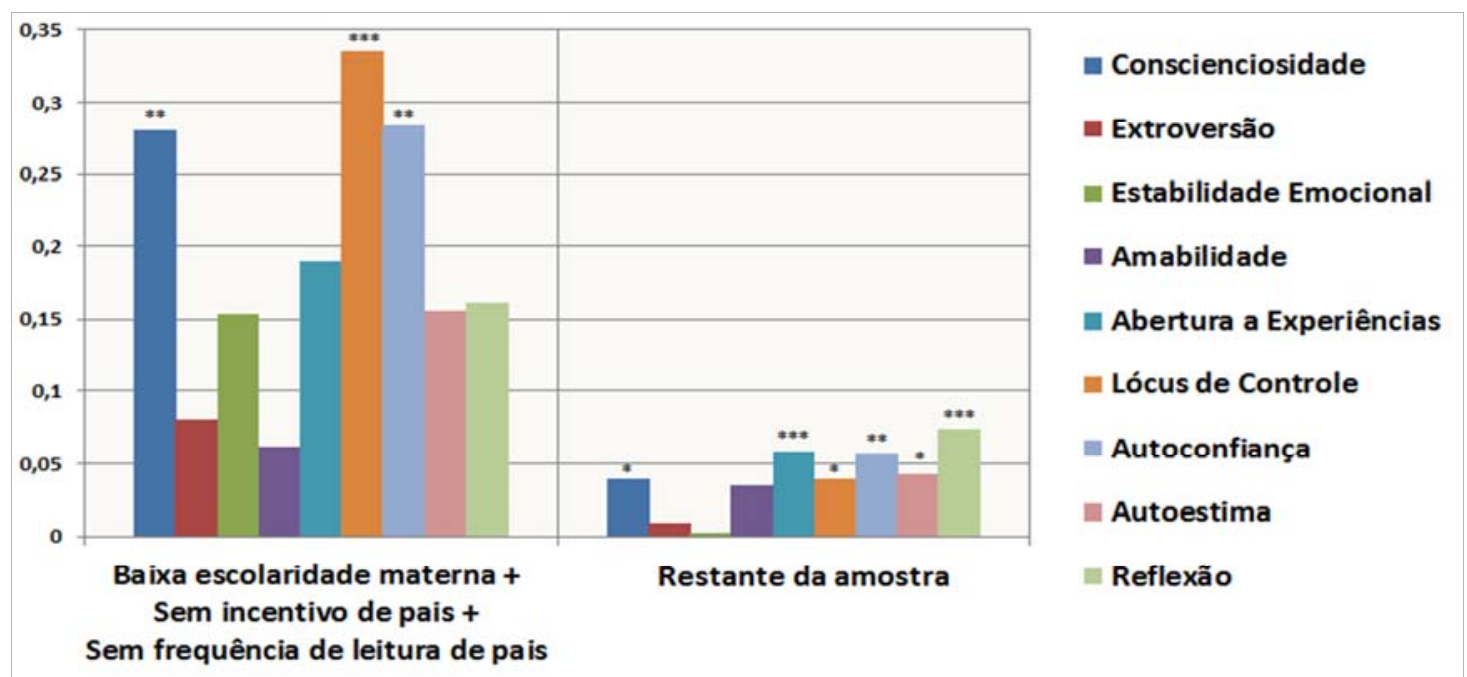

Gráfico 10. Comparativo dos efeitos da religiosidade na escola sobre os alunos mais vulneráveis entre os vulneráveis e dos pertencentes ao restante da amostra.

Fonte: Elaboração própria com uso de dados do Censo Escolar, Prova Brasil e microdados da pesquisa de campo realizada na rede estadual do Rio de Janeiro.

Nota: ***Significante a $1 \%$; ** Significante a $5 \%$; Significante a $10 \%$.

Neste caso, o realce pode ser dado ao aumento na magnitude dos efeitos de praticamente todas as habilidades socioemocionais quando comparados aos dos demais subgrupos analisados. Como já comentado, foram encontrados poucos alunos (se comparados com o total da amostra) com esse perfil (que reúne as três vulnerabilidades), o que contribui para a perda de significância estatística em alguns resultados. Porém, o expressivo aumento dos coeficientes é algo interessante de ser analisado, o que motivou a apresentar o gráfico acima com todos os efeitos (também os não significativos). Os resultados encontrados indicam que quanto mais vulnerável o aluno, maior se apresenta o efeito do contexto escolar da religiosidade sobre suas habilidades, de forma mais acentuada no que se refere à conscienciosidade, lócus de controle e autoconfiança. Nesses três casos e em outros, verificase que os coeficientes superam os maiores apresentados em outros subgrupos (por exemplo, o maior coeficiente do efeito sobre o lócus de controle havia sido constatado para os alunos sem 
incentivo de pais, equivalente a 0,14 , porém, quando o aluno é também vulnerável em termos de escolaridade materna e frequência de leitura de pais, o coeficiente passa a ser 0,34 ).

A seguir, procede-se à conclusão deste primeiro estudo.

\subsection{Conclusão}

Este trabalho investigou os efeitos do contexto escolar da religiosidade sobre as habilidades socioemocionais de adolescentes da rede pública do Rio de Janeiro, procurando analisar, sobretudo, os efeitos de acordo com diferentes dimensões de vulnerabilidade dos alunos. Em relação à amostra total de estudantes, os resultados mostram que a religiosidade na escola contribui para o aumento da abertura a experiências, lócus de controle, autoconfiança, autoestima e reflexão. Com menores magnitudes e significâncias, verificaramse incrementos, também, na conscienciosidade e na amabilidade.

Os achados sugerem que a religiosidade no âmbito educacional contribui, de forma mais expressiva, para o desenvolvimento socioemocional dos alunos com baixo nível de educação da mãe, de forma que esses se equiparam relativamente aos favorecidos nesse quesito, diminuindo a disparidade em termos socioemocionais. Também é reduzida a desigualdade quando a vulnerabilidade do aluno é relacionada a outras questões (ambiente de leitura ou incentivo de pais ao estudo), porém de forma menos acentuada. Considerando que a educação materna é um indicador que reflete o status socioeconômico do aluno (principalmente no Brasil), podem-se fazer alguns apontamentos sobre implicações destes resultados em termos de desigualdades sociais.

Apesar de já haver sido verificado que habilidades não cognitivas contribuem para a obtenção de melhores resultados educacionais, comportamentais e, inclusive, financeiros (HECKMAN, STIXRUD, URZUA, 2006, BORGHANS et al. 2008), ainda é escasso o conhecimento sobre que competências impactam em quais resultados ao longo da vida de uma pessoa e, mais especificamente, sobre indivíduos menos favorecidos. Há pesquisas que apontam para alguns caminhos visando buscar a superação das desigualdades sociais. A partir dos resultados do PISA, por exemplo, sugere-se que é necessário promover em estudantes de ambientes socioeconômicos desfavorecidos a "autoconfiança e motivação, de forma que possam explorar seu potencial" (OCDE, 2011a, pág. 4). Essa recomendação foi elaborada a partir da análise do perfil dos alunos considerados como "resilientes" (provenientes de meios desfavoráveis, mas que alcançam altos desempenhos do ponto de vista dos padrões internacionais, quando se leva em consideração seu ambiente). Cabe sinalizar que a principal 
relação com a resiliência ocorre com a autoconfiança, sendo menor a que se refere à motivação, além de que esta última se caracteriza por uma origem pessoal (motivação intrínseca) e não ocasionada por estímulos externos (OCDE, 2011a). Interessante notar que tal constatação remete às características do lócus de controle interno (NG et al, 2006), atributo que, na presença da religiosidade na escola, cresce tanto para meninos como para meninas do subgrupo menos favorecido em termos socioeconômicos deste trabalho. Por outro lado, no que diz respeito aos meios de se promover a situação relacionada aos rendimentos financeiros futuros do indivíduo, podem ser citadas pesquisas que consideram efeitos positivos especificamente por parte da autoestima (DRAGO, 2008; BENABOU, TIROLE, 2002) que, no presente estudo, apresenta aumento para as meninas mais pobres quando têm contato com práticas religiosas em sua escola (convém recordar que este é o subgrupo mais vulnerável em termos de expectativa de rendimentos financeiros no futuro, conforme o que a literatura sobre o "gender wage gap" afirma).

Cabe ressaltar, ainda, que entre os estudantes de menor nível socioeconômico, a desigualdade entre gêneros é mais marcante (OCDE, 2011b). Como ressaltado em informes internacionais, há uma preocupação especial em relação aos meninos, cujo desempenho educacional inferior é, em grande parte, atribuído a aspectos comportamentais (como ocuparse menos com deveres de casa, gastar mais tempo jogando videogames e menos com leitura, em particular de textos complexos) (OCDE, 2015d). Essa atitude preocupa não somente em relação à questão acadêmica, mas também reflete uma postura em relação ao aprendizado que pode comprometer o futuro desempenho profissional. A proatividade, independência e autorregulação para adquirir novos conhecimentos e resolver os problemas são características exigidas em um mercado a cada dia mais competitivo. Neste sentido, autores destacam a importância de desenvolver habilidades que englobam a reflexão, como um dos recursos necessários para obter um melhor posicionamento profissional no longo prazo (ERTMER, NEWBY, 1996; FASTRÉ, 2013; PATERSON, CHAPMAN, 2013).

Além disso, os resultados mostram variações nas competências afetadas de acordo com a circunstância do aluno, permanecendo, entretanto, em comum, um aumento nos índices de conscienciosidade quando são alunos desfavorecidos e, entre esses, especialmente os meninos com baixa escolaridade materna (perfil que manifesta o maior aumento nessa habilidade, quando comparado aos outros subgrupos avaliados). Cabe considerar que o aumento da conscienciosidade para esses alunos pode representar um estímulo para a diminuição de índices de violência e criminalidade, uma vez que, segundo dados empíricos, esse atributo socioemocional (juntamente com a amabilidade) exerce um papel de mediação 
nos efeitos da religiosidade sobre a redução de comportamentos agressivos juvenis (SHEPPERD et al, 2015).

Outro ponto a se destacar é o de que, independente do subgrupo analisado (mais ou menos vulnerável ou de acordo com o sexo), sempre foram observados aumentos significativos da religiosidade sobre alguma habilidade conativa (referente à "vontade"). Tais competências estão relacionadas ao esforço consciente proativo para executar ações e comportamentos, sendo que uma parte delas diz respeito a convicções e orientações da pessoa em relação a si mesma, como seria o caso da autoconfiança, autoestima e lócus de controle (SANTOS, 2014; MCGREW, 2007), abordadas neste trabalho. Este tem sido um tipo de habilidade citado como necessário para melhorar o desempenho educacional de adolescentes, especialmente dos menos favorecidos (OECD, 2011a), além de também estar relacionado aos rendimentos financeiros no futuro.

Verificam-se, também, aumentos nos índices de reflexão em todos os subgrupos (com exceção somente dos que não possuem incentivos de pais, cujos efeitos apresentam coeficientes positivos porém não significativos). Na sociedade atual, é crescente a falta do hábito de reflexão, devido, entre outros fatores, a uma maior dispersão com meios digitais e uma preponderância do "mundo das imagens" em detrimento do "mundo dos escritos". A busca por sensações intensas, imediatas e rápidas leva a detrimentos no hábito de parar e pensar. Portanto, pode-se considerar uma geração provavelmente mais vulnerável em termos de reflexão (portanto, toda a amostra pesquisada que, neste caso, também estaria sendo beneficiada por algum mecanismo de substitutibilidade deste contexto escolar).

Em termos mais genéricos, os resultados deste trabalho refletem o que autores afirmam sobre a religiosidade, que se trata de um construto multidimensional que envolve aspectos variados, como crenças, participação, comprometimento e relacionamentos (KING, BOYATZIS, 2015).Verifica-se, a partir do presente estudo, que o contexto escolar da religiosidade oferece efeitos multidimensionais, não atuando somente sobre algumas questões específicas do desenvolvimento humano e sim abrangendo um leque diversificado de fatores comportamentais e atitudinais. Enquanto algumas práticas educacionais exibem um escopo mais direcionado e pontual de consequências, ela se peculiariza, por um lado, pela variedade de tipos de efeitos e, por outro, por uma variação desses últimos de acordo com o público em questão. Mais concretamente, age de forma diferente sobre pessoas de perfis e circunstâncias diferentes. Os resultados deste estudo indicam que a quantidade e magnitude dos efeitos são maiores quando o público é menos favorecido em termos de baixa escolaridade materna e sugerem que esse contexto escolar traz benefícios no que se refere a vulnerabilidades 
peculiares do subgrupo de indivíduos. Um possível mecanismo para isso pode estar relacionado ao fato da religiosidade contribuir para o aumento do bem estar e da felicidade (figura 1), o que traz consequências positivas em diversos aspectos na vida do indivíduo. Pesquisas mostram que pessoas com mães de baixa escolaridade e vulnerabilidade socioeconômica apresentam mais problemas de bem estar, com maior incidência de depressão, retraimento social e outras dificuldades relacionadas (GARNER et al., 2014, EVANS et al., 2005). Em troca, verifica-se que a religiosidade exerce efeitos robustos sobre a depressão juvenil, especialmente para os casos mais sérios (COOLEY FRUEHWIRTH et al, 2016), além de contribuir para outros aspectos de bem estar geral e subjetivo (YONKER et al., 2012, REGNERUS, 2003).

Por fim, ao analisar os mecanismos propostos na figura 2 procurando entender seus processos de influências em termos socioemocionais, considera-se que os recursos provavelmente mais fortes e peculiares da religiosidade (pois outros aspectos podem ser replicados em outras instâncias, como capital cultural e contexto social, por exemplo) estejam relacionados a:

a) Experiências espirituais: há uma tradicional música americana (Amazing Grace) que descreve algumas consequências percebidas pela pessoa em relação à graça divina, que, por sua vez, seria o principal fator causador de experiências espirituais positivas. Trata-se de um dos eixos das religiões cristãs, uma vez que a ele se atribui o destino da vida após a morte, além de que, já nesta vida seria o que determina uma maior proximidade com o ser superior chamado Deus pelos cristãos. Em resumo, acredita-se que, pela graça, Deus mora na alma do cristão, o que traz profundas consequências para ele. Essa é uma das principais questões que impulsionam a abrir mão de determinados comportamentos considerados ilícitos segundo a dimensão da ordem moral (figura 2) (como seria o caso da criminalidade ou violência familiar) porque, por um lado, em alguns casos essas ações podem ser consideradas causadoras de perda da vida eterna e, por outro, porque por esse canal se experimenta um aumento de felicidade, o que fortalece nas dificuldades de modo a não deixar-se levar por influências nocivas de pares (como na criminalidade) ou por estados de ânimo (como no suicídio). Neste sentido, pode-se encontrar, no relato autobiográfico do escritor inglês Chesterton, um exemplo de experiência pessoal em termos de sentimentos de depressão e alegria antes e após o início de uma vida com religiosidade (AYLLÓN, 2013, CHESTERTON, 2012). 
b) Contexto ideológico: um fato histórico que revela a força desse aspecto na vida do ser humano é relatado por Viktor Frankl, especificamente sobre o "sentido de missão" que uma pessoa pode ou não ter e como isso a afeta. O psicólogo descreve sua experiência nos campos de concentração de Auschwitz e Dachau, onde percebeu que os prisioneiros que se orientavam na direção de um futuro que de alguma forma esperava por eles, encontravam assim um sentido para suas vidas, sendo os que apresentavam maiores probabilidades de sobrevivência (FRANKL, 2013). Os ideais, propósitos e significado de vida podem ser concebidos fora do âmbito da religiosidade, porém sua peculiaridade neste campo se dá na medida em que estende a repercussão destes para além do tempo da própria vida, encontrando um significado também para a morte. Llano Cifuentes (2001, pág 284) considera que o homem, ao mesmo tempo em que busca conhecer aspectos sobre o universo, sente também "uma paixão sem medida para descobrir algo que lhe fale (...) de algo que o afeta intimamente: o roteiro da sua "órbita", que lhe indica o sentido da sua vida e da sua morte" e que a fé sairia ao encontro destes anseios dando-lhes respostas.

c) Contexto transcendente: provavelmente o aspecto que se traduz em maiores efeitos em recursos socioemocionais neste contexto se refere à consideração da filiação divina, questão responsável por elementos de compensação em relações psicoafetivas, autoestima e outras variáveis impactadas por carências no âmbito familiar. Neste caso, cabe citar a experiência relatada por André Frossard no livro onde expõe sua vida antes e depois do contato com a religião (FROSSARD, 2010). O jornalista francês ressalta que a questão que mais o impactou foi a descoberta não de uma ideia, mistério ou filosofia, mas sim de uma pessoa. A descrição de como isso o ajudou a encontrar um significado para sua vida e querer melhorar enquanto indivíduo sugere um mecanismo semelhante ao que ocorre entre um filho e um pai, quando o primeiro sente-se amado pelo segundo e, a partir disso, procura retribuir mediante uma diferente postura de vida.

Entre as limitações deste estudo, pode-se citar o fato de se tratar de uma pesquisa transversal. Como se sabe, estudos longitudinais permitem de forma mais precisa a aferição de causalidade. Além disso, seria interessante se houvesse dados dos alunos relacionados a medidas de bem estar e felicidade, permitindo avaliar melhor o mecanismo pelo qual a 
religiosidade pode estar atuando sobre esse aspecto no indivíduo. Por exemplo, o quanto desse efeito é direto e o quanto é mediado pelo lócus de controle, o qual tem se mostrado como um preditor de bem estar geral (NG et al., 2006) e que também mostrou estar relacionado com a religiosidade.

Em continuação, dá-se sequência ao segundo estudo realizado neste trabalho. 


\section{SEGUNDO ESTUDO: MEDIAÇÃO DAS HABILIDADES SOCIOEMOCIONAIS NOS EFEITOS DO CONTEXTO ESCOLAR DA RELIGIOSIDADE SOBRE O DESEMPENHO ACADÊMICO}

\subsection{Introdução}

Apesar da crescente convicção de que a educação precisa abranger não somente o aprendizado acadêmico, mas também o desenvolvimento não cognitivo, é escasso o conhecimento sobre os fatores que promovem tais habilidades e seus mecanismos de funcionamento. Este estudo investiga o papel de mediação das competências socioemocionais nos efeitos gerados pelo contexto escolar da religiosidade sobre as notas de português e matemática. Foram encontrados efeitos mediadores pelos canais da conscienciosidade, abertura a experiências e lócus de controle.

\subsection{Revisão bibliográfica}

A seguir expõem-se, brevemente, questões sobre as diferenças entre o processo de formação de habilidades cognitivas e socioemocionais, os efeitos das habilidades socioemocionais sobre o desempenho acadêmico e a influência da religiosidade sobre este último.

\subsubsection{Diferenças entre os processos de formação de habilidades cognitivas e socioemocionais}

Borghans et al. (2008) expõem que o desenvolvimento dos atributos cognitivos e não cognitivos ocorre ao longo de toda a vida, porém em diferentes graus e estágios no ciclo de vida. Por exemplo, a velocidade do processamento cognitivo tende a subir acentuadamente durante a infância, atingindo o pico no fim da adolescência e depois declina lentamente. Em contraste, alguns traços de personalidade, como a conscienciosidade, aumentam monotonicamente da infância para a idade adulta tardia. Além disso, os autores destacam evidências de que as habilidades socioemocionais são mais maleáveis do que as cognitivas, além de mais sensíveis às influências dos pais e de ambiente em idades mais avançadas. 
Essa diferença na cronologia do desempenho cognitivo e socioemocional é explicada por questões da neurociência. As características não cognitivas, como motivação, autodisciplina e gestão do tempo, por exemplo, estão associadas à evolução do Córtex Pré-frontal (responsável pelas emoções e auto regulação), sendo mais passíveis de mudança com o passar do tempo, uma vez que essa região do cérebro possui uma maleabilidade até, aproximadamente, a idade de 20 anos, como sinalizam Cunha et al. (2006). Por outro lado, esses autores destacam que os escores relacionados ao QI atingem uma certa estabilidade por volta dos 10 anos, sendo mais difíceis de alterar após isso, o que indica que as intervenções direcionadas para a promoção de habilidades cognitivas devem ser realizadas em idades mais precoces, enquanto as voltadas para o desenvolvimento socioemocional obtêm êxito ainda em períodos posteriores. Cabe acrescentar que ocorre, ainda, um efeito inverso: a falta de estímulos recebidos do ambiente, sejam familiares, escolares ou outros, pode prejudicar o desenvolvimento cerebral da criança, resultando em uma atrofia de um sistema que engloba questões variadas e importantes para o desempenho da pessoa na idade adulta, como percepção, interpretação, tomada de decisão, entre outros (HECKMAN, 2008).

Assim sendo, percebe-se que, para um melhor desempenho educacional, sobretudo de crianças e adolescentes de meios vulneráveis, é insuficiente um estímulo unicamente voltado para a cognição, sendo necessária a promoção de outros tipos de habilidades, comportamentais e atitudinais, principalmente quando se considera a maior maleabilidade destas ao longo do tempo.

\subsubsection{Os efeitos das habilidades socioemocionais sobre o desempenho acadêmico}

As habilidades não cognitivas influenciam de diferentes maneiras o desempenho acadêmico. Verificam-se efeitos diretos em medidas como notas, escolaridade final atingida, tempo de conclusão de etapa de estudo, ingresso no ensino superior e assim por diante. Há, também, efeitos indiretos, entre os quais poderiam ser citados o tempo dedicado ao dever de casa, o menor absenteísmo nas aulas e a motivação para aprender. $\mathrm{O}$ atributo mais associado ao rendimento escolar satisfatório, seja por influências diretas ou indiretas, tem sido a conscienciosidade (em alguns casos, supera inclusive o impacto proporcionado pela inteligência). Logo em seguida, aponta-se para a abertura a experiências e o lócus de controle interno, bem como habilidades relacionadas ao autoconceito de modo geral. Os resultados são menos expressivos em relação à 
amabilidade, estabilidade emocional e extroversão, havendo, porém pesquisas que mostram alguns efeitos positivos (e, inclusive, negativos em alguns casos). Visando resumir os principais achados listados em meta-análises e artigos neste campo, expõem-se, no quadro 3, alguns dados empíricos sobre efeitos de atributos socioemocionais sobre o desempenho acadêmico e algumas questões relacionadas ao aprendizado. Além disso, apresentam-se alguns exemplos, também empiricamente comprovados, de como esses efeitos podem estar relacionados a questões de neurociência. 
Quadro 3. Dados empíricos sobre efeitos de habilidades socioemocionais sobre o desempenho acadêmico, atitudes relacionadas ao aprendizado e questões referentes à neurociência

\begin{tabular}{|c|c|c|}
\hline $\begin{array}{c}\text { Habilidade } \\
\text { Socioemocional }\end{array}$ & $\begin{array}{c}\text { Efeitos sobre o } \\
\text { desempenho acadêmico }\end{array}$ & $\begin{array}{c}\text { Efeitos sobre questões } \\
\text { relacionadas ao aprendizado }\end{array}$ \\
\hline $\begin{array}{c}\text { Abertura a } \\
\text { Experiências }\end{array}$ & $\begin{array}{l}\text { - Escolaridade final atingida. } \\
\text { - } 2^{\circ} \text { atributo mais associado às notas. } \\
\text { - Aumento de } 1 \text { desvio-padrão no } \\
\text { construto está associado a acréscimo de } \\
\text { até } 0,2 \text { ano de estudo. }\end{array}$ & $\begin{array}{l}\text { - Motivação para aprender } \\
\text { - Raciocínio crítico } \\
\text { - Abordagem à aprendizagem } \\
\text { - Menor absenteísmo nas aulas }\end{array}$ \\
\hline Amabilidade & $\begin{array}{l}\text { - Correlação positiva com notas no ensino } \\
\text { fundamental (a qual, porém, desaparece } \\
\text { com o avançar do ciclo educacional). }\end{array}$ & $\begin{array}{l}\text { - Comprometimento com } \\
\text { instruções de professores, esforço } \\
\text { e permanecer focado nas tarefas } \\
\text { de aprendizagem. }\end{array}$ \\
\hline Conscienciosidade & $\begin{array}{l}\text { - Escolaridade final atingida. } \\
\text { - Atributo mais associado às notas. } \\
\text { - Comportamentos como pontualidade nas } \\
\text { aulas e entrega do dever de casa preveem } \\
\text { com antecedência de até } 10 \text { anos a } \\
\text { escolaridade final. } \\
\text { - Parcela da variância das notas obtidas } \\
\text { (alunos da } 8^{\text {a }} \text { série) explicada pela } \\
\text { autodisciplina é mais de } 2 \text { vezes maior do } \\
\text { que a explicada pela inteligência. }\end{array}$ & $\begin{array}{l}\text { - Dever de casa: concentração e } \\
\text { comprometimento. } \\
\text { - Esforço sustentado e definição } \\
\text { de metas. } \\
\text { - Gestão do tempo e regulação de } \\
\text { esforço. }\end{array}$ \\
\hline $\begin{array}{l}\text { Estabilidade } \\
\text { Emocional }\end{array}$ & $\begin{array}{l}\text { - Escolaridade final atingida. } \\
\text { - A falta de estabilidade emocional } \\
\text { (neuroticismo) está associada a um pior } \\
\text { desempenho acadêmico. }\end{array}$ & \\
\hline Lócus de Controle & $\begin{array}{l}\text { - Correlação com medidas de desempenho } \\
\text { em testes cognitivos. } \\
\text { - Um desvio-padrão a mais está associado } \\
\text { a cerca de } 1,5 \text { ponto percentuais de } \\
\text { aumento nas chances de completar o } \\
\text { ensino médio. }\end{array}$ & \\
\hline
\end{tabular}

Efeitos do desenvolvimento socioemocional relacionados à neurociência:

Exemplos de achados empíricos

\section{Efeitos sobre questões de neurociência associadas ao desempenho cognitivo}

Indivíduos com sentimento de exclusão social

Indivíduos com sentimento de solidão

Pessoas submetidas a situações de stress

Atributos socioemocionais relacionados ao sono
Dificuldades de raciocínio, tomada de decisão, atenção e persistência ao se deparar com problemas complexos.

Redução da atividade no córtex pré-frontal quando expostos a resolução de problemas de matemática (que demandam em geral o uso da função executiva).

Alteração dos fluxos de dopamina e noradrenalina para o córtex préfrontal, afetando a função executiva.

Ajuda a mente a sumarizar as experiências e aprendizados do dia. $\mathrm{Na}$ medida em que desequilíbrios em atributos socioemocionais afetem o sono, o aprendizado pode ser prejudicado.

Fonte: Elaboração própria com base em Trapmann et al.(2007), Poropat (2009) e Santos (2014). 


\subsubsection{Efeitos da religiosidade sobre o desempenho acadêmico}

Estudos mostram que a religiosidade do indivíduo está associada a resultados educacionais favoráveis (REGNERUS, ELDER, 2003 LEHRER, 2005, REGNERUS, 2000; MULLER, ELLISON, 2001), do mesmo modo que foram constatados benefícios acadêmicos por parte de escolas religiosas. Desde os pioneiros estudos de Coleman et al. (1982) e Coleman e Hoffer (1987), autores apontam para efeitos positivos que estudar em tais colégios trazem para resultados como notas em testes e taxas de conclusão do ensino médio. Tais consequências podem ser provenientes de incrementos não somente de habilidades cognitivas, mas também de socioemocionais. A metaanálise realizada por Yonker et al. (2012), com objetivo de examinar as associações entre espiritualidade/religiosidade e resultados psicológicos em adolescentes e jovens se aproximando da idade adulta, mostrou aumentos significativos nos índices de conscienciosidade e abertura a experiências, que são atributos associados a um melhor desempenho acadêmico. Ainda que essas pesquisas não tenham tido como foco a religiosidade enquanto contexto escolar e sim como algo vivido pelo indivíduo, oferecem insumos interessantes para o âmbito educacional, uma vez que alunos, ao entrar em contato com esse contexto escolar, podem optar por incorporá-lo de alguma forma às suas vidas. Porém, faltam estudos com aferições mais aprofundadas sobre os mecanismos causais que estão por trás dessas questões: "religiosidade gera benefícios para o desenvolvimento socioemocional" e "religiosidade melhora o desempenho acadêmico" procurando identificar por meio de que fatores esses efeitos acontecem e, ainda mais especificamente, se essas duas questões estão relacionadas, ou seja, se há mediação de habilidades socioemocionais no impacto exercido pela religiosidade sobre o desempenho acadêmico. Um exemplo de achado em termos nacionais neste sentido são os resultados da pesquisa realizada por Cunha, Rios-Neto e De Oliveira (2014), onde se verificou que a "frequência de reza e orações" exerce efeitos positivos sobre o desempenho educacional. Porém, um segundo passo na evolução deste conhecimento seria saber porque isso acontece, para poder replicar o mecanismo também por meio de outras instâncias e, em suma, saber como aproveitar de forma mais abrangente esse recurso.

\subsection{Análise descritiva}

A seguir, exibem-se comparativos das médias de atributos socioemocionais de acordo com os níveis de desempenho acadêmico dos alunos da amostra deste trabalho.

O gráfico 11 permite visualizar a discrepância existente entre os níveis de recursos não cognitivos de alunos com desempenho abaixo e acima da média da amostra. Enquanto o 
primeiro grupo apresenta médias negativas para todas as habilidades, o inverso ocorre para o segundo, onde elas passam a ser positivas.

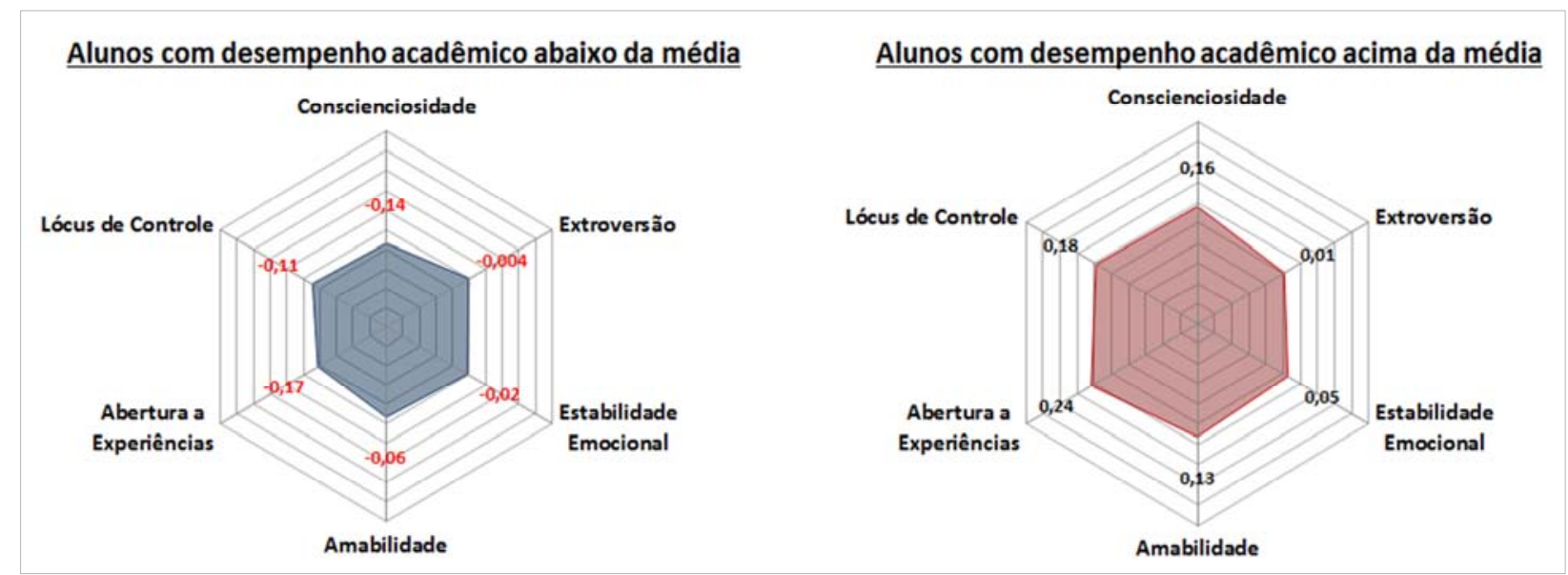

Gráfico 11. Comparativo de médias de habilidades socioemocionais por desempenho acadêmico.

Fonte: Elaboração própria com uso de dados do Saerjinho e microdados da pesquisa de campo realizada na rede estadual do Rio de Janeiro.

Ademais, quando se divide a amostra em quartis de desempenho por ordem crescente, percebe-se mais claramente que atributos não cognitivos acompanham os cognitivos.

No gráfico 12, pode-se notar que praticamente todas as características socioemocionais acompanham o crescimento do desempenho acadêmico, de forma mais marcante a abertura a experiências, seguida pelo lócus de controle e conscienciosidade, principalmente quando se comparam o primeiro e o último quartis.

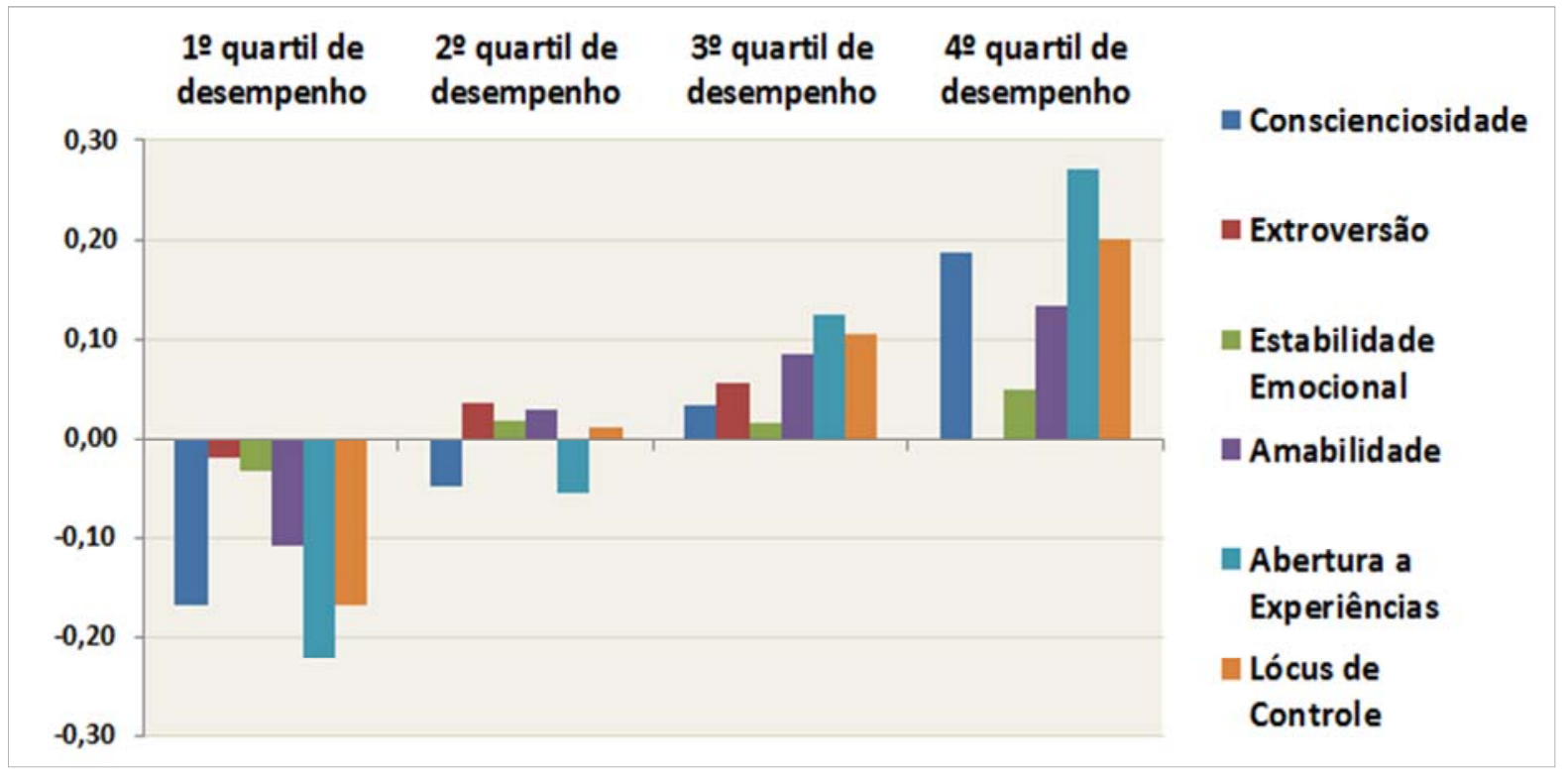

Gráfico 12. Médias de habilidades socioemocionais por desempenho acadêmico crescente

Fonte: Elaboração própria com uso de dados do Saerjinho e microdados da pesquisa de campo realizada na rede estadual do Rio de Janeiro. 
Por outro lado, analisando as correlações entre os recursos não cognitivos e as notas de português e matemática, nota-se uma relação positiva, com exceção de somente um deles (a extroversão sobre o desempenho em matemática).

Tabela 11. Correlação entre socioemocionais e desempenho acadêmico

\begin{tabular}{lcccccc}
\hline $\begin{array}{c}\text { Desempenho } \\
\text { Acadêmico }\end{array}$ & Conscienciosidade & Extroversão & $\begin{array}{c}\text { Estabilidade } \\
\text { Emocional }\end{array}$ & $\begin{array}{c}\text { Lócus de } \\
\text { Controle }\end{array}$ & Amabilidade & $\begin{array}{c}\text { Abertura a } \\
\text { Experiências }\end{array}$ \\
\hline Matemática & $0,126^{* * *}$ & $-0,018^{* *}$ & $0,038^{* * *}$ & $0,026^{* * *}$ & $0,049 * * *$ & $0,081^{* * *}$ \\
Português & $0,142 * * *$ & $0,039 * * *$ & $0,025 * * *$ & $0,177^{* * *}$ & $0,136 * * *$ & $0,191 * * *$ \\
\hline
\end{tabular}

Fonte: Elaboração própria com uso de dados do Saerjinho e microdados da pesquisa de campo realizada na rede estadual do Rio de Janeiro.

Nota: ***Significante a $1 \%$; ** Significante a $5 \% ; *$ Significante a $10 \%$.

Olhando para esses resultados de uma forma genérica, deduz-se que essas duas dimensões, acadêmica e socioemocional, estejam associadas de forma positiva (com exceção da extroversão em relação ao desempenho em matemática).

\subsection{Metodologia}

Este estudo investiga se competências socioemocionais são mediadoras do efeito da religiosidade no contexto escolar sobre o desempenho acadêmico. Neste trabalho, utiliza-se uma análise estatística de mediação que, segundo Hayes e Scharkow (2013), tem princípios ilustrados pelo modelo abaixo.

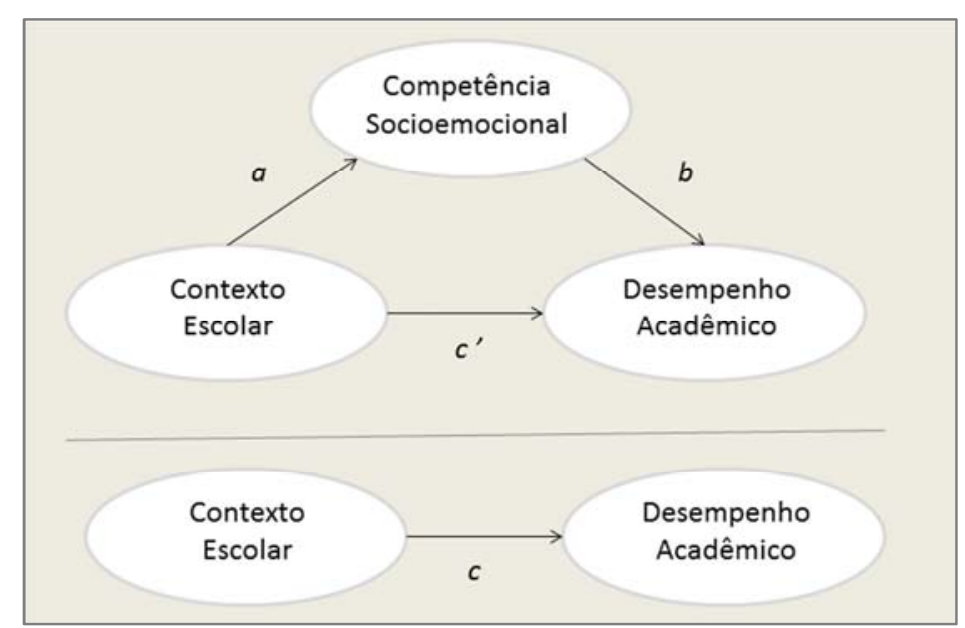

Figura 4. Modelo de mediação simples de habilidades socioemocionais nos efeitos do contexto escolar sobre o desempenho acadêmico

Fonte: Elaboração própria com base em Hayes e Scharkow (2013) 
Pode-se verificar pela Figura 4 que, neste modelo, a variável independente ( $X$ ), contexto escolar, influencia a variável dependente $(Y)$, desempenho acadêmico, diretamente pelo caminho representado por $c^{\prime}$, que denominamos de efeito direto, e indiretamente, pelo caminho representado por $a b$, que denominamos de efeito indireto, através do mediador $(\mathrm{M})$, que neste estudo, supomos serem as competências socioemocionais. Adicionando os efeitos diretos e indiretos, obtém-se o efeito total, $c\left(c=c^{\prime}+a b\right)$, ou seja, o efeito do contexto escolar sobre o desempenho acadêmico. Em relação ao contexto escolar analisado neste trabalho, os efeitos diretos e indiretos poderiam ser explicados da seguinte forma:

Efeito direto (representado por $c^{\prime}$ no modelo da figura 4): pode ocorrer, por exemplo, quando um aluno decide permanecer na escola ou se dedicar mais ao estudo a partir de um ensinamento recebido de que é melhor optar por uma vida honesta do que ingressar no crime. Cabe destacar que, neste trabalho, o efeito direto calculado pode englobar não somente o efeito direto propriamente dito, como também resíduos de efeitos indiretos não mensurados (como seria o caso, por exemplo, de efeitos sobre habilidades cognitivas).

Efeito indireto (o produto de $a b$ na figura 4): um exemplo poderia remeter ao aumento da esperança no indivíduo, ao sentir-se amparado e acompanhado por um ser maior (suscitando incrementos no lócus de controle e autoconfiança), o que pode estimular a motivação intrínseca ao estudo, por acreditar mais nas chances de sucesso desse esforço.

A estratégia de estimação dos caminhos rotulados como $a, b, c$ e $c^{\prime}$ faz uso de um modelo de equações estruturais simultâneas, o qual possui a vantagem de estimar os efeitos indiretos e totais, além de poder incorporar no modelo de mediação simples um modelo maior e até mesmo usar variáveis latentes ${ }^{2}$ para medir qualquer parte do modelo de mediação ${ }^{3}$. Para isto, utiliza-se o comando SEM (Structural equation model estimation command) do software Stata, juntamente com a opção "estat teffects" que proporciona os efeitos indiretos, diretos e totais. Portanto, $a, b, c$ e $c^{\prime}$ podem ser estimados como o modelo representado pelas equações:

$$
\begin{aligned}
& \boldsymbol{M}=\boldsymbol{i}_{\mathbf{1}}+\boldsymbol{a}_{0}^{\prime} \boldsymbol{X}+\boldsymbol{a}_{\mathbf{1}} \text { Rel }+\boldsymbol{e}_{\mathbf{1}} \\
& Y=i_{2}+\boldsymbol{c}^{\prime}{ }_{0} \boldsymbol{X}+c_{1} R e l+\boldsymbol{b}^{\prime} \boldsymbol{M}+e_{2}
\end{aligned}
$$

Onde $\boldsymbol{M}=\left[\begin{array}{lll}\boldsymbol{M}_{1} & \ldots & \boldsymbol{M}_{6}\end{array}\right]$ equivale ao conjunto das seis habilidades socioemocionais medidas pelo Senna $1, Y$ ao desempenho acadêmico, Rel à Religiosidade, $X$ às variáveis de controle, $c_{1}$ ao efeito direto, ao passo que o efeito indireto corresponde ao produto de cada coordenada do

\footnotetext{
${ }^{2}$ Variável latente é um construto teórico, ou seja, é uma variável não observada que pode ser construída a partir de duas ou mais variáveis observadas.

${ }^{3}$ Ver StataCorp (2015).
} 
vetor $a_{1}$ com cada coordenada do vetor $b$ ', além de que $i_{1}$ e $i_{2}$ são os interceptos da regressão e $e_{1}$ e $e_{2}$ são os resíduos.

Este modelo será replicado duas vezes para cada competência socioemocional $(M)$, que supomos ser o mediador do efeito do contexto escolar da religiosidade sobre o desempenho acadêmico, uma para $Y$, desempenho acadêmico, por meio da variável notas em testes de português e outra, para $Y$ por meio da variável notas em testes de matemática. O vetor de covariadas $X_{1}, \ldots, X_{k}$, que selecionamos para nosso modelo conta com características individuais (sexo, idade, raça), do ambiente familiar (se o pai e a mãe sabem ler e a quantidade de livros na residência) e escolares (proporção de professores com nível superior, localização da escola em zona urbana ou rural, se possui biblioteca e se há religiosidade).

\subsection{Resultados}

Usando um modelo de equações estruturais simultâneas e incluindo variáveis sobre características individuais, do ambiente familiar e escolar, da religiosidade no contexto escolar, competências socioemocionais e desempenho acadêmico, pretende-se verificar se o efeito indireto (ou seja, efeitos do contexto escolar da religiosidade sobre o desempenho acadêmico que são mediados por competências socioemocionais), é significante e quanto o efeito indireto é responsável pelo efeito total (efeitos da religiosidade sobre o desempenho acadêmico).

A seguir, apresenta-se a tabela 12, onde são expostos os efeitos que o contexto escolar da religiosidade exerce sobre as notas de português e matemática.

O primeiro ponto a ser comentado é que o resultado obtido foi robusto tanto no modelo onde o desempenho escolar é representado por notas em português quanto por notas em matemática. 
Tabela 12. Análise de mediação das habilidades socioemocionais nos efeitos do contexto escolar da religiosidade sobre o desempenho acadêmico

\begin{tabular}{lcc}
\hline & Português & Matemática \\
\cline { 2 - 3 } Efeito Total & $0,256^{* * *}$ & $0,120^{* * *}$ \\
Efeito Indireto Total & $0,106^{* * *}$ & $0,057^{* * *}$ \\
Efeito Indireto - Conscienciosidade & $0,005^{*}$ & $0,004^{*}$ \\
Efeito Indireto - Extroversão & 0,000 & 0,000 \\
Efeito Indireto - Estabilidade Emocional & $-0,001$ & 0,000 \\
Efeito Indireto - Amabilidade & 0,003 & 0,002 \\
Efeito Indireto - Abertura a Experiências & $0,012^{* * *}$ & $0,005^{* \star *}$ \\
Efeito Indireto - Lócus de Controle & $0,009^{* *}$ & $0,004^{* *}$ \\
Efeito Direto & $0,150^{* * *}$ & $0,062^{* * *}$ \\
Proporção do Efeito Total Mediado & $41 \%$ & $48 \%$ \\
\hline
\end{tabular}

Fonte: Elaboração própria com uso de dados do Censo Escolar, Prova Brasil, Saerjinho e microdados da pesquisa de campo realizada na rede estadual do Rio de Janeiro.

Nota: ***Significante a $1 \%$; ** Significante a $5 \%$; * Significante a $10 \%$.

Como se pode verificar, há habilidades socioemocionais que se mostram mediadoras dos efeitos do contexto escolar da religiosidade sobre o desempenho acadêmico, concretamente: a conscienciosidade, a abertura a experiências e o lócus de controle. Cabe observar que, no caso da conscienciosidade, o efeito é significante a um nível de $10 \%$. Os resultados mostram que a religiosidade na escola exerce efeitos totais positivos e significativos sobre as duas notas, porém o efeito sobre a nota em português $(0,26)$ supera o exercido sobre a matemática $(0,12)$. Por outro lado, verifica-se um maior percentual de mediação das habilidades socioemocionais no caso da matemática (48\%) do que em português $(41 \%)$.

A figura 5 exibe, de forma gráfica, os resultados em termos de efeitos significativos em relação aos efeitos diretos e indiretos mensurados. 


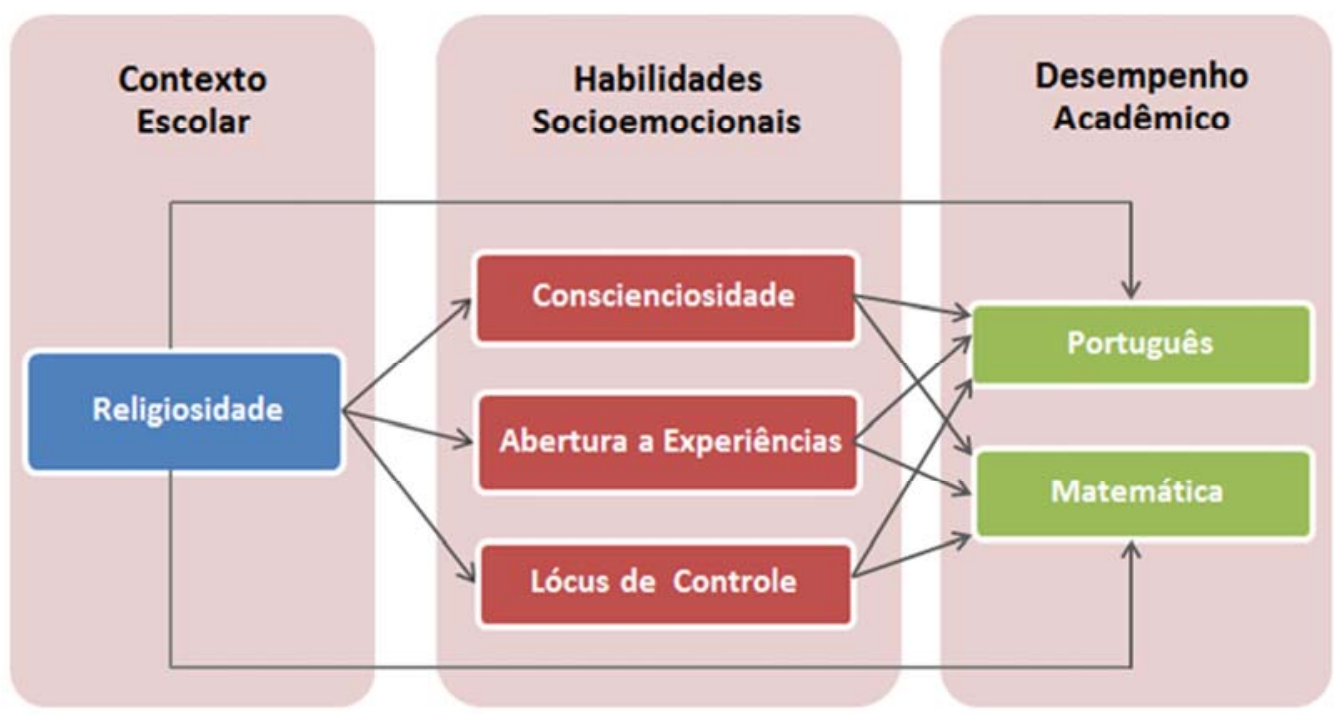

Figura 5. Mediação de habilidades socioemocionais nos efeitos do contexto escolar da religiosidade sobre o desempenho acadêmico

Fonte: Elaboração própria com uso de dados do Censo Escolar, Prova Brasil, Saerjinho e microdados da pesquisa de campo realizada na rede estadual do Rio de Janeiro.

Mediante o cruzamento dos resultados com os achados da literatura, podem ser feitas algumas análises, descritas adiante.

Inicialmente, poderia ser mencionada a presença da conscienciosidade exercendo um papel de mediação na figura 5, o que reforça os resultados empíricos apresentados pela literatura, uma vez que se trata do atributo socioemocional mais relacionado às notas, escolaridade final atingida e comportamentos que favorecem o bom rendimento educacional, tais como esforço acadêmico, entre outros.

A respeito da abertura a experiências e do lócus de controle, que se mostraram como mediadores nos efeitos deste contexto escolar sobre as notas, já era de se esperar esse resultado, uma vez que, ao mesmo tempo em que exibiram crescimento na presença de práticas religiosas na escola (primeiro estudo deste trabalho), são também indicados por pesquisas como associados positivamente a medidas de desempenho cognitivo e à escolaridade final atingida. Neste caso, é provável que o efeito indireto da religiosidade, pela mediação desses dois canais, esteja atrelado não somente ao um melhor desenvolvimento cognitivo, motivado por esses dois atributos, como também por contribuir para algumas questões comportamentais relacionadas a essas competências que favorecem o aprendizado, mais concretamente a motivação para aprender e o menor absenteísmo nas aulas (que podem estar sendo positivamente influenciados pela religiosidade especialmente pelos mecanismos do contexto ideológico ou de role models). O mecanismo de capital cultural da religiosidade, por sua vez, também pode estar por trás dessa mediação em termos atitudinais, porém talvez 
se destaque por influenciar as relações da abertura a experiências diretamente com atributos cognitivos (por exemplo, uma pessoa com um maior capital cultural pode ter mais elementos que facilitem o aumento da sua criatividade - faceta da abertura a experiências - e com isso, elaborar melhor uma redação, obtendo maiores notas de português).

Concretamente em relação à abertura a novas experiências, segundo Le Pine et al. (2000), indivíduos dotados de curiosidade intelectual normalmente buscam experiências e ideias novas e não convencionais. A religiosidade pode estar estimulando esse fator mediante conhecimentos sobre realidades que fogem do convencional e geram indagações em novas perspectivas. Neste sentido, pode-se citar o conceito proposto por The Fetzer Institute, onde se define a espiritualidade como algo relacionado ao transcendente, abordando questões sobre o significado da vida a partir da proposição de que há mais do que o que se pode ver ou entender totalmente (KING, BOYATZIS, 2015). Oferecer conhecimentos sobre realidades que transcendem as já conhecidas, bem como fomentar a reflexão sobre sua relação com a própria vida, pode proporcionar estímulos à curiosidade intelectual, sendo esse um possível canal para o estímulo ao desenvolvimento cognitivo, uma vez que se trata de um atributo destacado por acadêmicos como associado ao desempenho acadêmico (VON STUMM et al, 2011).

No que se refere especificamente ao lócus de controle, um dos principais mecanismos de influência da religiosidade sobre essa habilidade provavelmente esteja atrelado ao contexto transcendente (que pode transmitir maiores sentimentos de segurança e otimismo em relação à consecução de metas, conforme abordado no primeiro estudo), portanto poderia ser esse o canal do efeito indireto que causa sobre as notas.

Caberia também analisar o efeito direto encontrado sobre as notas, fato que reforça o indicado pela literatura a respeito da existência de efeitos diretos e indiretos da religiosidade sobre o desempenho acadêmico de alunos (REGNERUS, 2003). Estudos mostram que a religiosidade contribui para o aumento do tempo gasto por estudantes em dever de casa e no incremento de suas expectativas acadêmicas (MULLER, ELLISON, 2001, REGNERUS, 2000), em uma maior frequência escolar (FREEMAN, 1986), no aumento da conexão escolar (AZAGBA et al, 2014) e no reforço de valores relacionados à educação (REGNERUS, 2003). Neste aspecto, o contexto ideológico da religiosidade pode estar sendo especialmente responsável para a tomada de decisões "pró-estudo" na vida do adolescente: por exemplo, quando se assume a necessidade de procurar ser um bom estudante e profissional para servir melhor à sociedade, optando por ir à escola em vez de ficar na rua ou seguir o crime. 
Em acréscimo, podem estar ocorrendo efeitos a partir de questões referentes a hábitos de saúde. Estudos mostram que dormir um mínimo necessário de horas ajuda a prestar atenção nas aulas e favorece o desempenho acadêmico (WANG; SABIA; CESUR, 2016). Por outro lado, autores mostram que a religiosidade exerce uma influência positiva sobre comportamentos saudáveis dos adolescentes, entre eles o hábito de dormir as horas necessárias (WALLACE; FORMAN, 1998).

Ademais, podem existir outros canais indiretos, não avaliados neste trabalho, que também estejam mediando os efeitos da religiosidade e somam-se aos efeitos diretos encontrados. Alguns desses canais são relatados a seguir.

Uma possibilidade pode estar relacionada ao contexto social da religiosidade. Esta foi uma das propostas feitas por Glanville et al. (2008). Os autores investigaram o papel do capital social e da participação em atividades extracurriculares em mediar a relação entre a participação em atividades religiosas e o desempenho acadêmico, evasão escolar do ensino médio e conexão escolar. Eles verificaram que a participação religiosa promove maiores redes de relacionamento intergeracional, redes de amizades com mais recursos educacionais e normas, além de participação extracurricular. Essas variáveis responderam por uma pequena parcela da influência da participação religiosa de adolescentes sobre seus resultados acadêmicos.

Por outro lado, ainda no que diz respeito ao aspecto social proporcionado pela religiosidade, pode-se evocar efeitos que estejam ocorrendo motivados por questões de neurociências, conforme exposto no quadro 3. Concretamente, é apontado que indivíduos com sentimentos de exclusão social apresentam dificuldades de raciocínio, tomada de decisão, atenção e persistência quando se deparam com problemas complexos. Ademais, pessoas com sentimentos de solidão podem ter reduzidas suas atividades no córtex pré-frontal quando expostas a resolução de problemas de matemática (que demandam em geral o uso da função executiva). Uma hipótese para o mecanismo do efeito indireto da religiosidade neste caso, tendo em vista o exposto da literatura, poderia remeter ao contexto social e aos fatores de capital social e network closure, se consideramos que a redução de sentimentos de exclusão social e solidão podem melhorar o desempenho acadêmico de alunos. Cabe lembrar que, no caso da religiosidade enquanto contexto escolar, o contexto social provavelmente não seria o aspecto mais diretamente relacionado aos resultados, porque geralmente não se proporcionam no colégio essas interações (ao passo que os outros dois contextos - ideológico e transcendente - apresentam mais possibilidades de serem desenvolvidos em âmbito escolar). Porém, pode-se supor que pelo contato com práticas religiosas no colégio, a pessoa queira 
participar também de atividades fora da escola e, por esse meio, tenha acesso aos recursos proporcionados pelo contexto social.

Outro canal de efeitos poderia remeter a habilidades cognitivas. Neste sentido, pesquisas multidisciplinares poderiam oferecer mais explicações. Por exemplo, para verificar se há alguma influência da religiosidade sobre aspectos neurológicos que facilitem, de alguma forma, o raciocínio ou outras questões relacionadas ao aprendizado.

O próximo subitem expõe as conclusões do presente estudo.

\subsection{Conclusão}

Este trabalho teve como objetivo investigar se competências socioemocionais são mediadoras dos efeitos do contexto escolar da religiosidade sobre o desempenho acadêmico. Por meio da modelagem de equações estruturais simultâneas e do método de inferência Sobel test, verifica-se que a abertura a experiências, lócus de controle, conscienciosidade exercem papel de mediação nesse processo. Percebe-se, portanto, que a religiosidade na escola exerce efeitos positivos sobre as notas de matemática e português e que uma parcela desse efeito é explicada por atributos socioemocionais.

Estudos mostram que o desempenho acadêmico pode ser influenciado pela promoção do desenvolvimento socioemocional dos alunos (Durlak et al, 2011), porém ainda há poucas pesquisas a respeito de como e porque isso ocorre (que competências impactam em que aspectos cognitivos, assim como os mecanismos pelos quais isso acontece). Sendo mais bem conhecido o processo pelo qual as competências socioemocionais influenciam de forma mediadora o rendimento escolar, pode-se criar ou aprimorar políticas públicas que estimulem tais efeitos, promovendo assim os resultados educacionais dos alunos.

Neste sentido, este estudo propôs distintos mecanismos para cada relação de mediação apresentada, mediante o cruzamento dos resultados com os achados da literatura. Com isso, é oferecido material para futuras pesquisas que visem aprofundar nos mecanismos propostos, por meio de avaliação empírica a respeito do que é sugerido, evoluindo em termos teóricos e práticos neste tema.

Finalizando este trabalho, procede-se às considerações finais da tese. 


\section{CONSIDERAÇÕES FINAIS}

O desenvolvimento socioemocional tem sido apontado como necessário para o bem estar individual e o progresso social, motivo pelo qual é crescente o número de estudos sobre formas de promovê-lo, sobretudo por meio da educação. Esta tese analisou dois aspectos sobre as associações entre o desenvolvimento socioemocional e a religiosidade na escola: os efeitos deste contexto escolar sobre as habilidades não cognitivas, sobretudo para alunos menos favorecidos em termos socioeconômicos e familiares, e o papel de mediação das competências socioemocionais nos efeitos deste contexto sobre o desempenho acadêmico.

Trata-se de uma iniciativa inédita em termos nacionais, se consideramos que, apesar de existirem estudos internacionais sobre os efeitos socioemocionais da religiosidade, o mesmo não se pode afirmar no contexto brasileiro. Além disso, não foram encontrados estudos sobre a influência da religiosidade enquanto contexto escolar sobre o desenvolvimento não cognitivo de alunos em âmbito nacional.

Os principais resultados encontrados sugerem uma contribuição deste contexto escolar para a redução das desigualdades sociais, uma vez que exibe efeitos maiores e mais abrangentes para alunos com baixa escolaridade materna, indicador estreitamente relacionado, especialmente no Brasil, ao status socioeconômico. Neste sentido, algumas considerações podem ser feitas.

Como afirmou Angel Gurría, secretário geral da Organização para a Cooperação e Desenvolvimento Econômico (OCDE, 2015a), "a ausência de uma educação de qualidade é a mais poderosa forma de exclusão social, impedindo as pessoas de se beneficiarem do crescimento econômico e do progresso social. Reproduzindo esse quadro, o Brasil é um país que exibe resultados educacionais preocupantes e que se destaca mundialmente pelo elevado índice de desigualdade, apresentando um coeficiente Gini (indicador que reflete a desigualdade de renda, entre 0 e 1) de 0,55. A média desse coeficiente entre os países membros da OCDE é de 0,32 e o país mais desigual entre eles, o Chile, exibe uma taxa menor do que a brasileira: 0,51 (OECD, 2015b). Um dos caminhos para reverter essa situação está no que Heckman (2008) ressalta: a desigualdade social pode ser reduzida mediante a promoção de habilidades na população mais vulnerável. Segundo Heckman, Stixrud, and Urzua (2006) e Borghans et al. (2008), as competências socioemocionais são fortes preditores de sucesso socioeconômico, sendo tão importantes quanto habilidades relacionadas à cognição para produzir resultados na vida adulta. Mais ainda, atributos socioemocionais 
promovem o desenvolvimento dos cognitivos e podem ser estimulados por intervenções e outros meios junto a famílias desfavorecidas (HECKMAN, 2008).

Neste sentido, este trabalho investigou os efeitos do contexto escolar da religiosidade sobre as habilidades socioemocionais de adolescentes da rede pública do Rio de Janeiro. Em relação à amostra total de estudantes, os resultados mostram que a religiosidade na escola contribui para o aumento da abertura a experiências, lócus de controle, autoconfiança, autoestima e reflexão. Com menores magnitudes e significância, verificaram-se incrementos, também, na conscienciosidade e na amabilidade. Os achados sugerem que a religiosidade no âmbito educacional contribui, de forma mais expressiva, para a redução de desigualdades em termos socioemocionais de alunos com baixo nível de educação da mãe, de forma que esses se equiparam relativamente aos favorecidos nesse quesito. Também é reduzida a desigualdade quando a vulnerabilidade do aluno é relacionada a outras questões (ambiente de leitura ou envolvimento de pais), porém de forma diferente e em um número menor de competências. Permanece, entretanto, em comum, um aumento comum a todos os subgrupos de alunos desfavorecidos: o incremento nos índices de conscienciosidade. Os alunos favorecidos também apresentam benefícios em seu desenvolvimento socioemocional, porém com menores magnitudes e se caracterizando especialmente por um acréscimo na abertura a experiências e reflexão.

Assim sendo, entre as aportações deste trabalho está a consideração de que não verificar a existência de um contexto de religiosidade no âmbito escolar pode levar a um viés nos resultados de pesquisas quando se investigam habilidades não cognitivas e, especialmente quando se comparam grupos de diferentes níveis de escolaridade materna. Como se pôde averiguar, o desenvolvimento socioemocional de adolescentes com mães de baixa educação apresenta maiores benefícios na presença de um contexto escolar com religiosidade. Portanto, analisar conjuntamente alunos de escolas com e sem práticas religiosas pode levar a resultados enviesados pela endogeneidade dessa variável.

Por outro lado, foram identificados efeitos diretos e indiretos da religiosidade na escola sobre as notas de português e matemática dos alunos, sendo que algumas habilidades mostraram-se como responsáveis por uma parcela de mediação nesses efeitos, especificamente a conscienciosidade, a abertura a experiências e o lócus de controle. Esse fato reforça o que vem sendo apontado por inúmeros pesquisadores da atualidade, sobre a importância de se promover o desenvolvimento socioemocional tendo em vista também à melhora dos indicadores educacionais. 
Observa-se que os dados utilizados neste trabalho possuem uma vantagem de redução de viés de seleção de amostra se comparados a outros provenientes de pesquisas no campo de religiosidade fora do âmbito escolar, uma vez que pessoas que buscam uma maior religiosidade podem, por um lado, ser impulsionadas a isso devido a alguns atributos socioemocionais positivos prévios (como amabilidade, por exemplo, que pode contribuir para o indivíduo se identificar pessoalmente com propósitos de ajuda humanitária, etc.) ou também negativos, como seria o caso de pessoas que buscam a religião como forma de resolver problemas em sua vida ou em busca de conforto espiritual, como seria o caso de pessoas com depressão, conforme exposto por Cooley Fruehwirth et. al (2016). No caso de alunos de colégios públicos, a redução desse viés é ainda mais expressiva do que nos casos de escolas particulares, uma vez que tais estudantes possuem menos opções de mobilidade física, sendo o critério de escolha do colégio normalmente algumas questões práticas, como a proximidade da casa ou do trabalho dos pais.

Por fim, considera-se que, da mesma forma que a religiosidade vem sendo indicada como um recurso para políticas públicas em outros âmbitos como, por exemplo, da saúde (COOLEY FRUEHWIRTH et. al, 2016), seu potencial para promover o desenvolvimento socioemocional deve ser levado em consideração em políticas que tenham por objetivo oferecer uma melhor educação, de forma a reduzir as desigualdades sociais. 


\section{REFERÊNCIAS}

ACHENBACH, T. M. Manual for the Child Behavior Checklist / 4-18 and the 1991 profile. University of Vermont, Department of Psychiatry, Burlington, VT, 1991

AGUILÓ, A. Educação single-sex: perguntas e respostas. Editora Quadrante, 2015.

ARTOLA, Teresa. Educación diferenciada. Algunas razones educativas. European Association Single-Sex Education. 2014. Disponível em http://www.easse.es/docs/content/ 320/teresa-artola-estudio.pdf

AYLLÓN, J. R. Nove ateus mudam de ônibus. Editora Quadrante, 2013.

AZAGBA, Sunday; ASBRIDGE, Mark; LANGILLE, Donald B. Is religiosity positively associated with school connectedness: evidence from high school students in Atlantic Canada?. The Journal of Primary Prevention, v. 35, n. 6, p. 417-427, 2014.

BAKER, DP.; STEVENSON, DL. Mothers' strategies for children's school achievement: Managing the transition to high school. Sociology of Education, p. 156-166, 1986.

BENABOU, R., TIROLE, J. Self-confidence and Personal Motivation. Quarterly Journal of Economics 117, 871-915, 2002.

BERTRAND, M. New perspectives on gender. Handbook of labor economics, v. 4, p. 15431590, 2011.

BIANCHI, Suzanne M.; ROBINSON, John P.; MILKE, Melissa A. The changing rhythms of American family life. Russell Sage Foundation, 2006.

BLASCOVICH, J., TOMAKA. Measures of self-esteem. In J. P. Robinson, P. R. Shaver, \& L. S. Wrightsman (Eds.), Measures of personality and social psychological attitudes. New York: Academic, 1991.

BLAU, Francine D.; KAHN, Lawrence M. The Gender Wage Gap: Extent, Trends, and Explanations. Institute for the Study of Labor (IZA), 2016.

BORGHANS, L., DUCKWORTH, A.L., HECKMAN, J.J. TER WEEL, B. The economics and psychology of personality traits. Journal of Human Resources, v. 43, n. 4, p. 972-1059, 2008. 
BRAÑAS-GARZA, Pablo; ESPÍN, Antonio; NEUMAN, Shoshana. Effects of religiosity on social behaviour: Experimental evidence from a representative sample of Spaniards. 2013.

CABRERA, Natasha $J$. et al. Influence of mother, father, and child risk on parenting and children's cognitive and social behaviors. Child Development, v. 82, n. 6, p. 1985-2005, 2011.

CAMERON, K. S.; CAZA, A. Contributions to the discipline of positive organizational scholarship. American Behavioral Scientist, v. 47, p. 731-739, 2004.

CAMPS, J. Inteligencia de género para la escuela, Editorial Círculo Rojo ( $2^{\mathrm{a}}$ edición), 2015.

CASEL - Collaborative for Academic, Social, and Emotional Learning. Safe and sound: An educational leader's guide to evidence-based social and emotional learning programs Illinois edition. Chicago, 2005.

CENSO, I. B. G. E. Disponível em:< http://www. censo2010. ibge. gov. br/>. Consultado em, v. $12,2010$.

CHESTERTON, G. K. Autobiografia. Editora Ecclesiae, 2012.

COLEMAN, James Samuel et al. Public and private high schools: The impact of communities. New York: Basic Books, 1987.

COLEMAN, James Samuel; HOFFER, Thomas; KILGORE, Sally. High school achievement: Public, Catholic, and private schools compared. New York: Basic Books, 1982.

COOLEY FRUEHWIRTH, Jane; IYER, Sriya; ZHANG, Anwen. Religion and Depression in Adolescence. Institute for the Study of Labor (IZA), 2016.

CRIBB, Victoria L.; HAASE, Anne M. Girls feeling good at school: School gender environment, internalization and awareness of socio-cultural attitudes associations with selfesteem in adolescent girls. Journal of Adolescence, v. 46, p. 107-114, 2016.

CROSNOE, Robert; COOPER, Carey E. Economically disadvantaged children's transitions into elementary school linking family processes, school contexts, and educational policy. American Educational Research Journal, v. 47, n. 2, p. 258-291, 2010. 
CUNHA, F., HECKMAN, J. J., LOCHNER, L.; MASTEROV, D. V. Interpreting the evidence on life cycle skill formation. Handbook of the Economics of Education, v. 1, p. 697-812, 2006.

CUNHA, F.; HECKMAN, J. Investing in our Young People, Paper for National Institutes of Health. 2006.

CUNHA, F.; HECKMAN, J.J. The technology of skill formation. National Bureau of Economic Research, 2007.

CUNHA, Nina Menezes; RIOS-NETO, Eduardo Luiz Gonçalves; DE OLIVEIRA, Ana Maria Hermeto Camilo. Religiosidade e desempenho escolar: o caso de jovens brasileiros da região metropolitana de Belo Horizonte. Pesquisa e Planejamento Econômico, v. 44, n. 1, 2014.

DE RAAD , B.; SCHOUWENBURG , H.C. Personality in learning and education: a review. European Journal of Personality, v. 10, p. 303-336, 1996.

DI FABIO, A.; KENNY, M. E. Emotional Intelligence and Perceived Social Support Among Italian High School Students. Journal of Career Development, v. 39, p. 461-475, 2012.

DONAHUE, Michael J.; BENSON, Peter L. Religion and the well-being of adolescents. Journal of Social Issues, v. 51, n. 2, p. 145-160, 1995.

DRAGO, F. Self-Esteem and Earnings. Institute for the Study of Labor (IZA), 2008.

DUCKWORTH, A., ALMLUND, M, HECKMAN, J. e KAULTZ, T . Personality psychology and Economics. IZA Discussion Paper 5500, 2011.

DUNCAN, Greg J.; BROOKS-GUNN, Jeanne. Family poverty, welfare reform, and child development. Child Development, v. 71, n. 1, p. 188-196, 2000.

DURLAK, J.A.; WEISSBERG, R.P.; DYMNICKI, A.B.; TAYLOR, R.D.; SCHELLINGER, K.B. The impact of enhancing students' social and emotional learning: A meta-analysis of school-based universal interventions. Child Development, v. 82, p. 405-432, 2011.

EBSTYNE KING, Pamela; FURROW, James L. Religion as a resource for positive youth development: religion, social capital, and moral outcomes. In: Meeting of the Society for Research in Child Development, Apr, 2001, Minneapolis, MN, US; A previous version of this article was presented at the aforementioned conference. Educational Publishing Foundation, 2008. p. 34. 
ELIAS, M.; ZINS, J. E.; WEISSBERG, R. P.; FREY, K. S.; GREENBERG, M. T.; HAYNES, N. M.; KESSLER, R., SCHWAB-STONE, M.E., SHRIVER, T.P. Promoting social and emotional learning: A guide for educators. Alexandria, VA: Association for Supervision and Curriculum Development, 1997.

ELLIOTT, S. N.; GRESHAM, F. M.; FREEMAN, T.; MCCLOSKEY, G. Teacher and observer ratings of children's social skills: Validation of the Social Skills Rating Scales. Journal of Psychoeducational Assessment, 6, 152-161, 1988.

ELSE-QUEST, Nicole M. et al. Gender differences in temperament: a metaanalysis. Psychological bulletin, v. 132, n. 1, p. 33, 2006.

ERTMER, Peggy A.; NEWBY, Timothy J. The expert learner: Strategic, self-regulated, and reflective. Instructional Science, v. 24, n. 1, p. 1-24, 1996.

EVANS, Gary W. et al. The role of chaos in poverty and children's socioemotional adjustment. Psychological science, v. 16, n. 7, p. 560-565, 2005.

FASTRÉ, Greet MJ et al. Towards an integrated model for developing sustainable assessment skills. Assessment \& Evaluation in Higher Education, v. 38, n. 5, p. 611-630, 2013.

FEINGOLD, Alan. Gender differences in personality: a meta-analysis. Psychological Bulletin, v. 116, n. 3, p. 429, 1994.

FLOURI, Eirini. Parental interest in children's education, children's self-esteem and locus of control, and later educational attainment: Twenty-six year follow-up of the 1970 British Birth Cohort. British Journal of Educational Psychology, v. 76, n. 1, p. 41-55, 2006.

FOX, Robert A.; PLATZ, Donald L.; BENTLEY, Kathleen S. Maternal factors related to parenting practices, developmental expectations, and perceptions of child behavior problems. The Journal of Genetic Psychology, v. 156, n. 4, p. 431-441, 1995.

FRANKL, Viktor E. Em busca de sentido: um psicólogo no campo de concentração. Editora Sinodal, 2013.

FROSSARD, A. Deus existe, eu encontrei-O. Editor A Esfera dos Livros, 2010.

GARNER, Pamela W. et al. Promoting desirable outcomes among culturally and ethnically diverse children in social emotional learning programs: A multilevel heuristic model. Educational Psychology Review, v. 26, n. 1, p. 165-189, 2014. 
GLANVILLE, Jennifer L.; SIKKINK, David; HERNANDEZ, Edwin I. Religious involvement and educational outcomes: The role of social capital and extracurricular participation. The Sociological Quarterly, v. 49, n. 1, p. 105-137, 2008.

GOLEMAN, D.; BOYATZIS, R.; MCKEE, A. Primal leadership: Realizing the power of emotional intelligence. Boston: Harvard Business School Press, 2002.

GREENBERG, M. T., WEISSBERG, R. P., O'BRIEN, M. U., ZINS, J. E., FREDERICKS, L., RESNIK, H., \& ELIAS, M. J. Enhancing school-based prevention and youth development through coordinated social, emotional, and academic learning. American Psychologist, v. 58, n. 6-7, p. 466, 2003.

GROLNICK, Wendy S.; SLOWIACZEK, Maria L. Parents' involvement in children's schooling: A multidimensional conceptualization and motivational model. Child Development, v. 65, n. 1, p. 237-252, 1994.

GUTHRIE, John T. et al. From spark to fire: Can situational reading interest lead to long-term reading motivation? Literacy Research and Instruction, v. 45, n. 2, p. 91-117, 2005.

GUTHRIE, John T.; MCCRAE, Angela; KLAUDA, Susan Lutz. Contributions of conceptoriented reading instruction to knowledge about interventions for motivations in reading. Educational Psychologist, v. 42, n. 4, p. 237-250, 2007.

HANUSHEK, E.A.; WOESSMANN, L. The role of cognitive skills in economic development. Journal of Economic Literature, v. 46, p. 607-668, 2008.

HECKMAN, J. J. Policies to foster human capital. Research in economics, v. 54, n. 1, p. 3$56,2000$.

HECKMAN, J.J.; RUBINSTEIN, Y. The benefits of skill: The importance of noncognitive skills: Lessons from the GED testing program. American Economic Review, v. 91, p. 145154, 2001.

HECKMAN, J.J.; STIXRUD, J.; URZUA, S. The effects of cognitive and noncognitive abilities on labor market outcomes and social behavior. Journal of Labor Economics, v. 24, p. 411-482, 2006

HECKMAN, James J. Schools, skills, and synapses. Economic Inquiry, v. 46, n. 3, p. 289$324,2008$.

HROMEK, R.; ROFFEY, S. Promoting Social and Emotional Learning With Games "It's Fun and We Learn Things". Simulation \& Gaming, v. 40, n. 5, p. 626-644, 2009. 
HUMMER, Robert A. et al. Does parental religious involvement affect the birth outcomes and health status of young children? In: Annual meetings of the Population Association of America, Atlanta, May. 2002. p. 9-11.

JACOB, Brian A. Where the boys aren't: Non-cognitive skills, returns to school and the gender gap in higher education. Economics of Education Review, v. 21, n. 6, p. 589-598, 2002.

JACOBS, Janis E. et al. Changes in children's self-competence and values: Gender and domain differences across grades one through twelve. Child Development, v. 73, n. 2, p. 509-527, 2002.

JOHN, O. P.; SRIVASTAVA, S. The Big Five Trait Taxonomy: History, Measurement and Theoretical Perspectives. In: Handbook of Personality: Theory and Research. L. A. Pervin and O. P. John, eds. New York, The Guilford Press: p. 102-138, 1999.

JORNAL NACIONAL. Apresentado por William Bonner e Renata Vasconcellos. Rio de Janeiro: Rede Globo, 25 jun. 2016. Disponível em http://g1.globo.com/jornalnacional/edicoes/2016/06/25.htm\#!v/5121061?utm_source=email\&utm_medium=share-bardesktop\&utm_campaign $=$ share-bar

JUDGE, T. A.; LOCKE, E. A.; DURHAM, C. C. The dispositional causes of job satisfaction: A core evaluations approach. Research in Organizational Behavior, v. 19, p. 151-188, 1997.

JUDGE, T. A., HIGGINS, C. A., THORESEN, C. J., BARRICK, M. R. The big five personality traits, general mental ability, and career success across the life span. Personnel Psychology, v. 52, n. 3, p. 621-652, 1999.

KING, Pamela Ebstyne. Religion and identity: The role of ideological, social, and spiritual contexts. Applied Developmental Science, v. 7, n. 3, p. 197-204, 2003.

KING, Pamela Ebstyne. Spirituality as fertile ground for positive youth development. Positive youth development and spirituality: From theory to research, p. 55-73, 2008.

KING, Pamela Ebstyne; BOYATZIS, Chris J. Religious and Spiritual Development. Handbook of Child Psychology and Developmental Science, 2015.

KITANO, H. L. Validity of the Children's Manifest Anxiety Scale and the modified revised California Inventory. Child Development, v. 31, p. 67-72, 1960. 
KRAAYKAMP, Gerbert; VAN EIJCK, Koen. Personality, media preferences, and cultural participation. Personality and Individual Differences, v. 38, n. 7, p. 1675-1688, 2005.

KROK, Dariusz. Religiousness, spirituality, and coping with stress among late adolescents: A meaning-making perspective. Journal of Adolescence, v. 45, p. 196-203, 2015.

LLANO CIFUENTES, Rafael. Deus e o Sentido da Vida. São Paulo: Ed. Marques Saraiva, 2001.

LEE, W. O. Education and $21^{\text {st }}$ century competencies. Keynote paper presented at the Education and $21^{\text {st }}$ Century Competencies, hosted by the Ministry of Education, Oman, 2013.

LUTHANS, F.; AVOLIO, B.J.; AVEY, J.B.; NORMAN, S.M. Positive psychological capital: Measurement and relationship with performance and satisfaction. Personnel Psychology, v. 60, p. 541-572, 2007.

MAEL, Fred A. Single-sex and coeducational schooling: Relationships to socioemotional and academic development. Review of Educational Research, v. 68, n. 2, p. 101-129, 1998.

MAYER, J.D., CARUSO, D.; SALOVEY, P. Emotional intelligence meets traditional standards for an intelligence. Intelligence, v. 27, n.4, 267-298, 1999.

MCCRAE, Robert R.; COSTA, Paul T. Emerging lives, enduring dispositions. Little, Brown and Co., 1984.

MCGREW, K.S. Beyond IQ: A Model of Academic Competence and Motivation (Institute for Applied Psychometrics), 2007. http://www.iapsych.com/acmcewok/map.htm

MCLOYD, Vonnie C. Socioeconomic disadvantage and child development. American Psychologist, v. 53, n. 2, p. 185, 1998.

MULLER, Chandra; ELLISON, Christopher G. Religious involvement, social capital, and adolescents' academic progress: Evidence from the National Education Longitudinal Study of 1988. Sociological Focus, v. 34, n. 2, p. 155-183, 2001.

MURNANE, R. J.; WILLETT, J. B.; LEVY, F. The Growing Importance of Cognitive Skills in Wage Determination. Review of Economics and Statistics, v. 77, p. 251-266, 1995.

NEAL, Derek. The Effects of Catholic Secondary Schooling on Educational Achievement. Journal of Labor Economics, v. 15, n. 1 Part 1, p. 98-123, 1997. 
NEITZEL, Carin; DOPKINS STRIGHT, Anne. Parenting behaviours during child problem solving: The roles of child temperament, mother education and personality, and the problemsolving context. International Journal of Behavioral Development, v. 28, n. 2, p. 166-179, 2004.

NG, Thomas WH; SORENSEN, Kelly L.; EBY, Lillian T. Locus of control at work: a metaanalysis. Journal of Organizational Behavior, v. 27, n. 8, p. 1057-1087, 2006.

OCDE, 2011a. Pisa em Foco $n^{0}$ 5. Como alguns estudantes superam as dificuldades do ambiente socioeconômico? Disponível em http:/www.oecd.org/pisa/ pisaproducts/ pisainfocus/ 48488626.pdf Acesso em 28-01-2016.

OCDE, 2011b. Pisa em Foco $\mathrm{n}^{\mathrm{o}}$ 2. Melhorando o desempenho a partir dos níveis mais baixos. Disponível em http://www.oecd.org/pisa/pisaproducts/pisainfocus/48488426.pdf . Acesso em 28-01-2016.

OCDE 2014a. Education and Social Progress. Disponível em http://educacaosec21.org.br/ biblioteca-3/artigos-e-teses/ . Acesso em 03 de abril de 2014.

OCDE 2014b. Sumário: Fórum de Ministros. Fórum Internacional de Políticas Públicas “Educar para as competências do século 21”. São Paulo, 24 e 25 Março de 2014. Disponível em http://www.educacaosec21.org.br/foruminternacional2014/wp-content/uploads /2014/01/SummaryPolicyMakersESPForum2014-PORT_v2.pdf. Acesso em 03 de abril de 2014.

OCDE, 2015c. Country note for Brazil. Education at a glance. Disponível em http://www.oecd.org/brazil/Education-at-a-glance-2015-Brazil-in-Portuguese.pdf.

OCDE, 2015d. Pisa em Foco $n^{0}$ 49. O que está por trás da desigualdade de gênero na educação? Disponível em http://www.oecd.org/pisa/pisaproducts/pisainfocus/PIF-49\%20 (por).pdf. Acesso em 29-01-2016

OLIVER, Pamella H.; GUERIN, Diana Wright; COFFMAN, Jacqueline K. Big five parental personality traits, parenting behaviors, and adolescent behavior problems: A mediation model. Personality and Individual Differences, v. 47, n. 6, p. 631-636, 2009.

PARK, H.; BEHRMAN, J. R.; CHOI, J. Causal effects of single-sex schools on college entrance exams and college attendance: Random assignment in Seoul high schools. Demography, v. 50, n. 2, p. 447-469, 2013

PATERSON, Colin; CHAPMAN, Judith. Enhancing skills of critical reflection to evidence learning in professional practice. Physical Therapy in Sport, v. 14, n. 3, p. 133-138, 2013. 
PETERSON, C.; SELIGMAN, M. E. P. Character strengths and virtues: A handbook and classification. New York: Oxford University Press, 2004.

POMERANTZ, E.; MOORMAN, A.; LITWACK, S. D. The How, Whom, and Why of Parents' Involvement in Children's Academic Lives: More Is Not Always Better. Review of Educational Research, v. 77, n. 3, p. 373-410, 2007.

PRIMI, R. Inteligência: avanços nos modelos teóricos e nos instrumentos de medida. Avaliação Psicológica, v. 2, n. 1, p. 67-77, 2003.

REGNERUS, Mark D. Religion and positive adolescent outcomes: A review of research and theory. Review of Religious Research, p. 394-413, 2003.

REGNERUS, Mark D. Shaping schooling success: Religious socialization and educational outcomes in metropolitan public schools. Journal for the Scientific Study of Religion, v. 39, n. 3, p. 363-370, 2000.

REGNERUS, Mark D.; ELDER JR, Glen H. Staying on track in school: Religious influences in high-and low-risk settings. Journal for the Scientific Study of Religion, p. 633-649, 2003.

ROBERTS, B., K. Walton e VIECHTBAUER, W. Patterns of Mean-Level Change in Personality Traits across the Life Course: A Meta-Analysis of Longitudinal Studies. Psychological Bulletin 132(1): 1-25, 2006.

ROSENBERG, M. Society and the adolescent self-image. Princeton: Princeton University Press, 1965.

ROTTER, J. B. Generalized Expectancies for Internal Versus External Control of Reinforcement. Psychological Monographs: General and Applied, v. 80, p. 1-28, 1966.

SALOVEY, P., MAYER, J.D. Emotional Intelligence. Imagination, cognition and personality, v. 9, n.3, p. 182-211, 1990.

SANTOS, D. D. A importância socioeconômica das características de Personalidade. Apresentação no Fórum Internacional de Políticas Públicas "Educar para as competências do século 21". São Paulo, 24 e 25 Março de 2014. Disponível em http://educacaosec21.org.br/ biblioteca-3/artigos-e-teses/. Acesso em 03 de abril de 2014.

SANTOS, D. D.; PRIMI, R. Desenvolvimento socioemocional e aprendizado escolar: uma proposta de mensuração para apoiar políticas públicas. Apresentação no Fórum Internacional de Políticas Públicas "Educar para as competências do século 21". São Paulo, 24 e 25 Março de 2014. Disponível http://educacaosec21.org.br/biblioteca-3/artigos-e-teses 
SCHMITT, David P. et al. Why can't a man be more like a woman? Sex differences in Big Five personality traits across 55 cultures. Journal of Personality and Social Psychology, v. 94, n. 1, p. 168, 2008.

SELIGMAN, M.E.P., CSIKSZENTMIHALYI, M. Positive psychology: An introduction. American Psychologist, v. 55, p. 5-14, 2000.

SHEPPERD, James A.; MILLER, Wendi A.; SMITH, Colin Tucker. Religiousness and aggression in adolescents: The mediating roles of self-control and compassion. Aggressive Behavior, v. 41, n. 6, p. 608-621, 2015.

SMITH, Christian. Theorizing religious effects among American adolescents. Journal for the Scientific Study of Religion, v. 42, n. 1, p. 17-30, 2003.

STEELE-JOHNSON, D.; NARAYAN, A.; STEINKE, J. Academic attitudes and their antecedents. Journal of Applied Social Psychology, v. 43, p. 498-506, 2013.

THE NEW YORK TIMES, 2015. Overcoming the Confidence Gap for Women. http:/www.nytimes.com/2015/06/13/business/dealbook/overcoming-the-confidence-gap-forwomen.html?_r=0, acesso em 05-02-2016.

UNESCO. Youth and Skills: Putting Education to Work, EFA Global Monitoring Report, 2012, disponível em http://unesdoc.unesco.org/images/0021/002180/218003e.pdf . Acesso em 10 mai. 2014.

U.S. DEPARTMENT OF EDUCATION, Office of Planning, Evaluation and Policy Development, Policy and Program Studies Service, Single-Sex Versus Secondary Schooling: A Systematic Review, Washington, D.C., 2005. Disponível em http://files. eric.ed.gov/fulltext/ED526944.pdf .

U.S. DEPARTMENT OF EDUCATION, Office of Planning, Evaluation and Policy Development, Policy and Program Studies Service, Early Implementation of Public SingleSex Schools: Perceptions and Characteristics, Washington, D.C., 2008. Disponível em http://files.eric.ed.gov/fulltext/ED504174.pdf

VAN DIJK, Teun Adrianus; KINTSCH, Walter; VAN DIJK, Teun Adrianus. Strategies of discourse comprehension. New York: Academic Press, 1983.

VON STUMM, Sophie; HELL, Benedikt; CHAMORRO-PREZUMIC, Tomas. The hungry mind intellectual curiosity is the third pillar of academic performance. Perspectives on Psychological Science, v. 6, n 6, p. 574-288, 2011. 
WAITE, Linda J.; LEHRER, Evelyn L. The benefits from marriage and religion in the United States: A comparative analysis. Population and Development Review, v. 29, n. 2, p. 255275, 2003.

WANG, Kurt; SABIA, Joseph J; CESUR, Resul. Sleepwalking through school: new evidence on sleep and academic performance. Institute for the Study of Labor (IZA) (N' 9829), 2016.

WELSH, J.A.; NIX, R.L.; BLAIR, C.; BIERMAN, K.L.; NELSON, K.E. The Development of Cognitive Skills and Gains in Academic School Readiness for Children From Low-Income Families. Journal of Educational Psychology, v. 102, p. 43-53, 2010.

WILGENBUSCH, Tammy; MERRELL, Kenneth W. Gender differences in self-concept among children and adolescents: A meta-analysis of multidimensional studies. School Psychology Quarterly, v. 14, n. 2, p. 101, 1999.

YONKER, Julie E.; SCHNABELRAUCH, Chelsea A.; DEHAAN, Laura G. The relationship between spirituality and religiosity on psychological outcomes in adolescents and emerging adults: A meta-analytic review. Journal of Adolescence, v. 35, n. 2, p. 299-314, 2012. 


\section{APÊNDICE}

\section{APÊNDICE A - ESTIMATIVAS DOS EFEITOS DO CONTEXTO DA RELIGIOSIDADE NAS HABILIDADES SOCIOEMOCIONAIS DE ALUNOS SEGUNDO O MODELO LONGO}

Tabela 13. Estimativa dos efeitos do contexto de religiosidade nas habilidades socioemocionais - amostra total de alunos

\begin{tabular}{lccccc}
\hline $\begin{array}{c}\text { Habilidade } \\
\text { Socioemocional }\end{array}$ & Coeficiente & $\begin{array}{c}\text { Erro } \\
\text { padrão }\end{array}$ & P-Valor & N & $\begin{array}{c}\text { R } \\
\text { Quadrado }\end{array}$ \\
\hline Conscienciosidade & 0,038 & 0,021 & 0,069 & 11660 & 0,068 \\
Extroversão & 0,019 & 0,021 & 0,359 & 11661 & 0,035 \\
Estabilidade Emocional & $-0,001$ & 0,020 & 0,971 & 11660 & 0,109 \\
Amabilidade & 0,034 & 0,021 & 0,099 & 11659 & 0,040 \\
Abertura a Experiências & 0,062 & 0,021 & 0,003 & 11661 & 0,087 \\
Lócus de Controle & 0,055 & 0,020 & 0,007 & 11660 & 0,037 \\
Autoconfiança & 0,054 & 0,022 & 0,013 & 11565 & 0,024 \\
Autoestima & 0,044 & 0,021 & 0,041 & 11344 & 0,031 \\
Reflexão & 0,076 & 0,022 & 0,000 & 11492 & 0,049 \\
\hline
\end{tabular}

Fonte: Elaboração própria com uso de dados do Censo Escolar, Prova Brasil e microdados da pesquisa de campo realizada na rede estadual do Rio de Janeiro.

Tabela 14. Estimativa dos efeitos do contexto de religiosidade nas habilidades socioemocionais - alunos com baixa escolaridade materna

\begin{tabular}{lccccc}
\hline $\begin{array}{c}\text { Habilidade } \\
\text { Socioemocional }\end{array}$ & Coeficiente & $\begin{array}{c}\text { Erro } \\
\text { padrão }\end{array}$ & P-Valor & N & $\begin{array}{c}\text { R } \\
\text { Quadrado }\end{array}$ \\
\hline Conscienciosidade & 0,151 & 0,039 & 0,000 & 3181 & 0,061 \\
Extroversão & 0,067 & 0,039 & 0,089 & 3182 & 0,035 \\
Estabilidade Emocional & 0,057 & 0,039 & 0,144 & 3181 & 0,105 \\
Amabilidade & 0,059 & 0,039 & 0,136 & 3182 & 0,036 \\
Abertura a Experiências & 0,101 & 0,040 & 0,013 & 3182 & 0,075 \\
Lócus de Controle & 0,110 & 0,038 & 0,003 & 3182 & 0,035 \\
Autoconfiança & 0,125 & 0,044 & 0,004 & 3152 & 0,017 \\
Autoestima & 0,102 & 0,041 & 0,012 & 3100 & 0,033 \\
Reflexão & 0,099 & 0,042 & 0,018 & 3137 & 0,046 \\
\hline
\end{tabular}

Fonte: Elaboração própria com uso de dados do Censo Escolar, Prova Brasil e microdados da pesquisa de campo realizada na rede estadual do Rio de Janeiro. 
Tabela 15. Estimativa dos efeitos do contexto de religiosidade nas habilidades socioemocionais - alunos com alta escolaridade materna

\begin{tabular}{lccccc}
\hline $\begin{array}{c}\text { Habilidade } \\
\text { Socioemocional }\end{array}$ & Coeficiente & $\begin{array}{c}\text { Erro } \\
\text { padrão }\end{array}$ & P-Valor & N & $\begin{array}{c}\text { R } \\
\text { Quadrado }\end{array}$ \\
\hline Conscienciosidade & $-0,008$ & 0,033 & 0,801 & 4842 & 0,065 \\
Extroversão & 0,012 & 0,034 & 0,712 & 4842 & 0,033 \\
Estabilidade Emocional & $-0,022$ & 0,033 & 0,508 & 4842 & 0,111 \\
Amabilidade & 0,030 & 0,033 & 0,362 & 4842 & 0,039 \\
Abertura a Experiências & 0,065 & 0,033 & 0,050 & 4842 & 0,073 \\
Lócus de Controle & 0,043 & 0,032 & 0,181 & 4842 & 0,038 \\
Autoconfiança & 0,062 & 0,034 & 0,064 & 4808 & 0,021 \\
Autoestima & 0,016 & 0,034 & 0,636 & 4723 & 0,028 \\
Reflexão & 0,096 & 0,034 & 0,004 & 4771 & 0,048 \\
\hline
\end{tabular}

Fonte: Elaboração própria com uso de dados do Censo Escolar, Prova Brasil e microdados da pesquisa de campo realizada na rede estadual do Rio de Janeiro.

Tabela 16. Estimativa dos efeitos do contexto de religiosidade nas habilidades socioemocionais - alunos com pais sem frequência de leitura

\begin{tabular}{lccccc}
\hline $\begin{array}{c}\text { Habilidade } \\
\text { Socioemocional }\end{array}$ & Coeficiente & $\begin{array}{c}\text { Erro } \\
\text { padrão }\end{array}$ & P-Valor & N & $\begin{array}{c}\text { R } \\
\text { Quadrado }\end{array}$ \\
\hline Conscienciosidade & 0,122 & 0,045 & 0,006 & 2505 & 0,081 \\
Extroversão & 0,054 & 0,047 & 0,254 & 2505 & 0,038 \\
Estabilidade Emocional & $-0,002$ & 0,045 & 0,971 & 2505 & 0,114 \\
Amabilidade & 0,044 & 0,046 & 0,331 & 2504 & 0,052 \\
Abertura a Experiências & 0,121 & 0,044 & 0,006 & 2505 & 0,094 \\
Lócus de Controle & 0,072 & 0,046 & 0,111 & 2504 & 0,041 \\
Autoconfiança & 0,129 & 0,050 & 0,010 & 2486 & 0,028 \\
Autoestima & 0,055 & 0,050 & 0,267 & 2431 & 0,035 \\
Reflexão & 0,154 & 0,048 & 0,001 & 2464 & 0,052 \\
\hline
\end{tabular}

Fonte: Elaboração própria com uso de dados do Censo Escolar, Prova Brasil e microdados da pesquisa de campo realizada na rede estadual do Rio de Janeiro. 
Tabela 17. Estimativa dos efeitos do contexto de religiosidade nas habilidades socioemocionais - alunos com pais com frequência de leitura

\begin{tabular}{lccccc}
\hline $\begin{array}{c}\text { Habilidade } \\
\text { Socioemocional }\end{array}$ & Coeficiente & $\begin{array}{c}\text { Erro } \\
\text { padrão }\end{array}$ & P-Valor & N & $\begin{array}{c}\text { R } \\
\text { Quadrado }\end{array}$ \\
\hline Conscienciosidade & 0,018 & 0,023 & 0,431 & 9155 & 0,049 \\
Extroversão & 0,008 & 0,023 & 0,734 & 9156 & 0,029 \\
Estabilidade Emocional & 0,000 & 0,023 & 0,988 & 9155 & 0,099 \\
Amabilidade & 0,033 & 0,023 & 0,159 & 9155 & 0,036 \\
Abertura a Experiências & 0,049 & 0,024 & 0,039 & 9156 & 0,071 \\
Lócus de Controle & 0,052 & 0,023 & 0,020 & 9156 & 0,030 \\
Autoconfiança & 0,033 & 0,024 & 0,168 & 9079 & 0,019 \\
Autoestima & 0,041 & 0,024 & 0,080 & 8913 & 0,025 \\
Reflexão & 0,056 & 0,024 & 0,021 & 9028 & 0,042 \\
\hline
\end{tabular}

Fonte: Elaboração própria com uso de dados do Censo Escolar, Prova Brasil e microdados da pesquisa de campo realizada na rede estadual do Rio de Janeiro.

Tabela 18. Estimativa dos efeitos do contexto de religiosidade nas habilidades socioemocionais - alunos sem incentivo de pais

\begin{tabular}{lccccc}
\hline $\begin{array}{c}\text { Habilidade } \\
\text { Socioemocional }\end{array}$ & Coeficiente & $\begin{array}{c}\text { Erro } \\
\text { padrão }\end{array}$ & P-Valor & N & $\begin{array}{c}\mathbf{R} \\
\text { Quadrado }\end{array}$ \\
\hline Conscienciosidade & 0,118 & 0,050 & 0,017 & 1954 & 0,061 \\
Extroversão & 0,045 & 0,053 & 0,397 & 1954 & 0,047 \\
Estabilidade Emocional & 0,011 & 0,051 & 0,823 & 1954 & 0,116 \\
Amabilidade & $-0,004$ & 0,054 & 0,947 & 1952 & 0,035 \\
Abertura a Experiências & 0,049 & 0,053 & 0,357 & 1954 & 0,098 \\
Lócus de Controle & 0,140 & 0,050 & 0,005 & 1953 & 0,036 \\
Autoconfiança & 0,044 & 0,054 & 0,412 & 1940 & 0,030 \\
Autoestima & 0,114 & 0,058 & 0,050 & 1908 & 0,029 \\
Reflexão & 0,062 & 0,056 & 0,267 & 1926 & 0,060 \\
\hline
\end{tabular}

Fonte: Elaboração própria com uso de dados do Censo Escolar, Prova Brasil e microdados da pesquisa de campo realizada na rede estadual do Rio de Janeiro. 
Tabela 19. Estimativa dos efeitos do contexto de religiosidade nas habilidades socioemocionais - alunos com incentivo de pais

\begin{tabular}{lccccc}
\hline $\begin{array}{c}\text { Habilidade } \\
\text { Socioemocional }\end{array}$ & Coeficiente & $\begin{array}{c}\text { Erro } \\
\text { padrão }\end{array}$ & P-Valor & N & $\begin{array}{c}\mathbf{R} \\
\text { Quadrado }\end{array}$ \\
\hline Conscienciosidade & 0,023 & 0,023 & 0,306 & 9706 & 0,040 \\
Extroversão & 0,016 & 0,023 & 0,481 & 9707 & 0,028 \\
Estabilidade Emocional & $-0,002$ & 0,022 & 0,917 & 9706 & 0,106 \\
Amabilidade & 0,045 & 0,022 & 0,046 & 9707 & 0,029 \\
Abertura a Experiências & 0,065 & 0,023 & 0,004 & 9707 & 0,072 \\
Lócus de Controle & 0,038 & 0,022 & 0,084 & 9707 & 0,030 \\
Autoconfiança & 0,056 & 0,024 & 0,020 & 9625 & 0,023 \\
Autoestima & 0,031 & 0,023 & 0,181 & 9436 & 0,020 \\
Reflexão & 0,077 & 0,024 & 0,001 & 9566 & 0,039 \\
\hline
\end{tabular}

Fonte: Elaboração própria com uso de dados do Censo Escolar, Prova Brasil e microdados da pesquisa de campo realizada na rede estadual do Rio de Janeiro.

Tabela 20. Estimativa dos efeitos do contexto de religiosidade nas habilidades socioemocionais - alunos com baixa escolaridade materna: meninos

\begin{tabular}{lccccc}
\hline $\begin{array}{c}\text { Habilidade } \\
\text { Socioemocional }\end{array}$ & Coeficiente & $\begin{array}{c}\text { Erro } \\
\text { padrão }\end{array}$ & P-Valor & N & $\begin{array}{c}\text { R } \\
\text { Quadrado }\end{array}$ \\
\hline Conscienciosidade & 0,195 & 0,062 & 0,002 & 1157 & 0,069 \\
Extroversão & 0,168 & 0,063 & 0,008 & 1157 & 0,043 \\
Estabilidade Emocional & $-0,015$ & 0,057 & 0,799 & 1157 & 0,033 \\
Amabilidade & 0,096 & 0,065 & 0,141 & 1157 & 0,039 \\
Abertura a Experiências & 0,152 & 0,068 & 0,025 & 1157 & 0,075 \\
Lócus de Controle & 0,108 & 0,057 & 0,057 & 1157 & 0,044 \\
Autoconfiança & 0,093 & 0,068 & 0,171 & 1147 & 0,026 \\
Autoestima & 0,094 & 0,062 & 0,131 & 1129 & 0,050 \\
Reflexão & 0,189 & 0,069 & 0,006 & 1141 & 0,055 \\
\hline
\end{tabular}

Fonte: Elaboração própria com uso de dados do Censo Escolar, Prova Brasil e microdados da pesquisa de campo realizada na rede estadual do Rio de Janeiro. 
Tabela 21. Estimativa dos efeitos do contexto de religiosidade nas habilidades socioemocionais - alunos com baixa escolaridade materna: meninas

\begin{tabular}{lccccc}
\hline $\begin{array}{c}\text { Habilidade } \\
\text { Socioemocional }\end{array}$ & Coeficiente & $\begin{array}{c}\text { Erro } \\
\text { padrão }\end{array}$ & P-Valor & N & $\begin{array}{c}\mathbf{R} \\
\text { Quadrado }\end{array}$ \\
\hline Conscienciosidade & 0,138 & 0,051 & 0,006 & 2024 & 0,054 \\
Extroversão & 0,009 & 0,050 & 0,857 & 2025 & 0,033 \\
Estabilidade Emocional & 0,114 & 0,053 & 0,031 & 2024 & 0,028 \\
Amabilidade & 0,042 & 0,050 & 0,405 & 2025 & 0,037 \\
Abertura a Experiências & 0,068 & 0,050 & 0,174 & 2025 & 0,085 \\
Lócus de Controle & 0,120 & 0,050 & 0,016 & 2025 & 0,041 \\
Autoconfiança & 0,157 & 0,057 & 0,006 & 2005 & 0,021 \\
Autoestima & 0,117 & 0,054 & 0,031 & 1971 & 0,037 \\
Reflexão & 0,037 & 0,053 & 0,487 & 1996 & 0,054 \\
\hline
\end{tabular}

Fonte: Elaboração própria com uso de dados do Censo Escolar, Prova Brasil e microdados da pesquisa de campo realizada na rede estadual do Rio de Janeiro.

Tabela 22. Estimativa dos efeitos do contexto de religiosidade nas habilidades socioemocionais de alunos com dummy de 3 vulnerabilidades = 1 (baixa escolaridade materna, pais sem frequência de leitura e sem incentivo de pais)

\begin{tabular}{lccccc}
\hline $\begin{array}{c}\text { Habilidade } \\
\text { Socioemocional }\end{array}$ & Coeficiente & $\begin{array}{c}\text { Erro } \\
\text { padrão }\end{array}$ & P-Valor & N & $\begin{array}{c}\text { R } \\
\text { Quadrado }\end{array}$ \\
\hline Conscienciosidade & 0,280 & 0,113 & 0,014 & 339 & 0,126 \\
Extroversão & 0,081 & 0,127 & 0,524 & 339 & 0,051 \\
Estabilidade Emocional & 0,154 & 0,124 & 0,215 & 339 & 0,142 \\
Amabilidade & 0,062 & 0,119 & 0,604 & 339 & 0,117 \\
Abertura a Experiências & 0,190 & 0,128 & 0,138 & 339 & 0,132 \\
Lócus de Controle & 0,336 & 0,124 & 0,007 & 339 & 0,163 \\
Autoconfiança & 0,283 & 0,142 & 0,046 & 337 & 0,084 \\
Autoestima & 0,156 & 0,145 & 0,285 & 329 & 0,102 \\
Reflexão & 0,161 & 0,138 & 0,243 & 332 & 0,092 \\
\hline
\end{tabular}

Fonte: Elaboração própria com uso de dados do Censo Escolar, Prova Brasil e microdados da pesquisa de campo realizada na rede estadual do Rio de Janeiro. 
Tabela 23. Estimativa dos efeitos do contexto de religiosidade nas habilidades socioemocionais de alunos com dummy de 3 vulnerabilidades $=0$ (baixa escolaridade materna, pais sem frequência de leitura e sem incentivo de pais)

\begin{tabular}{lccccc}
\hline $\begin{array}{c}\text { Habilidade } \\
\text { Socioemocional }\end{array}$ & Coeficiente & $\begin{array}{c}\text { Erro } \\
\text { padrão }\end{array}$ & P-Valor & N & $\begin{array}{c}\mathbf{R} \\
\text { Quadrado }\end{array}$ \\
\hline Conscienciosidade & 0,040 & 0,023 & 0,080 & 9813 & 0,061 \\
Extroversão & 0,008 & 0,023 & 0,711 & 9814 & 0,029 \\
Estabilidade Emocional & 0,002 & 0,022 & 0,919 & 9813 & 0,107 \\
Amabilidade & 0,035 & 0,023 & 0,123 & 9814 & 0,035 \\
Abertura a Experiências & 0,059 & 0,023 & 0,009 & 9814 & 0,074 \\
Lócus de Controle & 0,039 & 0,022 & 0,077 & 9814 & 0,034 \\
Autoconfiança & 0,058 & 0,024 & 0,015 & 9733 & 0,017 \\
Autoestima & 0,042 & 0,023 & 0,067 & 9562 & 0,028 \\
Reflexão & 0,074 & 0,023 & 0,002 & 9674 & 0,041 \\
\hline
\end{tabular}

Fonte: Elaboração própria com uso de dados do Censo Escolar, Prova Brasil e microdados da pesquisa de campo realizada na rede estadual do Rio de Janeiro. 